Prepared in cooperation with Benton Conservation District under Washington Department of Ecology Funding Agreement WRYBP-VER1-BentCD-00004 as part of the Yakima Basin Integrated Plan

\title{
Thermal Heterogeneity and Cold-Water Anomalies within the Lower Yakima River, Yakima and Benton Counties, Washington
}

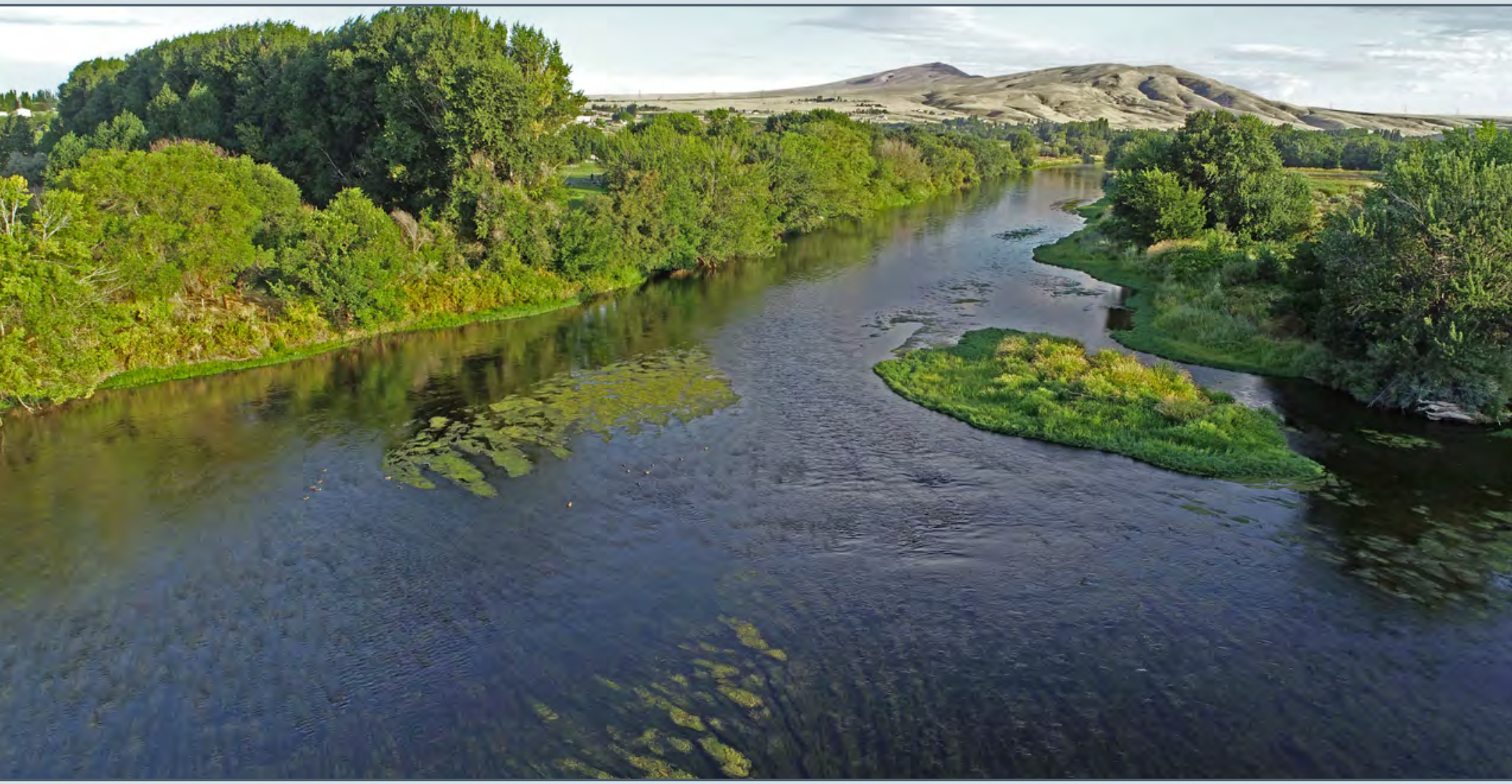

Scientific Investigations Report 2021-5140 
Cover: Songbird Island, Yakima River near Benton City, Benton County, Washington. Photograph by Stephen Ingalls, Benton County Mosquito Control Board, May 1, 2020. Used with permission. 


\section{Thermal Heterogeneity and Cold-Water Anomalies within the Lower Yakima River, Yakima and Benton Counties, Washington}

By Andrew S. Gendaszek and Marcella Appel

Prepared in Cooperation with Benton Conservation District under Washington Department of Ecology Funding Agreement WRYBP-VER1-BentCD-00004 as part of the Yakima Basin Integrated Plan

Scientific Investigations Report 2021-5140 


\section{U.S. Geological Survey, Reston, Virginia: 2021}

For more information on the USGS - the Federal source for science about the Earth, its natural and living resources, natural hazards, and the environment—visit https://www.usgs.gov or call 1-888-ASK-USGS.

For an overview of USGS information products, including maps, imagery, and publications, visit https://store.usgs.gov/.

Any use of trade, firm, or product names is for descriptive purposes only and does not imply endorsement by the U.S. Government.

Although this information product, for the most part, is in the public domain, it also may contain copyrighted materials as noted in the text. Permission to reproduce copyrighted items must be secured from the copyright owner.

Suggested citation:

Gendaszek, A.S., and Appel, M., 2021, Thermal heterogeneity and cold-water anomalies within the lower Yakima River, Yakima and Benton Counties, Washington: U.S. Geological Survey Scientific Investigations Report 2021-5140, 43 p., https://doi.org/10.3133/sir20215140.

ISSN 2328-0328 (online) 


\section{Contents}

Abstract

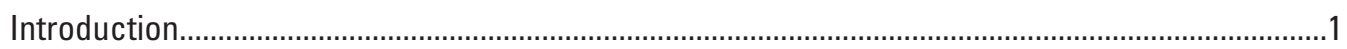

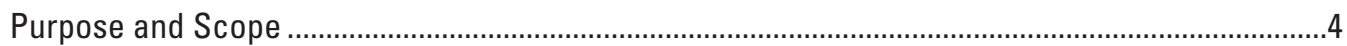

Study Area

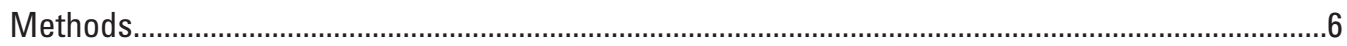

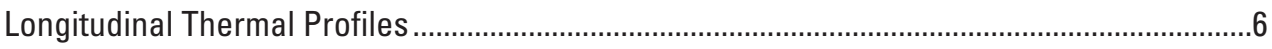

Channel and Floodplain Geomorphic Analysis .......................................................................

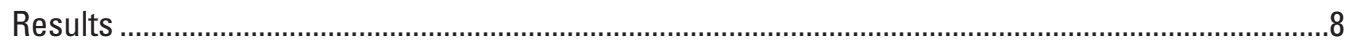

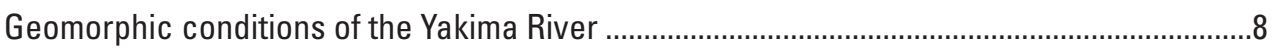

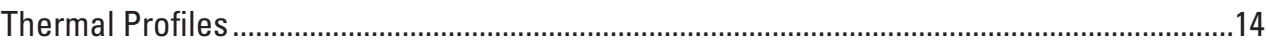

Parker Reach (River Miles 103-92) ................................................................................14

Toppenish Reach (River Miles 92-83).............................................................................17

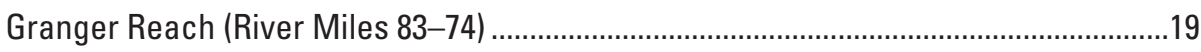

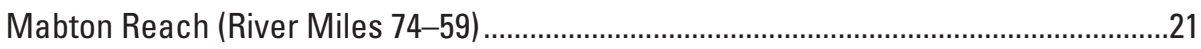

Prosser Reach (River Miles 47-36) .........................................................................24

Chandler Reach (River Miles 36-30) ...........................................................................25

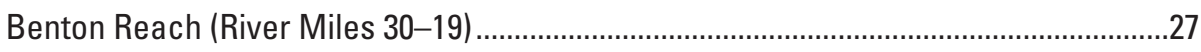

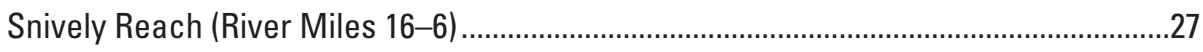

Confluence Reach (River Miles 9-0) .........................................................................34

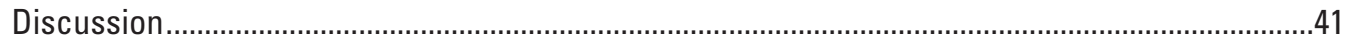

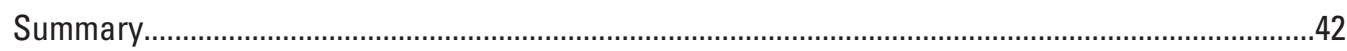

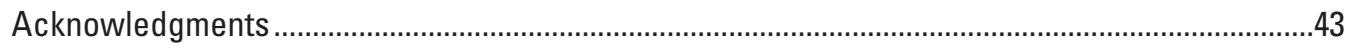

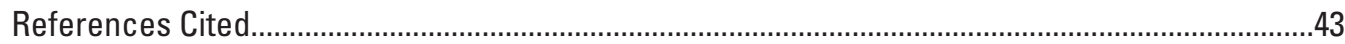

\section{Figures}

1. Map showing location of the Yakima River in central Washington .....................................3

2. Maps showing locations of study reaches in the lower Yakima River study area between Sunnyside diversion dam and Mabton and Prosser diversion dam and the confluence of the Columbia and Yakima Rivers, Washington ......................................5

3. Graphs showing longitudinal profiles of water-surface elevation and gradient of the lower Yakima River, Washington, June 2015........................................................9

4. Graph showing longitudinal profile of mean wetted channel width of the lower Yakima River, Washington, July 2015..........................................................................

5. Map showing relative elevation surface model of the floodplain between river miles 100 and 95, Yakima River, Washington..................................................................10

6. Map showing relative elevation surface model of the floodplain between river miles 58 and 53, Yakima River, Washington.

7. Map showing relative elevation surface model of the floodplain between river miles 25 and 20, Yakima River, Washington.

8. Graphs showing longitudinal profiles of water-surface elevation and gradient derived from river miles 58-53 of the Yakima River, Washington, May-June 2015.........13

9. Graphs showing longitudinal profiles of water-surface elevation and gradient between river miles 100 and 95 of the Yakima River, Washington, May-June 2015 .......16 
10. Graphs showing thermal profiles of channel center collected August 28, 2001 and September 13, 2001, Parker Reach, Yakima River, Washington.....

11. Graphs showing thermal profiles and detrended temperature change, since the start of survey, of channel left and channel right, Parker Reach, Yakima River, June 28, 2018

12. Graph showing thermal profile of channel center, Toppenish Reach, Washington, September 14, 2001

13. Graphs showing thermal profiles and detrended temperature change, since the start of survey, of channel left and channel right, Toppenish Reach, Yakima River, Washington, June 5, 2018.

14. Graph showing thermal profile of the channel center of Granger Reach, Yakima River, Washington, August 30, 2001

15. Graphs showing thermal profiles and detrended temperature change, since the start of survey, of channel left, channel center, and channel right, Granger Reach, Yakima River, Washington, July 12, 2018

16. Graphs showing thermal profiles and detrended temperature change, since the start of survey, of channel left, channel center, and channel right, Mabton Reach, Yakima River, Washington, August 17, 2018.

17. Graph showing thermal profile of Prosser Reach, Yakima River, Washington, August 30, 2002

18. Graphs showing thermal profile of channel left and channel right, Prosser Reach, Yakima River, Washington, September 3, 2008.

19. Graphs showing thermal profiles and detrended temperature change of channel left, Prosser Reach, Yakima River, Washington, July 27, 2009...

20. Graphs showing thermal profiles and rate of water-temperature change of channel left and channel right, Prosser Reach, Yakima River, Washington, September 13, 2018.

21. Graph showing thermal profiles of channel center of Chandler Reach, Yakima River, Washington, August 19, 2008

22. Graphs showing thermal profiles and detrended temperature change, since the start of survey, of channel left $(A$ and $B)$, channel center $(C$ and $D)$, and channel right ( $E$ and $F$, Chandler Reach, Yakima River, Washington, July 28, 2009

23. Graphs showing thermal profiles and detrended temperature change, since the start of survey, of channel left, channel center, and channel right, Chandler Reach, Yakima River, July 18, 2018.

24. Graphs showing thermal profiles of channel left, channel center, and channel right, Benton Reach, Yakima River, Washington, August 12, 2008.

25. Graphs showing thermal profiles and detrended temperature change, since the start of survey, of channel left $(A$ and $B)$, channel center $(C$ and $D)$, and channel right ( $E$ and $F$, Benton Reach, Yakima River, Washington, July 29, 2009

26. Graphs showing thermal profiles and detrended temperature change, since the start of survey, of channel left, channel center, and channel right, Benton Reach, Yakima River, Washington, July 27, 2018

27. Graphs showing longitudinal profiles of water-surface elevation and gradient between river miles 25 and 20, Yakima River, Washington, May-June 2015

28. Thermal profiles of channel left, channel center, and channel right, Snively Reach, Yakima River, Washington, August 13, 2008.

29. Thermal profiles and detrended temperature change, since the start of survey, of channel left, channel center, and channel right, Yakima River, Washington, July 30,2009 
30. Thermal profiles and detrended temperature change, since the start of survey, of channel left, channel center, and channel right, Snively Reach, Yakima River, Washington, July 19, 2018.

31. Thermal profiles of channel left $(A)$, channel center $(B)$, and channel right $(C)$, Confluence Reach, Yakima River, August 14, 2008

32. Thermal profiles and detrended temperature change, since the start of survey, of channel left, channel center, and channel right, Confluence Reach, Yakima River, Washington, July 31, 2009

33. Thermal profiles and detrended temperature change, since the start of survey, of channel right, channel center, and channel left, Confluence Reach, Yakima River, Washington, July 20, 2018

\section{Table}

1. Summary of thermal profiles surveyed between 2001 and 2018, lower Yakima River, Washington.

U.S. customary units to International System of Units

\begin{tabular}{|c|c|c|}
\hline Multiply & By & To obtain \\
\hline \multicolumn{3}{|c|}{ Length } \\
\hline inch (in.) & 2.54 & centimeter $(\mathrm{cm})$ \\
\hline foot $(\mathrm{ft})$ & 0.3048 & meter $(\mathrm{m})$ \\
\hline \multicolumn{3}{|c|}{ Area } \\
\hline square mile $\left(\mathrm{mi}^{2}\right)$ & 2.590 & square kilometer $\left(\mathrm{km}^{2}\right)$ \\
\hline \multicolumn{3}{|c|}{ Flow rate } \\
\hline cubic foot per second $\left(\mathrm{ft}^{3} / \mathrm{s}\right)$ & 0.02832 & cubic meter per second $\left(\mathrm{m}^{3} / \mathrm{s}\right)$ \\
\hline
\end{tabular}

International System of Units to U.S. customary units

\begin{tabular}{|c|c|c|}
\hline Multiply & By & To obtain \\
\hline \multicolumn{3}{|c|}{ Length } \\
\hline centimeter $(\mathrm{cm})$ & 0.3937 & inch (in.) \\
\hline meter (m) & 3.281 & foot (ft.) \\
\hline \multicolumn{3}{|c|}{ Area } \\
\hline square kilometer $\left(\mathrm{km}^{2}\right)$ & 0.3861 & square mile $\left(\mathrm{mi}^{2}\right)$ \\
\hline \multicolumn{3}{|c|}{ Flow rate } \\
\hline cubic meter per second $\left(\mathrm{m}^{3} / \mathrm{s}\right)$ & 35.31 & cubic foot per second $\left(\mathrm{ft}^{3} / \mathrm{s}\right)$ \\
\hline
\end{tabular}

Temperature in degrees Celsius $\left({ }^{\circ} \mathrm{C}\right)$ may be converted to degrees Fahrenheit $\left({ }^{\circ} \mathrm{F}\right)$ as ${ }^{\circ} \mathrm{F}=\left(1.8 \times{ }^{\circ} \mathrm{C}\right)+32$. 



\title{
Thermal Heterogeneity and Cold-Water Anomalies within the Lower Yakima River, Yakima and Benton Counties, Washington
}

\author{
By Andrew S. Gendaszek and Marcella Appel
}

\section{Abstract}

Warm water temperatures in the lower Yakima River in central Washington are key limitations to the restoration of Pacific salmon (Onchorhynchus spp.) populations within the Yakima River Basin. Identification of the location and magnitude of cold-water anomalies, which are cooler than ambient river temperatures during summer months, and the processes that create and maintain them is needed to inform salmon restoration efforts within the Yakima River Basin. Longitudinal thermal profiles of nine reaches in the lower Yakima River were surveyed at ambient river velocity during summer 2018 when surface-water temperatures were near their annual maximum and the difference between surface-water and groundwater temperatures was greatest. The profiles were compared to previously published profiles of the same reaches measured in 2001, 2002, 2008, and 2009, and analyzed in the context of hydrologic, geomorphic, and hydrogeologic conditions that may create and maintain cold-water inputs to the river. Coldwater anomalies that departed from expected diurnal increases in water temperature were measured in all nine study reaches and were attributed to diffuse groundwater discharge through the streambed, discrete groundwater discharge at seeps and springs, and cold-water tributaries entering the river. Some cold-water anomalies were measured during repeated surveys in different years, whereas other cold-water anomalies did not persist across surveys. Additionally, some discrete cold-water anomalies were confined to one side of the channel, but others associated with diffuse groundwater discharge were present across the channel for several river miles. Hydrogeologic conditions including the extent and thickness of aquifers connected to the Yakima River, geomorphic conditions including channel gradient, channel geometry, and floodplain extent, and the location of tributaries, irrigation returns, and other surface-water inputs created the large-scale conditions that facilitate the formation and maintenance of cold-water anomalies. Finer-scale geomorphic features such as side channels, gravel-bar alcoves, deep pools, and other locations, where colder water collected and remained relatively unmixed with upstream surface water, were also important factors in the occurrence and distribution of cold-water anomalies. These hydrogeologic and geomorphic conditions, coupled with the alteration of the Yakima River's hydrologic regime to support irrigation within the Yakima Valley, contributed to the surveyed distribution of cold-water anomalies within the river.

\section{Introduction}

Water temperature controls the metabolic rates of fish and other ectothermic (cold-blooded) species, which have specific thermal tolerances outside of which they are susceptible to infection, disease, decreased reproductive success, and other deleterious effects (McCullough, 1999). Warm water temperatures may also create thermal barriers that fragment a stream network (Isaak and others, 2010) and prevent migration of fish to thermally suitable habitat (Kock and others, 2020). Water temperature varies temporally over diel, seasonal, and interannual timescales as well as spatially across a stream network forcing some species to thermoregulate by migrating to thermally tolerable water within cold-water refuges. These discrete patches of cold water are created and maintained by hydrogeologic, hydrologic, and geomorphic features such as groundwater discharge zones, tributary confluences, and deep pools (Berman and Quinn, 1991; Torgersen and others, 1999).

In the Pacific Northwest, anadromous and resident coldwater fish, including salmon and trout (Oncorhynchus spp.), require cold, oxygenated water during each of their life-history stages. Water temperatures of salmon-bearing rivers of the Pacific Northwest generally reach their thermal maximum during late summer and early autumn and sometimes exceed the thermal tolerances for salmon and trout. Several species of anadromous salmonids migrate upstream to their spawning grounds during late summer and early autumn, when they can encounter water temperatures above their thermal tolerance. As a result, discrete patches of cold water, referred to as cold-water refuges, within the stream network exist where water temperature is maintained within the thermal tolerance of salmonids and become increasingly important to support migrating and holding salmon and trout during periods of thermal stress (Torgersen and others, 2012). These patches of cold water provide refuges for fish to survive in reaches where 
ambient stream temperatures otherwise exceed their thermal tolerances (Sutton and others, 2007). Cold-water refuges useful for fish occur at a range of spatial scales ranging from microhabitat on the scale of a few square meters to entire stream networks within drainage basins exceeding 100 square kilometers $\left(\mathrm{km}^{2}\right)$. Inputs of cold water to a stream may occur as discrete point sources or dispersed non-point sources over a stream segment. A number of processes create and maintain cold-water anomalies including groundwater discharge, cold-water tributaries and irrigation returns, and stratification in pools (Bilby, 1984; Nielsen and others, 1994; Ebersole and others, 2003). Additional information is needed about the use of individual cold-water anomalies by salmonids and other fish to understand their function as cold-water refuges.

Groundwater discharge to streams is an important influence on surface-water temperatures because it is buffered from large daily and seasonal fluctuations in temperature; consequently, groundwater is generally cooler than surface water during the summer and warmer than surface water during the winter. Groundwater discharge, whether through discrete springs and seeps or diffuse inputs, may provide cold-water refuges within stream networks during the summer and conversely zones of relatively warm water during the winter. The temperature of groundwater depends on the rate and temperature of groundwater recharge, land surface temperature, and heat conduction through groundwater flow paths (Burns and others, 2017). The magnitude of the influence of groundwater discharge on instream temperatures relevant to fish and other aquatic species depends on streamflow, the relative differences between groundwater and surface-water temperature, and downstream advective mixing of the two waters (Kurylyk and others, 2015). Locations of groundwater discharge depend on the hydraulic relation between groundwater and surface-water features and the hydraulic properties of underlying aquifers and streambed sediments (Konrad, 2006) as well as geomorphic features of the channel and floodplain (Poole and others, 2006). Some tributaries may not only contribute point inputs of cold surface water to the receiving stream but may also contribute to increased groundwater discharge to the receiving stream at the distal end of alluvial fans within the main river valley (Konrad, 2006). Cold-water refuges may also be present at the bottom of thermally stratified pools where cold-water input from groundwater discharge or hyporheic exchange exceeds mixing with surface water (Nielsen and others, 1994).

In the Yakima River of central Washington (fig. 1), cold-water refuges have been considered by river managers as potentially important elements of the aquatic ecosystem that support the viability of several distinct populations of resident and anadromous salmonids (Appel, 2011). Ambient water temperatures of the lower Yakima River between Union Gap and the confluence of the Yakima River with the Columbia River at Richland have exceeded tolerances for several species of salmonids and influenced the upstream migration of radiotagged sockeye salmon (Kock and others, 2020). The survival of cold-water fish during periods of thermal stress is likely to depend, in part, on the availability of cold-water refuges within the lower Yakima River. Understanding the location, spatial extent, and persistence of cold-water refuges within the Yakima River helps river managers protect and enhance these habitats. The contribution of groundwater discharge and other physical processes to cold-water refuges in the Yakima River and its tributaries has previously been investigated through longitudinal temperature profiles measured in 2001, 2002, 2008, and 2009, groundwater/surface-water gradients measured with mini-piezometers, seepage runs, process-based models, and airborne thermal infrared imagery (Holroyd, 1998; Mastin, 2008; Magirl and others, 2009; Appel, 2011; Vaccaro, 2011; Voss and Maule, 2013; Quantum Spatial, Inc., 2021).

Previous investigations of water temperature and groundwater/surface-water interactions revealed spatial complexity in the thermal regime of the lower Yakima River and the presence of cold-water anomalies that are less than ambient water temperatures and may provide refuge for migrating fish (Vaccaro, 2011; Appel, 2011). Although extensive use of cold-water refuges for thermoregulation of migrating salmonids has been documented elsewhere in the Columbia River Basin (Keefer and others, 2018), a study of tagged migrating sockeye salmon (Onchorhynchus nerka) in the Yakima River revealed minimal use of several known cold-water features (Kock and others, 2020); however, this may in part be due to the lack of functional habitat available at the monitored cold-water features. In order to better understand the impact of water temperature on migrating fish within the Yakima River Basin and to determine the occurrence and distribution of cold-water sources available to them, we evaluated the persistence of known cold-water anomalies and identified additional cold-water anomalies and the processes that contribute to their formation and maintenance. In this report, we interpret longitudinal profiles of near-streambed water temperatures collected in water year (WY) 2018 with regard to previously collected hydrologic data, geomorphic conditions of the Yakima River and its floodplain, and the hydrogeologic framework of the Yakima River Basin developed by Vaccaro and others (2009). Further investigations are warranted to determine the suitability of individual cold-water anomalies identified within this report as functional cold-water refuges for salmonids and other fish. 


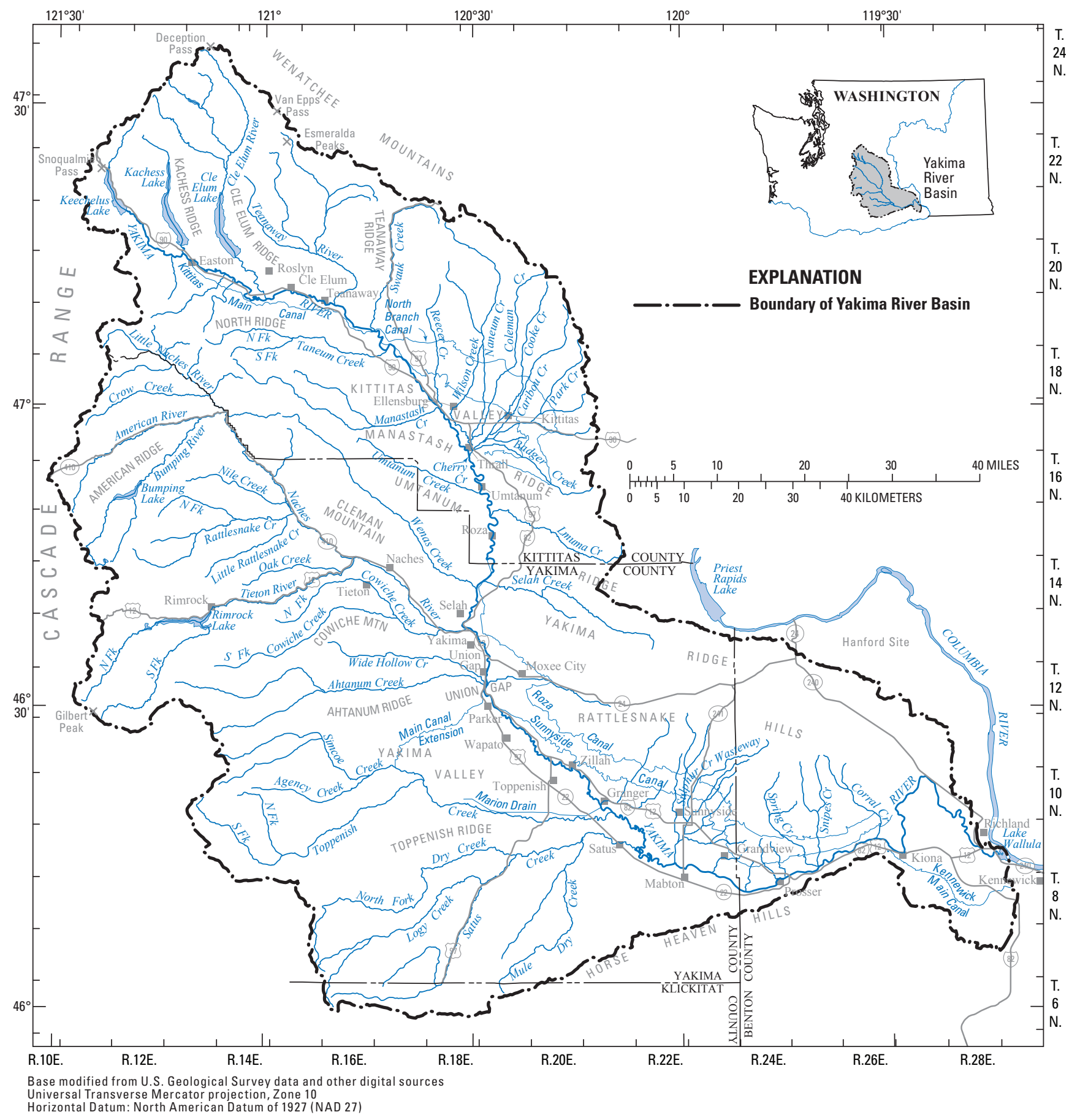

Figure 1. Location of the Yakima River in central Washington. 


\section{Purpose and Scope}

The purpose of this report is to describe the occurrence and distribution of cold-water anomalies in the lower Yakima River, which may serve as refuges for fish and other aquatic biota, and to document the analysis of the hydrologic, hydrogeologic, and geomorphic processes contributing to their formation and maintenance. Whereas cold-water refuges used by cold-water fish are generally defined as waters that are $2{ }^{\circ} \mathrm{C}$ colder than the surrounding water (Environmental Protection Agency, 2003), the cold-water anomalies defined in this study were delineated where near-streambed water temperatures measured along longitudinal profiles at ambient stream velocity deviate from expected diurnal increases recorded by stationary water-temperature sensors. In the study area, solar radiation forms a principal component of the heat flux during clear, sunny summer days (Voss and others, 2008). Nine longitudinal profiles of near-streambed water temperature collected between June and September 2018 in the 103.8 river miles of the Yakima River downstream from the Sunnyside diversion dam to the confluence of the Yakima and Columbia Rivers were compared to previously published profiles measured between 2001 and 2009 (Vaccaro and others, 2008; Appel, 2011; Vaccaro, 2011) and analyzed in the context of hydrologic, geologic, and geomorphic conditions of the Yakima River and its contributing watershed. Profiles measured in 2018 were measured at two to three lateral locations in each reach along the left, center, and right sides of the channel in order to determine the lateral extent of cold-water anomalies within each reach.

\section{Study Area}

The Yakima River, which heads at the outlet of Keechelus Lake near Snoqualmie Pass, drains a 15,939 km² (6,154 square miles $\left[\mathrm{mi}^{2}\right]$ ) area of the eastern slopes of the central Cascade Range of Washington and western margin of the Columbia Plateau before joining the Columbia River at the city of Richland (fig. 1). This study considers nine reaches within the 103.8 river miles of the Yakima River downstream from Sunnyside diversion dam to the confluence of the Yakima and Columbia Rivers within Yakima and Benton Counties, which is referred to in this report as the lower Yakima River study area (fig. 2). River miles upstream from the Yakima/
Columbia River confluence were established from USGS topographic quadrangles and are used as a common reference frame for data presented within the report. Within the study area, the Yakima River flows through the Yakima Valley, the most downstream of a series of broad valleys that are separated by east-west trending anticlinal ridges of the Yakima fold-and-thrust belt. Few perennial tributaries of the Yakima River traverse these ridges, which separate the Yakima Valley from other valleys in the Yakima River Basin from each other including the Kittitas, Naches, and Moxee Valleys. Most of the population, agriculture, and water use within the Yakima River Basin is located within these valleys. The orographic effect of the Cascade Range results in a large precipitationelevation gradient with mean annual precipitation exceeding 304.8 centimeters $(\mathrm{cm})$ (120 inches [in.]) in the high-elevation headwaters, which mostly falls as snow during the winter and melts during the spring freshet, but only $15.2 \mathrm{~cm}(6 \mathrm{in}$.) at the Yakima River's outlet to the Columbia River.

To deliver irrigation water throughout the Yakima River Basin via a network of diversion dams and irrigation canals, the Bureau of Reclamation regulates streamflow of the Yakima River through the operation of dams at the outlets of five reservoirs that retain spring snowmelt. About 124.6 cubic meters per second $\left(\mathrm{m}^{3} / \mathrm{s}\right)\left(4,400\right.$ cubic feet per second $\left.\left[\mathrm{ft}^{3} / \mathrm{s}\right]\right)$ of the Yakima River's streamflow is diverted for irrigation of agricultural crops throughout the basin, and about $48.1 \mathrm{~m}^{3} / \mathrm{s}$ $\left(1,700 \mathrm{ft}^{3} / \mathrm{s}\right)$ recharges back into the shallow groundwater system, which greatly exceeds natural recharge from precipitation in the lower basin (Vaccaro and Olsen, 2007; Vaccaro and others, 2009). Forty-five percent of water diverted for irrigation returns to the Yakima River and its tributaries as surface-water return flow and groundwater discharge (Bureau of Reclamation, 1999) and during low-flow periods accounts for about 75 percent of streamflow in the lower Yakima River (Vaccaro, 2011). Groundwater levels in irrigated parts of the Yakima River Basin fluctuate seasonally as a result of changes in groundwater recharge from irrigation and discharge to streams, rivers, drains, and wasteways (Vaccaro and others, 2009), with the highest groundwater levels at the end of the irrigation season in late August and the lowest groundwater levels at the start of irrigation season between mid-March and early May (Drost and others, 1997). The discharge of groundwater that recharges to surficial aquifers from irrigation constitutes the largest component of streamflow in the Yakima River downstream of the Kittitas Valley to the north and upstream of the study area (Vaccaro, 2011). 

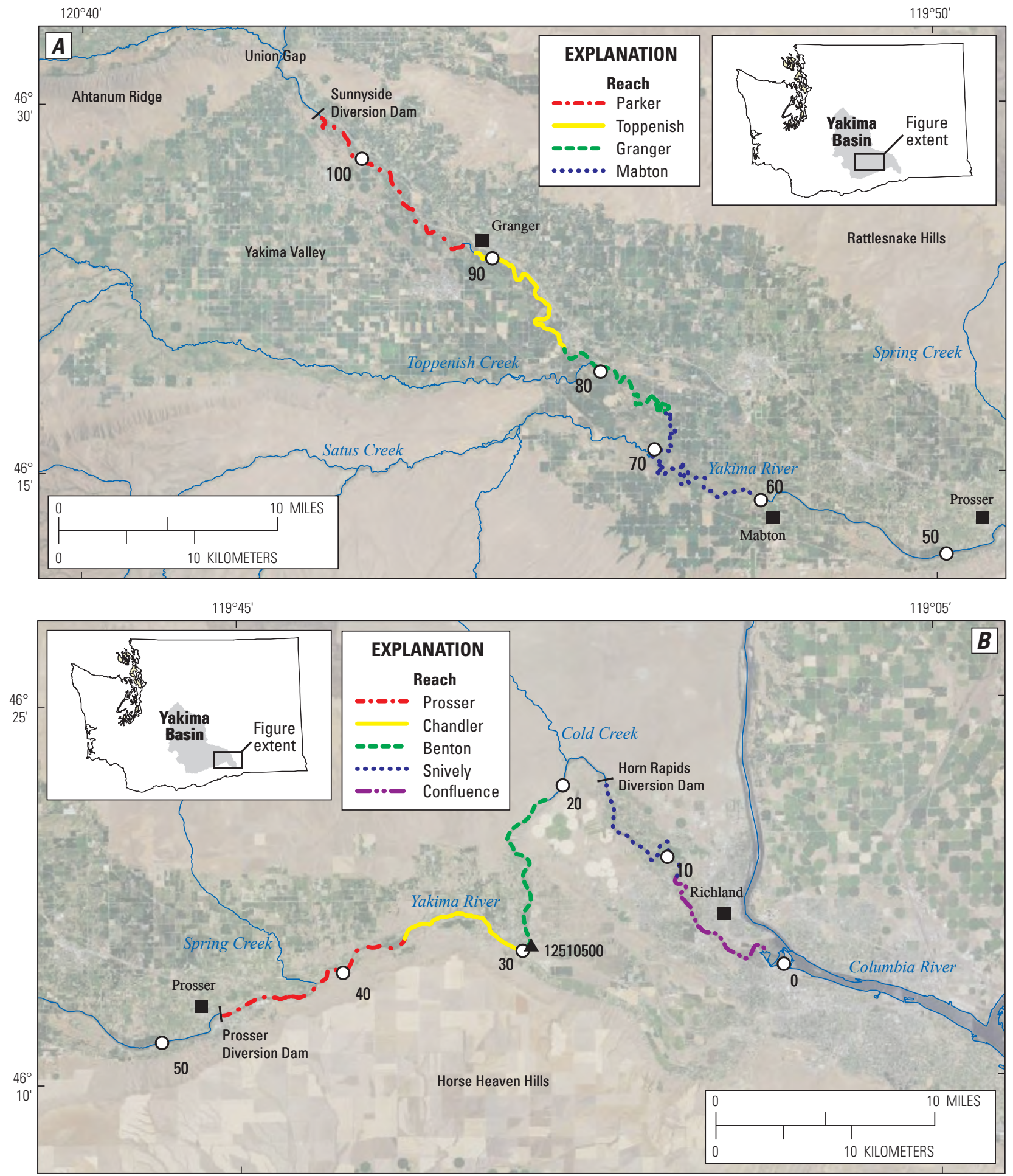

Figure 2. Locations of study reaches in the lower Yakima River study area between Sunnyside diversion dam and Mabton $(A)$ and Prosser diversion dam and the confluence of the Columbia and Yakima Rivers $(B)$, Washington. 
Vaccaro and others (2009) described the hydrogeologic framework of the Yakima River Basin, including the spatial distribution, stratigraphic relations, and hydraulic properties of major hydrogeologic units, as well as the occurrence and movement of groundwater. In the study area, the Yakima River flows across the broad Yakima Valley, which is bordered to the north by Ahtanum Ridge and the Rattlesnake Hills (which are separated by Union Gap) and to the south by Toppenish Ridge and Horse Heaven Hills. These ridges are formed by the southernmost east-west trending anticlines of the Yakima fold-and-thrust belt at the western margin of the Columbia Plateau. The ridges are comprised of a series of basalt flows of the Columbia River Basalt Group (CRBG), which erupted during the Miocene from fissures in eastern Washington, northeastern Oregon, and western Idaho, collectively covering more than $160,000 \mathrm{~km}^{2}\left(61,800 \mathrm{mi}^{2}\right.$; Tolan and others, 1989). Sedimentary units, including the Ellensburg Formation, a volcaniclastic unit sourced from the Cascade Range to the east, underlie, intercalate, and overlie CRBG basalt flows (Jones and others, 2006), and their deposition and preservation were determined by the paleodrainage developed from the concurrent structural evolution of the Yakima fold-and-thrust belt (Smith, 1988). In the Yakima Valley, Jones and others (2006) defined two structural basins that broadly follow synclines bounded by anticlinal ridges into which thick sediments were deposited from the Miocene through the Holocene. In the Toppenish basin to the west of Granger, sediments reach a depth of 366 meters (m) (1,200 feet [ft]) and, in the Benton basin east of Granger, sediments reach a depth of $274 \mathrm{~m}(900$ $\mathrm{ft}$ ). In both basins, volcaniclastic sediments of the Ellensburg Formation comprise the greatest thickness of basin-fill sediments and occur stratigraphically below gravel, sand, and silt deposited by glacial outburst floods and subsequent inundation of the Yakima Valley by Glacial Lake Lewis during the Pleistocene, which include the Touchet Beds, and Holocene alluvium of the Yakima River and its tributaries. Additionally, wind-blown Pleistocene loess was deposited in the Yakima Valley. Collectively, basin-fill sediments provide important sources of groundwater that are used for agricultural irrigation as well as commercial and domestic supply (Jones and others, 2006).

\section{Methods}

\section{Longitudinal Thermal Profiles}

Longitudinal profiles of near-streambed temperature, hereafter referred to as "thermal profiles," were measured in nine reaches of the Yakima River between Sunnyside diversion dam and the confluence of the Yakima and Columbia Rivers between June and September 2018 to determine the occurrence and distribution of cold-water anomalies and characterize groundwater/surface-water exchanges. The nine longitudinal thermal profiles surveyed in 2018 were compared to previously published profiles measured in 2001, 2002, 2008, and 2009 (Vaccaro and others, 2008; Vaccaro, 2011; Appel, 2011). These profiles were analyzed with respect to information about the distribution and magnitude of streamflow gains and losses measured between 1988 and 2006 during seepage runs compiled by Magirl and others (2009), but these data were not measured concurrently with the thermal profiles and hydrologic conditions between the seepage runs and thermal profile surveys may have differed. Thermal profiles were measured moving downstream at ambient river surface velocity in a Lagrangian framework to approximate the transport time of a parcel of water and track changes in its temperature during the diurnal increase of the diel temperature fluctuation (Vaccaro and Maloy, 2006). In the Yakima River, departures from the diurnal increase in temperature may be attributed to advective components of the heat flux such as groundwater discharge and surface-water inflows as well as changes in riparian vegetation shading that alter solar radiative inputs (Vaccaro and Maloy, 2006; Vaccaro, 2011). During the 2018 surveys, water temperature was also measured by a stationary temperature probe located at the upstream end of each reach in order to analyze departures from diurnal heating of river water recorded by thermal profiles measured at ambient velocity. Temperature was also measured at stationary locations for previously published thermal profiles collected in 2009, but not in 2001, 2002, or 2008. At seven of the nine reaches, three thermal profiles were measured in the center of the channel, along the right side of the channel, and along the left side of the channel in order to capture cold-water influences that occur at the channel margins, like bank seeps and alcoves associated with point bars, that occur on only one side of the channel. At two reaches, thermal profiles were obtained at two lateral positions at the right and left sides of the channel but not at the center due to equipment failure in the Parker Reach and logistical constraints in the Prosser Reaches.

Near-streambed water temperature was measured at 3 -second intervals using a Solinst Levelogger LT temperature probe that was encased in protective housing weighted to remain in constant contact with the streambed. A five-point calibration check of each temperature probe, which has a reported accuracy of $0.05{ }^{\circ} \mathrm{C}$, was performed between temperatures of 4 and $40{ }^{\circ} \mathrm{C}$ before and after thermal-profile surveys using a National Institute of Standards and Technology (NIST) certified thermistor. Additionally, field checks of thermistors were performed before and after each profile using a NISTcertified thermistor. Water temperatures were recorded by each temperature probe as it was towed by a canoe or raft floating downstream at ambient stream velocity and the coordinates of each measurement were concurrently measured using a Garmin ${ }^{\circledR}$ GPSmap ${ }^{\circledR} 60$ Csx global positioning system (GPS), which had a reported horizontal accuracy of $3 \mathrm{~m}$ at 3 -second intervals and related to water temperature measured at the same time. The GPS was located in about $3 \mathrm{~m}$ of the temperature probe throughout the survey. If GPS coordinates were missing for time steps when temperature data were collected, linear interpolation between adjacent surveyed points was 
used to determine the position of water-temperature data. Temperature data were deleted from the near-streambed watertemperature profile if downstream progress of survey collection boats was interrupted. Additionally, the channel-right and channel-left profiles deviated at times from the main channel to measure the temperature at the side channels, alcoves downstream of point bars, and inlets of surface-water features.

Discrete and diffuse cold-water anomalies were determined from detrended longitudinal temperature profiles in which diurnal temperature increases were removed by subtracting water temperature changes measured at a stationary location. Cold-water anomalies were defined as locations within the longitudinal thermal profile where the change in detrended temperature was negative relative to the start of the survey, which indicated that water temperature was cooler than the expected diurnal warming measured at the stationary location. Two types of cold-water anomalies that met this criteria, discrete and diffuse, were distinguished from each other within the profiles based on the longitudinal extent of the anomaly. Discrete cold-water anomalies, which were attributable to a distinct source of cold water such as discharge from a spring or a cold-water tributary, occurred where discharge did not readily mix with ambient water delivered from upstream. As a result, discrete cold-water anomalies were localized in spatial extent and typically larger in magnitude than diffuse cold-water anomalies that were attributed to a diffuse source of cold water such as groundwater seepage distributed over a broad reach that mixed readily with streamflow. Interpretation of detrended longitudinal water-temperature profiles assumed similar heat capacity of the reaches where stationary water-temperature probes were deployed and the longitudinal thermal profile reach. If the heat capacity of the thermal profile reach was higher than the location of the stationary probe due to increased depth, for example, decreases in the detrended temperature profile relative to the start of the survey could be also be attributed to changes in heat capacity in addition to advection of cold water from sources such as groundwater discharge. The sensitivity of detrended thermal profiles to detect cold-water anomalies may also be altered due to changes in heat fluxes within the study reach. Detection of cold-water anomalies is most sensitive when the contrast between surface-water temperatures and cold-water inputs from sources including groundwater and tributaries is greatest. During an individual survey, this contrast increases from the start of the survey in the morning when surface-water temperatures are cool to the end of the survey in the afternoon when surface-water temperatures are warmer; consequently, the sensitivity of the thermal profiles to detect cold-water anomalies increases from the start to the end of the survey. Likewise, seasonal changes in heat fluxes may affect the sensitivity of thermal profiles to detect cold-water anomalies. Thermal profiles presented in this report were collected during the summer between July and August during clear, sunny days to maximize solar radiative inputs during the surveys and maximize the detection of cold-water anomalies.

\section{Channel and Floodplain Geomorphic Analysis}

Planform and longitudinal morphology of the lower Yakima River's channel and floodplain was characterized from high-resolution light detection and ranging (lidar) topographic data and orthoimagery. Changes in planform geometry, including width of the channel and floodplain, and longitudinal changes (for example, elevation and gradient) relative to underlying aquifers have been hypothesized to drive groundwater/surface-water exchanges including streamflow gains and losses by establishing gradients between groundwater and surface water (Konrad, 2006). The discharge of groundwater, which during the summer is typically colder than surface water, into the river may decrease surface-water temperature. Lidar has been previously used to develop water-surface profiles of rivers (Magirl and others, 2005), and digitization of rivers and floodplains from orthoimagery has been used to determine longitudinal changes in planform morphology including changes in channel width (for example, Gendaszek and others, 2012; Lauer and others, 2017). Lidar topographic data of the lower Yakima River surveyed in 2015, including raw point-cloud data and gridded 1-m resolution bare-earth digital elevation model (DEM), were obtained for the lower Yakima River study area (Oregon Department of Geology and Mineral Industries, 2016). Mean absolute vertical error for the 2015 lidar survey was $0.017 \mathrm{~m}$. Reported point density for the 2015 lidar survey averaged 2.63 points per square meter but was lower for the wetted channel (an average of 1.51 points per square meter) because water returns fewer laser pulses. Lidar point density was generally lowest within calm water such as pools, runs, and backwaters of diversion dams and highest within broken water such as riffles, which Magirl and others (2005) attributed to the presence of air bubbles that enhanced lidar reflectance. Orthoimagery of the lower Yakima River and its floodplain collected at 1-m resolution in July 2017 was obtained from the National Agricultural Imagery Program (NAIP; U.S. Department of Agriculture, 2012).

Longitudinal profiles of water-surface elevation and gradient along the centerline of the primary channel of the Yakima River were developed from point clouds of lidar topographic data. The centerline of the Yakima River's primary channel was digitized from the 2015 lidar DEM hillshade, buffered at a lateral distance of $10 \mathrm{~m}$, and the buffered channel centerline was partitioned into 10-m-long sections. This centerline was referenced to Yakima River miles by linear interpolation between the 2015 centerline and the nearest river mile. The mean elevation of topographic points in each $10-\mathrm{m}$ section of the channel centerline $10-\mathrm{m}$ buffer was calculated to develop the longitudinal water-surface profile. A continuous profile of water-surface gradient was calculated over a $1-\mathrm{km}$ moving window for each 10-m section of the Yakima River centerline that had at least $5010-\mathrm{m}$ sections within the 1-km moving window. Lidar of the Yakima River centerline was acquired during 5 days between May 11 and June 18, 2015, when mean daily streamflow of the Yakima River at USGS 
gage 12510500 ranged from 38.8 to $83.0 \mathrm{~m}^{3} / \mathrm{s}(1,370$ to 2,930 $\left.\mathrm{ft}^{3} / \mathrm{s}\right)$. During the survey days, mean daily stage at USGS gage 12510500 varied by $0.43 \mathrm{~m}(1.42 \mathrm{ft})$, but differences in river stage were limited to the boundaries of the flight paths during each survey day. A detailed, independent validation of the accuracy of the lidar-derived water-surface profile was impossible because no concurrent ground-based survey of the water-surface profile was measured. The difference between stage measured at USGS gage 12510500 at the time of the lidar survey and the lidar-derived elevation was $1 \mathrm{~cm}(0.03 \mathrm{ft})$, which was less than the reported absolute mean error for the lidar survey as a whole.

The Yakima River floodplain and channel dimensions were characterized through analysis of lidar topographic data and aerial orthoimagery. Maps of the relative elevation of the floodplain with respect to the 2015 lidar water-surface profile referred to as a relative elevation surface model that detrends the floodplain by the local water-surface elevation (Jones, 2006). These maps were used to visualize channel and floodplain forms that occur near or below the water-surface profile such as side channels, oxbow lakes, scroll bars, gravel bars, and spring brooks. These maps were developed by differencing the 2015 bare-earth lidar DEM from a surface created by extending the 2015 lidar water-surface profile into the floodplain from the 2015 centerline. In order to estimate the Yakima River's wetted width, wetted channel, and centerline of the primary channel were manually digitized from the 2017 NAIP orthoimagery at a 1:5,000 scale. The wetted channel was classified as the portion of the Yakima River and connected side channels that contained water, and the primary channel was classified as the widest part of the wetted channel when multiple channels existed. The centerline was manually digitized as the middle of the primary channel. At the time of the NAIP survey between July 16-22, 2017, the mean daily streamflow of the Yakima River at USGS Gage 12510500 ranged from 33.1 to $34.5 \mathrm{~m}^{3} / \mathrm{s}\left(1,170\right.$ to $\left.1,220 \mathrm{ft}^{3} / \mathrm{s}\right)$. This streamflow was within the range of streamflows, 21.4 to $52.1 \mathrm{~m}^{3} / \mathrm{s}$ (755 to $1,840 \mathrm{ft}^{3} / \mathrm{s}$ ), during the collection of thermal profiles between June 28 and September 13, 2018, but generally less than the streamflows during the lidar surveys. The centerline was divided into $1-\mathrm{km}$ sections, and the area of the wetted channel within each section was calculated. Mean width of each section's wetted channel was calculated by dividing the area of the wetted section by the centerline length. One-kilometer sections were referenced to Yakima River miles by linear interpolation between the 2017 NAIP centerline and the nearest river mile.

\section{Results}

\section{Geomorphic conditions of the Yakima River}

The lower Yakima River is comprised of several geomorphically distinct segments, including an anastomosing segment within a wide alluvial floodplain between the Sunnyside diversion dam at river mile (RM) 103.8 and Mabton (RM 60), a low-gradient, straight segment within a narrow alluvial floodplain between Mabton and Prosser diversion dam (RM 47.1), and a high-gradient, bedrock-controlled segment within a narrow alluvial floodplain between Prosser diversion dam and the confluence of the Yakima and Columbia Rivers (RM 0.0 ; fig. 3). Differences in planform channel and floodplain morphology between these segments are evident from abandoned channels, oxbow lakes, and scroll bars, as revealed by lidar-derived relative elevation surface models. Additionally, these segments are bounded by discontinuities within longitudinal water-surface profiles (elevation and gradient; fig. 3) and wetted channel width of the lower Yakima River (fig.4).

The floodplain and channel of the Yakima River vary in width and complexity throughout the study area depending on the sedimentary deposits and bedrock that underlie the river. The wide, alluvial floodplain of the Yakima River between the Sunnyside diversion dam and Mabton contains multiple relict side channels, oxbow lakes, and scroll bars indicative of high rates of channel migration. In this section of the Yakima River, the width of the floodplain that is less than 2 $\mathrm{m}$ above the Yakima River's water surface is up to $1.6 \mathrm{~km}$ (1 mile) (fig. 5). Mean width of the wetted channel between the Sunnyside diversion dam and Mabton was as low as $25.7 \mathrm{~m}$ and as high as $98.7 \mathrm{~m}$ (fig. 4), though numerous gravel bars were present, indicating a greater extent of the active channel at high flow. The modern floodplain of this segment of the Yakima River is largely bounded by terraces on its left bank to the north, which were formed by the modern Yakima River and Pleistocene glacial outburst flood deposits (Campbell, 1983; Bentley and Campbell, 1993; Schuster, 1994). These sediments comprise the youngest and stratigraphically highest deposits in the Toppenish and Benton basins (Jones and others, 2006; Vaccaro and others, 2009). In contrast, the Yakima River floodplain downstream of Mabton is constrained on both sides by terraces comprised of Touchet Beds and bedrock hillslopes of Saddle Mountains Basalt such that the area less than $2 \mathrm{~m}$ above the water surface is less and largely limited to the wetted channel itself (figs. 6, 7). As a result of terraces constraining both sides of the river, channel migration and the resulting deposition of gravel bars, which are ubiquitous throughout the Yakima River between Sunnyside diversion dam and Mabton, are largely absent downstream. The widest wetted channel was measured within the segment between Mabton and the Prosser diversion dam, reaching an average width of over $170 \mathrm{~m}$ at RM 55 and 57 (fig. 4). 

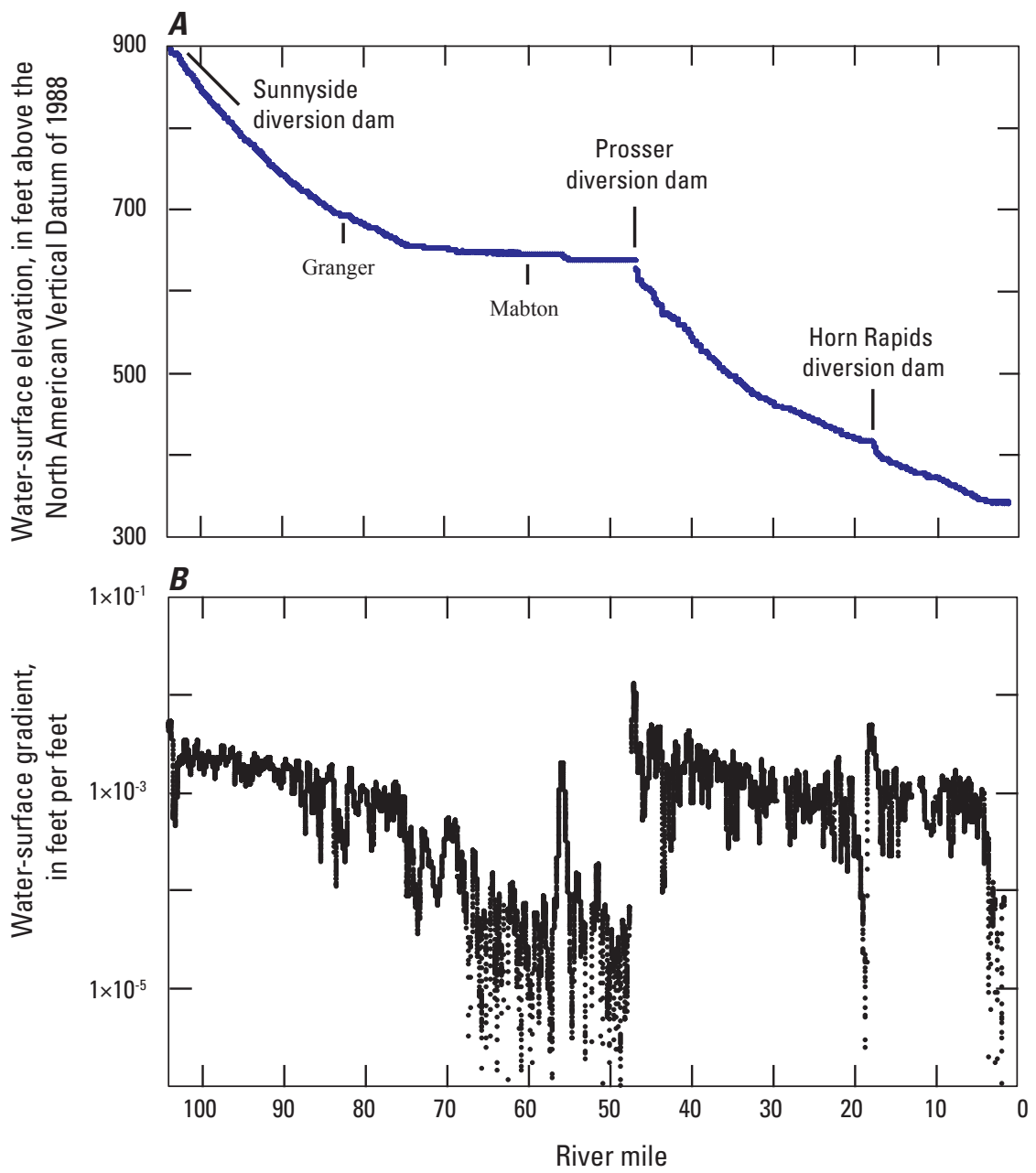

Figure 3. Longitudinal profiles of water-surface elevation and gradient of the lower Yakima River, Washington, June 2015. Profiles derived from lidar imagery.

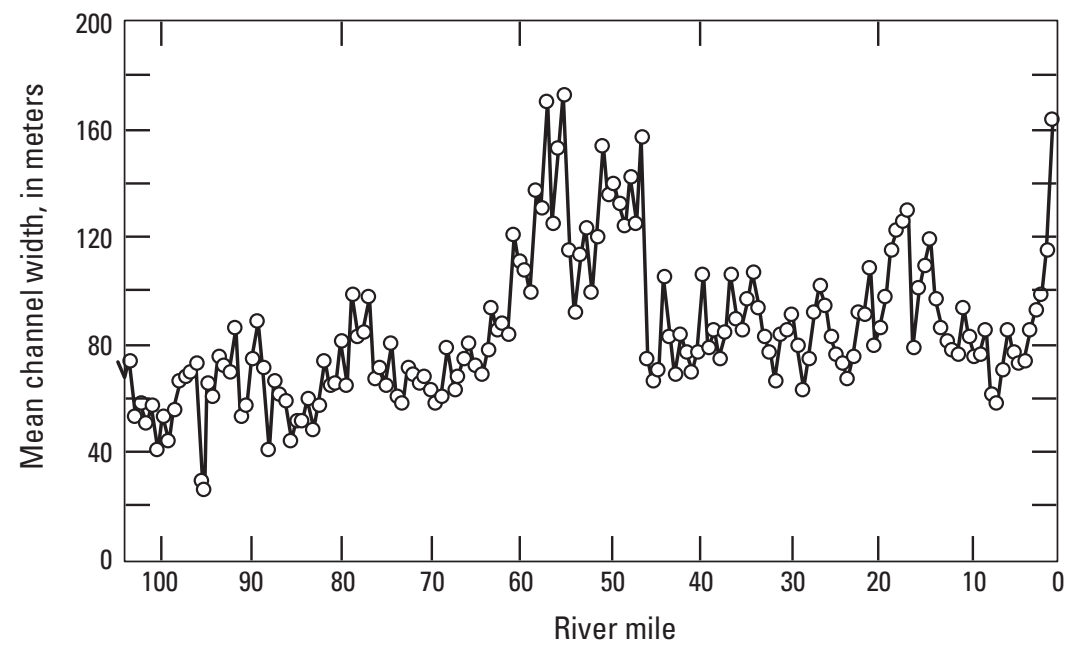

Figure 4. Longitudinal profile of mean wetted channel width of the lower Yakima River, Washington, July 2015. Data derived from lidar orthoimagery. 


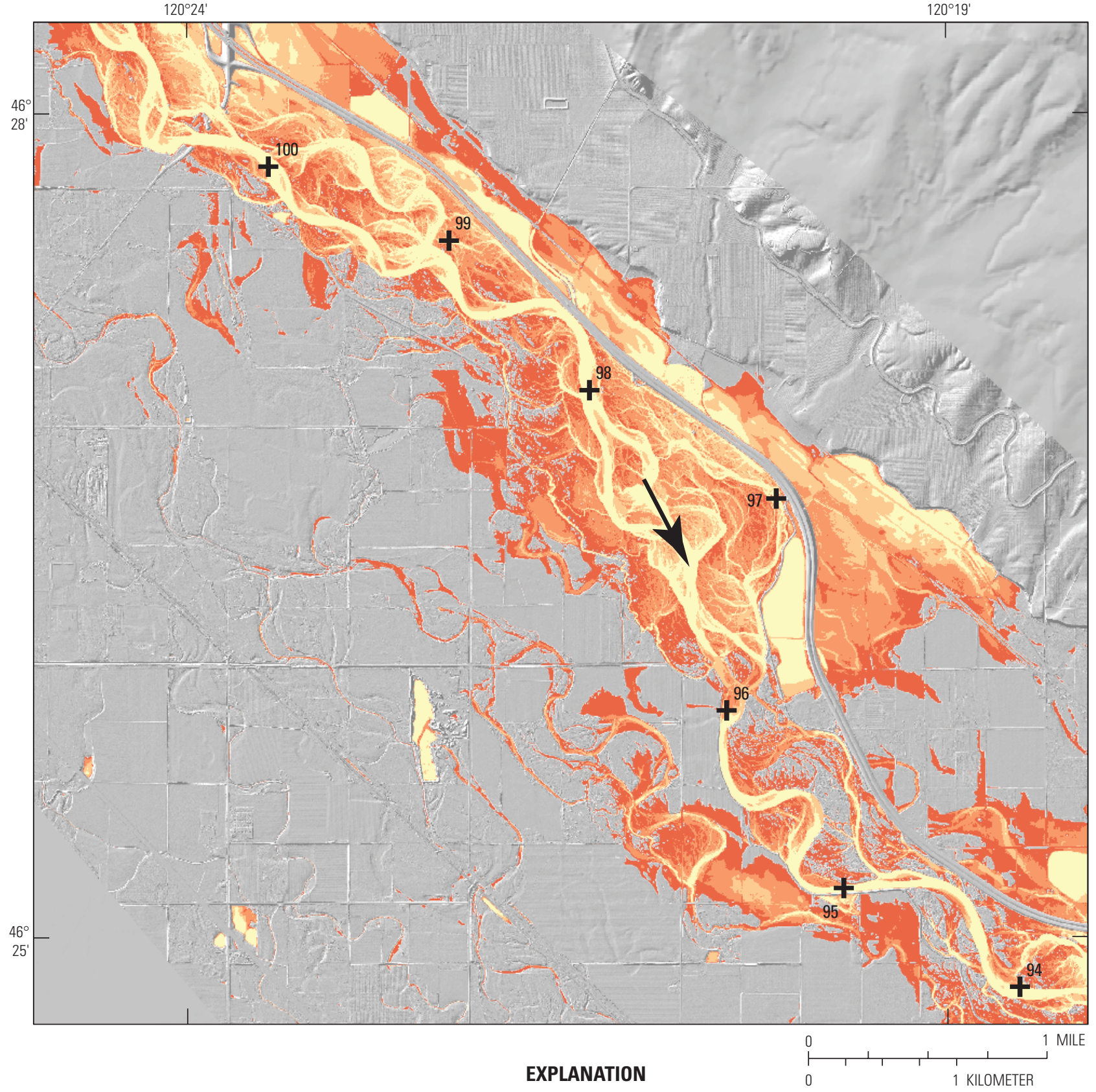

Height above water surface, in meters

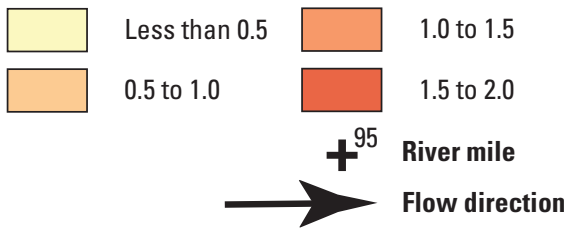

Figure 5. Relative elevation surface model of the floodplain between river miles 100 and 95, Yakima River, Washington. 


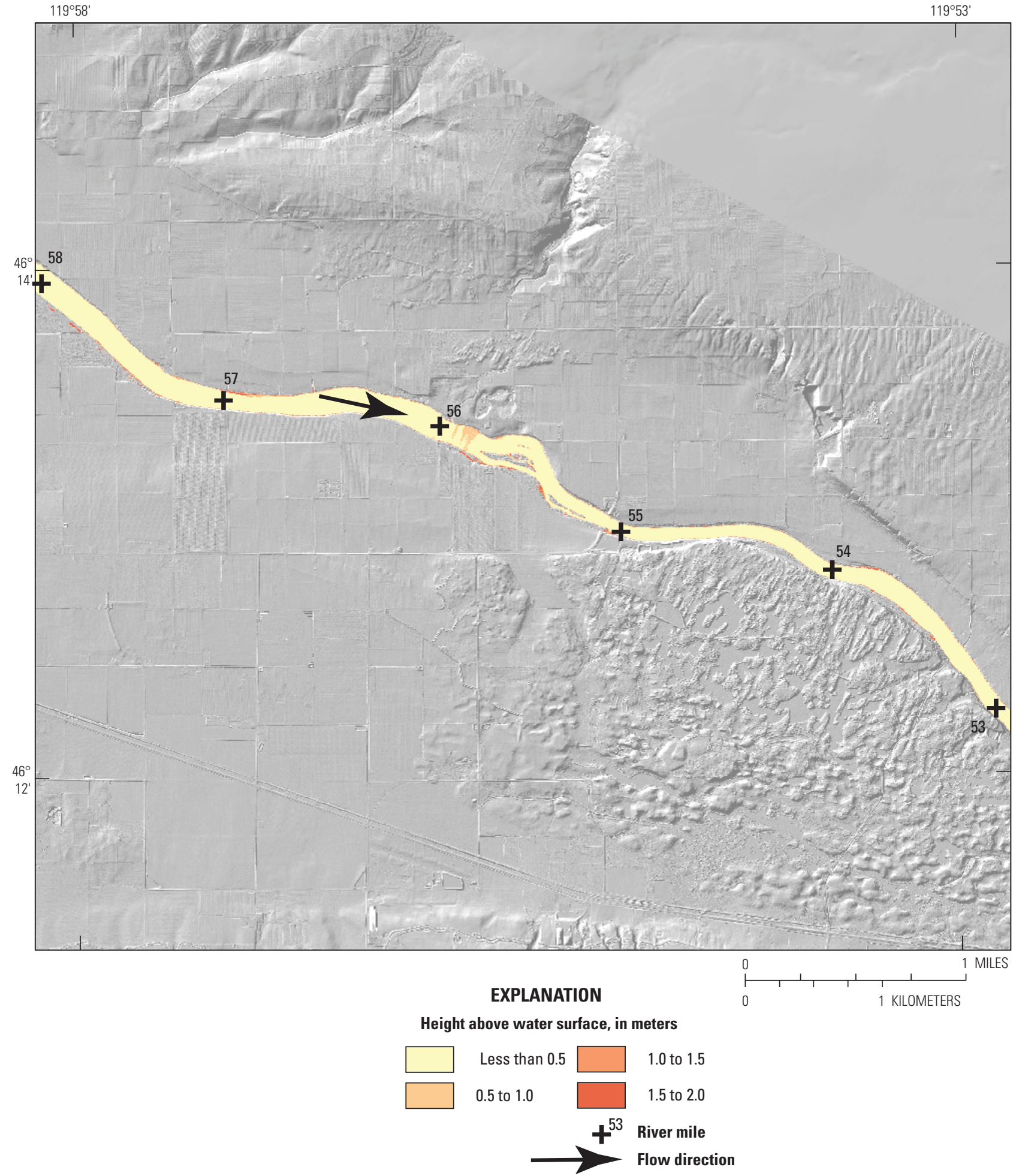

Figure 6. Relative elevation surface model of the floodplain between river miles 58 and 53, Yakima River, Washington. 


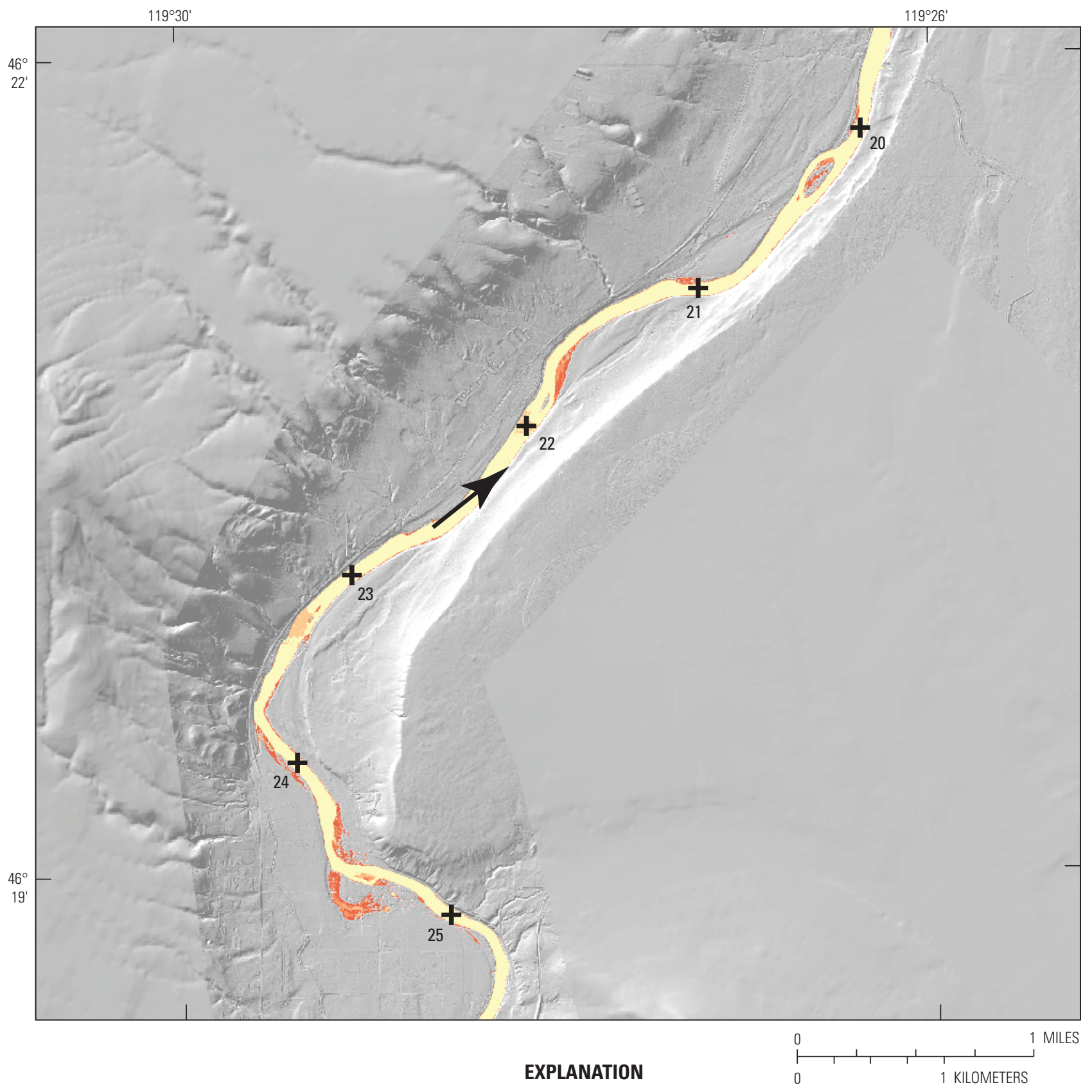

Height above water surface, in meters

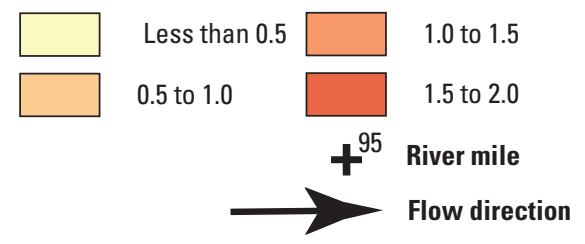

Figure 7. Relative elevation surface model of the floodplain between river miles 25 and 20, Yakima River, Washington. 
Planform geomorphic changes of the Yakima River are accompanied by a break in the longitudinal profile of the water surface at RM 47.1 where the Prosser diversion dam, a 2.7-m-high (9-ft-high) concrete weir, separates the lower Yakima River into two distinct segments with separate convex longitudinal profiles (fig. 3). In the upstream segment of the lower Yakima River from Sunnyside diversion dam to Prosser diversion dam, the water-surface gradient of the convex profile of this segment of the Yakima River increasingly decreases such that the water-surface gradient becomes less than 0.0001 meters per meter $(\mathrm{m} / \mathrm{m})$ downstream of Mabton. Between Mabton and Prosser diversion dam, only one riffle at RM 56.7 is present where bedrock of the Saddle Mountains Basalt crops out adjacent to the Yakima River's channel forming a high-gradient section in an otherwise 30-km (20-mile) low-gradient section of the river (figs. 6, 8). Downstream of the Prosser diversion dam, the Yakima River increases to its highest gradient in the lower Yakima River at the start of a separate convex longitudinal profile between Prosser diversion dam and the confluence of the Yakima and Columbia Rivers. Lateral movement of the Yakima River's channel within this reach is constrained by basalt bedrock of the Saddle Mountains Basalt and Pleistocene glacial outburst flood deposits such that modern alluvium is confined to a narrow riparian corridor. The high gradient of this section of the river decreases at the backwater of the Horn Rapids diversion dam and at the Columbia River confluence where stage of the Yakima River is controlled by regulation of the Columbia River at the McNary Dam. Width of the Yakima River's wetted channel downstream of Prosser diversion dam varies, generally decreasing from over $120 \mathrm{~m}$ to about $50 \mathrm{~m}$ before increasing to over $160 \mathrm{~m}$ at the confluence of the Yakima and Columbia Rivers (fig. 4).

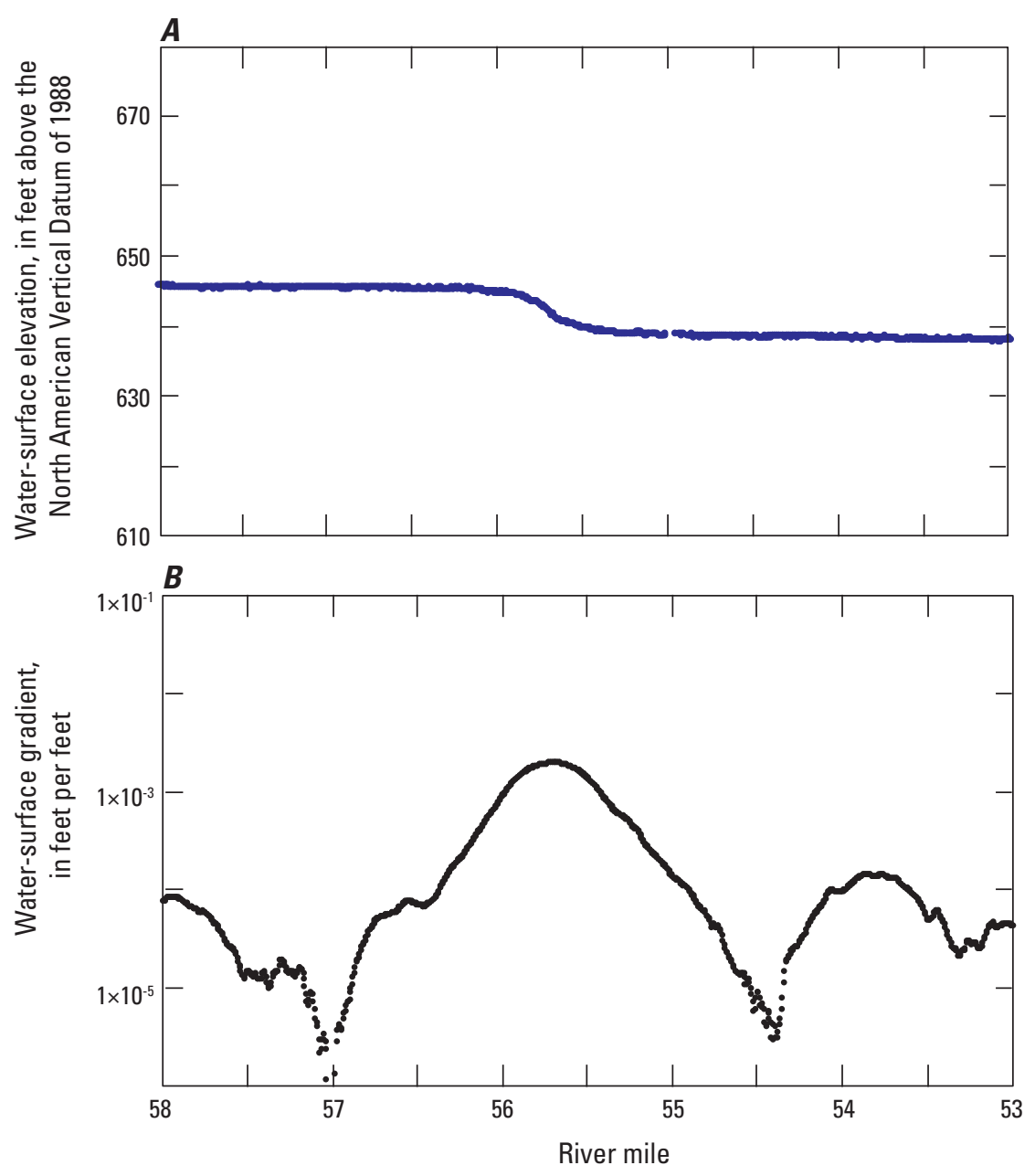

Figure 8. Longitudinal profiles of water-surface elevation and gradient derived from river miles 58-53 of the Yakima River, Washington, May-June 2015. 


\section{Thermal Profiles}

Thermal profiles of nine reaches in the lower Yakima River measured in 2018 (Gendaszek and others, 2020) were analyzed in the context of geomorphic, hydrogeologic, and hydrologic conditions and compared to thermal profiles measured in 2001, 2002, 2008, and 2009 (table 1; Vaccaro and others, 2008; Appel, 2011; Vaccaro, 2011). In order to compare thermal profiles measured during different years, each profile was referenced to river miles of the Yakima River. Due to channel changes between the establishment of river miles and the channel, particularly in the segment of the Yakima River between Sunnyside diversion dam and Mabton characterized by high channel migration rates, river miles for the thermal profiles were assigned by linear interpolation of the river mile nearest to the thermal profile. Differences in ambient river surface velocity during thermal profile surveys and the length of the profiles between established river miles resulted in variable amounts of time between river miles.

\section{Parker Reach (River Miles 103-92)}

The Parker Reach, which includes 11.1 river miles of the Yakima River between RM 103.0 and 91.9, begins downstream of the Sunnyside diversion dam where water is diverted to the Sunnyside Canal and Sunnyside fish bypass. Throughout this reach, the river flows through a wide floodplain, and its channel is characterized by a complex, anastomosing morphology with multiple channels and a mean watersurface gradient of $0.0021 \mathrm{~m} / \mathrm{m}$, which is the highest gradient of any study reach upstream of Prosser diversion dam (fig. 3). The longitudinal profile consists of a sequence of pools and riffles characterized by low and high water-surface gradients at low streamflow, respectively (fig. 9). High channel-migration rates and frequent channel avulsions within this reach have contributed to low-lying, abandoned channels throughout this reach's floodplain that are seasonally connected to surfacewater flow and conduct shallow sub-surface flow that emerges as spring brooks in several locations (fig. 5; Stanford and others, 2002). The Parker Reach was identified as a part of a priority restoration reach within the Yakima River Basin, in part because it contains the most extensive intact floodplain in the basin (Snyder and Stanford, 2001). Although the active channel is wide with extensive gravel bars and side channels, the low-flow wetted channel of the Parker Reach is among the narrowest within the lower Yakima River (fig. 4). This narrowing may reflect less streamflow because of diversion to the Sunnyside canal at the upstream end of the reach as well as losses of surface discharge to shallow alluvial aquifers. Seepage investigations between July 2003 and March 2006 identified both gains and losses of streamflow net of surfacewater inflows and diversions with a large gain of 0.86 cubic meters per second per kilometer $\left(\mathrm{m}^{3} / \mathrm{s} / \mathrm{km}\right)$ ( 49 cubic feet per second per mile $\left[\mathrm{ft}^{3} / \mathrm{s} / \mathrm{mi}\right]$ ) representing 10 percent of total streamflow between RM 98.0 and 93.1, the most downstream segment of the Parker Reach (Vaccaro, 2011).

The Parker Reach was profiled twice in 2001 by Vaccaro (2011) at channel center (fig. 10) and once in 2018 by Gendaszek and others (2020) at channel left, center, and right (figs. 11). Failure of the channel-center profile's GPS unit in 2018 resulted in an incomplete profile that was excluded from analysis in this report. During the 2018 survey, the stationary probe measured an average warming rate of 0.005 degree Celsius per minute $\left({ }^{\circ} \mathrm{C} /\right.$ minute) $(0.31$ degrees Celsius per hour $\left[{ }^{\circ} \mathrm{C} /\right.$ hour $]$ ) at the upstream end of the reach during the survey. No stationary probe was deployed during the 2001 surveys, and the warming rate at the upstream end of the reach was not measured. The stationary probe in 2018 was deployed within a cold-water anomaly associated with groundwater discharge at the upstream end of the Parker Reach, and, therefore, water temperature reported in the detrended 2018 profiles shown in figs. $11 B$ and $11 D$ may overestimate detrended watertemperature from the start of the reach. As a result, discrete cold-water anomalies were noted at RM 103.0, 95.4, and 92.7, despite showing an increase in water temperature relative to the start of the 2018 survey. No diffuse cold-water anomalies were noted, however, as the detrended water temperature measured during both the channel-right and channel-left surveys in 2018 was greater than the start of the survey.

Vaccaro (2011) attributed several cold-water anomalies in the 2001 profiles to groundwater discharge from springs and spring brooks. An additional cold-water anomaly was present at RM 94.7 in the September 13, 2001, profile but not the August 28, 2001, profiles or any of the 2018 profiles. In addition, Vaccaro (2011) attributed a discrete cold-water anomaly at RM 98.0 seen in both the August 28, 2001, and September 13, 2001, profiles (fig. 10) to discharge from Roza Canal Wasteway No. 3. The cold-water anomaly at RM 98.0, however, is not evident in either of the 2018 profiles (fig. 11). Three other surface-water inflows were present within the Parker Reach but no cold-water anomalies were present at these locations during any of the 2001 or 2018 thermal surveys. Although this feature was not documented in either of the 2018 profiles, three additional cold-water anomalies were documented in 2018 channel-right profiles (fig. 11) at alcoves near the end of point bars at RMs 103.0 and 95.4, and 92.7 where groundwater discharge does not mix readily with surface water and maintains its cold temperature. These three cold-water anomalies were not recorded by either of the 2001 surveys but the location of the anomalies at RMs 95.4 and 92.7 is consistent with broad cooling suggesting groundwater discharge to the Yakima River between RM 96.0 and RM 92.6 identified by Vaccaro (2011) within both 2001 profiles. 
Table 1. Summary of thermal profiles surveyed between 2001 and 2018, lower Yakima River, Washington.

[Date: Month/day/year]

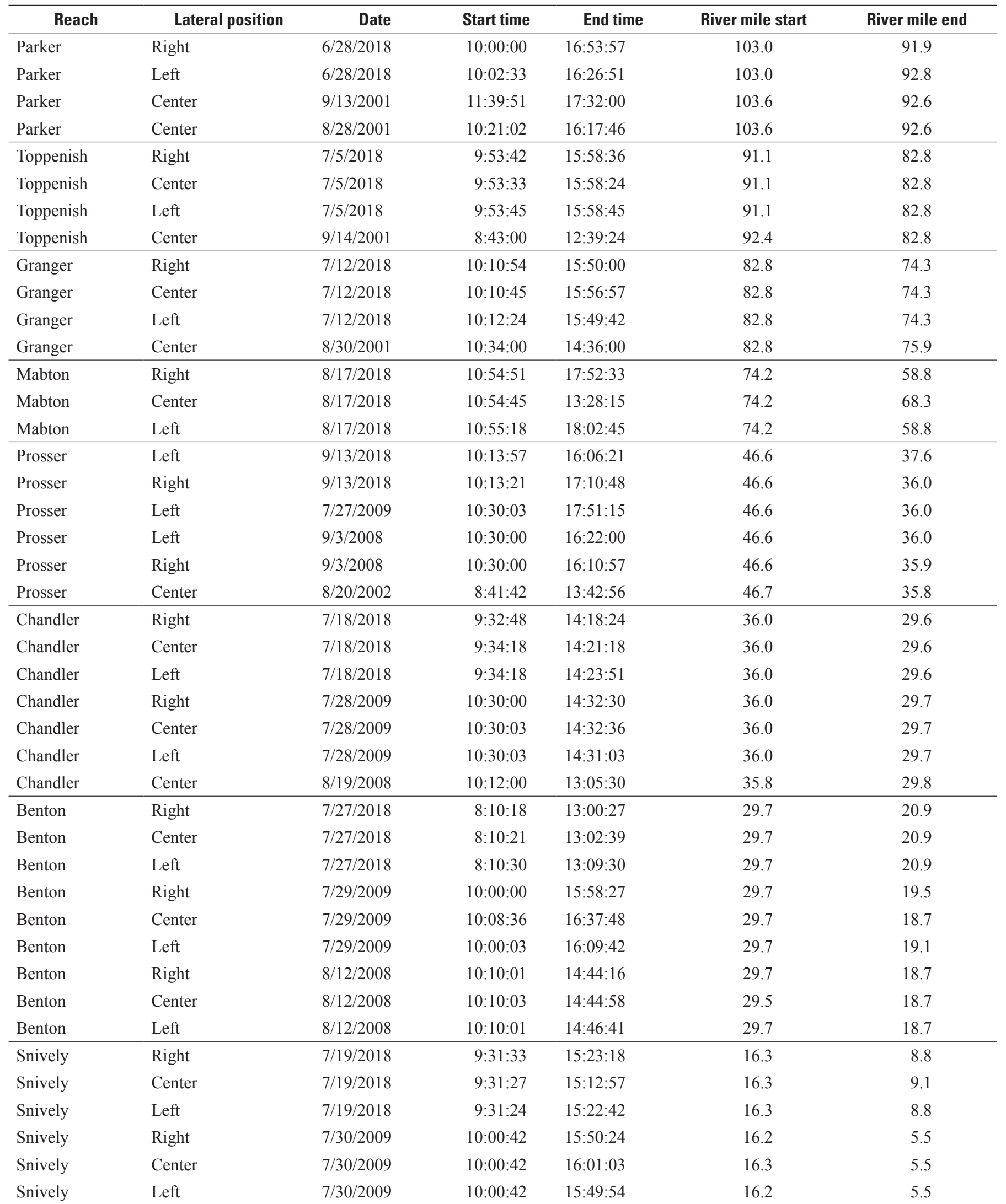


Table 1. Summary of thermal profiles surveyed between 2001 and 2018, lower Yakima River, Washington.-Continued [Date: Month/day/year]

\begin{tabular}{llrrccc}
\hline \multicolumn{1}{c}{ Reach } & Lateral position & Date & Start time & End time & River mile start & River mile end \\
\hline Snively & Right & $8 / 13 / 2008$ & $10: 37: 50$ & $15: 17: 55$ & 16.2 & 5.6 \\
Snively & Center & $8 / 13 / 2008$ & $10: 37: 55$ & $15: 17: 55$ & 16.2 & 5.5 \\
Snively & Left & $8 / 13 / 2008$ & $10: 37: 55$ & $15: 19: 40$ & 16.2 & 5.5 \\
\hline Confluence & right & $7 / 20 / 2018$ & $10: 19: 57$ & $16: 18: 24$ & 8.7 & 0.4 \\
Confluence & Center & $7 / 20 / 2018$ & $10: 16: 27$ & $16: 20: 30$ & 8.8 & 0.4 \\
Confluence & Left & $7 / 20 / 2018$ & $10: 17: 36$ & $16: 17: 12$ & 8.8 & 0.4 \\
Confluence & Right & $7 / 31 / 2009$ & $10: 00: 00$ & $13: 33: 57$ & 5.5 & 0.2 \\
Confluence & Center & $7 / 31 / 2009$ & $10: 00: 06$ & $13: 30: 54$ & 5.5 & 0.2 \\
Confluence & Left & $7 / 31 / 2009$ & $10: 37: 09$ & $13: 29: 18$ & 4.3 & 0.2 \\
Confluence & Right & $8 / 14 / 2008$ & $9: 59: 50$ & $14: 38: 40$ & 5.5 & 0.3 \\
Confluence & Center & $8 / 14 / 2008$ & $10: 00: 05$ & $14: 46: 00$ & 5.5 & 0.3 \\
Confluence & Left & $8 / 14 / 2008$ & $9: 59: 45$ & $14: 44: 35$ & 5.5 & 0.3 \\
\hline
\end{tabular}
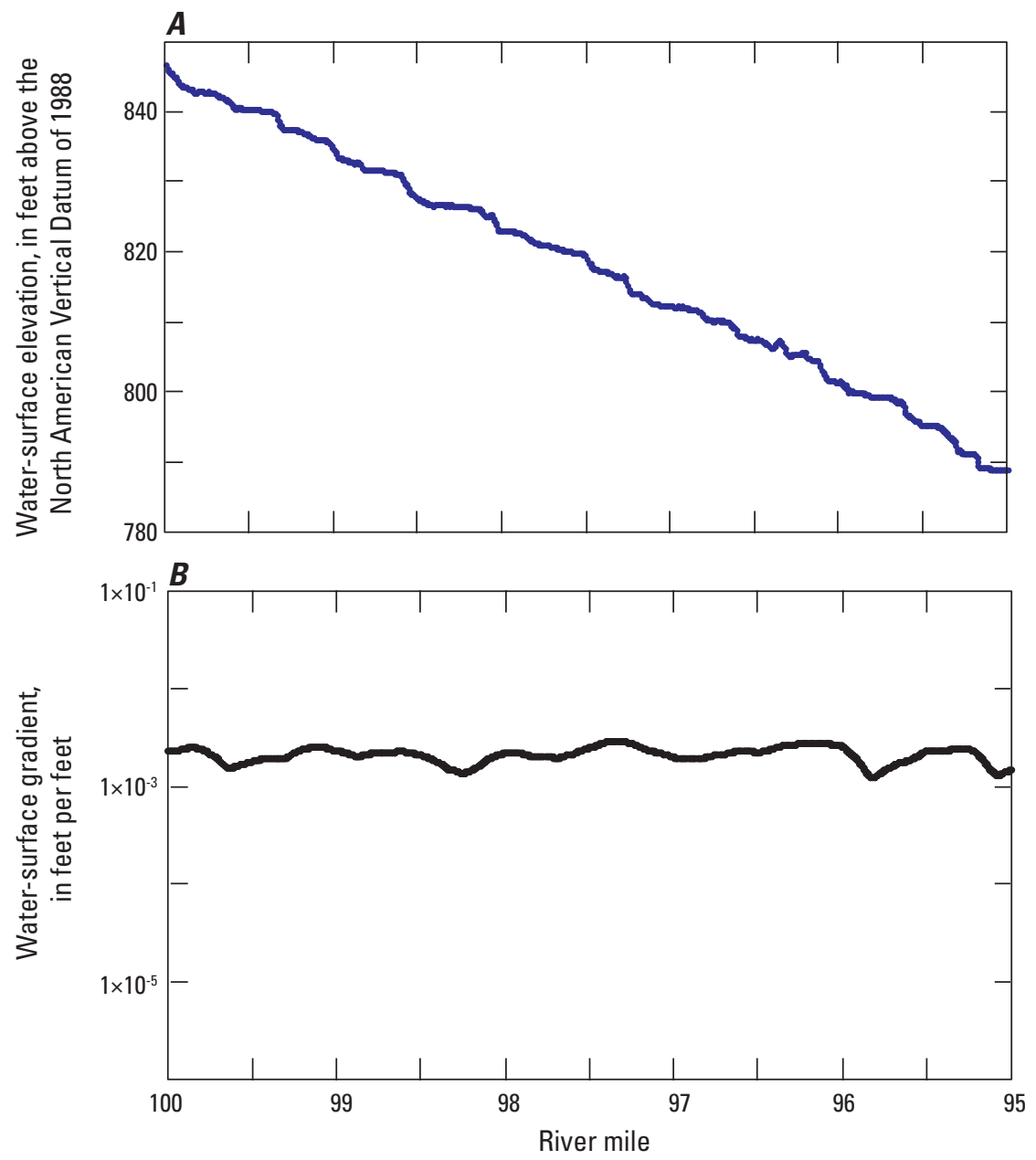

Figure 9. Longitudinal profiles of water-surface elevation and gradient between river miles 100 and 95 of the Yakima River, Washington, May-June 2015. Data derived from lidar imagery. 
A. August 28, 2001 channel center Time

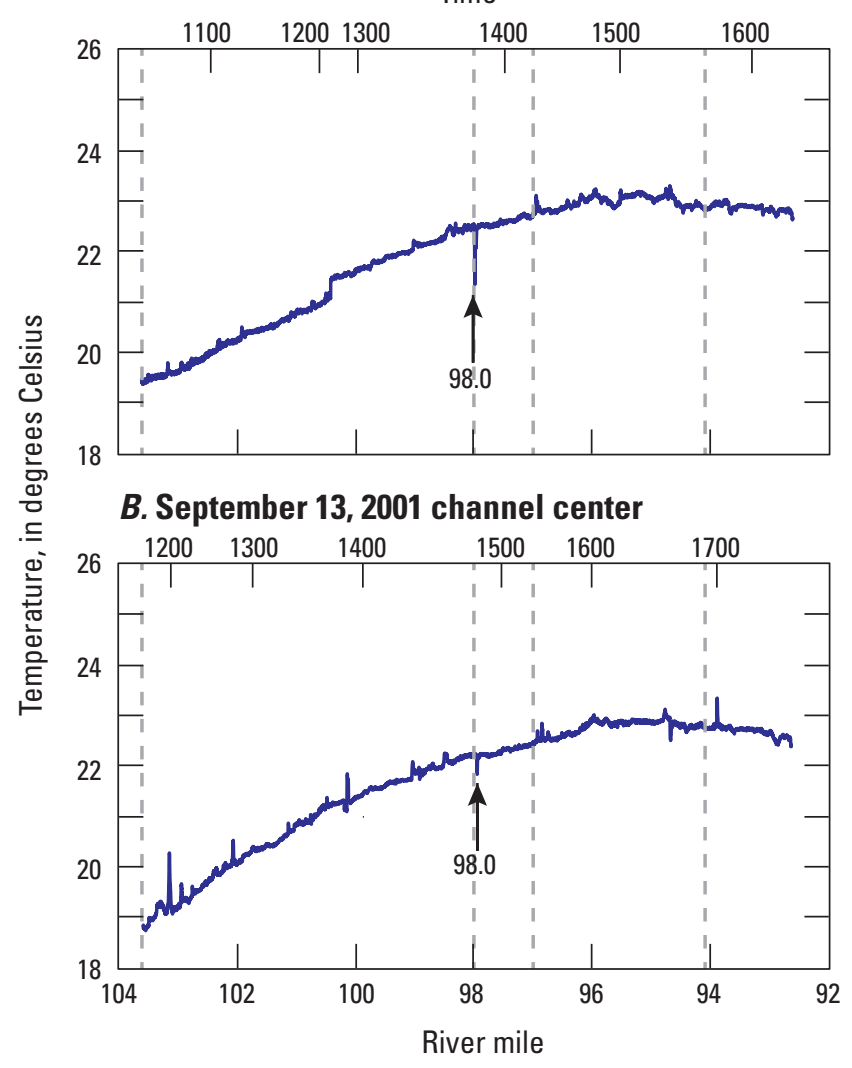

EXPLANATION

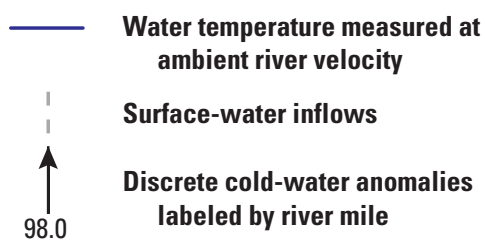

Figure 10. Thermal profiles of channel center collected August 28, $2001(A)$ and September 13, 2001 (B), Parker Reach, Yakima River, Washington.

\section{Toppenish Reach (River Miles 92-83)}

The Toppenish Reach of the Yakima River between RM 92.4 and 82.8 was characterized by a multi-threaded channel similar to the Parker Reach immediately upstream, but mean reach water-surface gradient was lower $(0.0013 \mathrm{~m} / \mathrm{m})$. Because of its wide, intact floodplain, the Toppenish Reach was also identified as part of a priority restoration reach like the Parker Reach (Snyder and Stanford, 2001). Large gravel bars, secondary channels, and abandoned channels within this reach have relatively high hydraulic conductivity compared to fine-grained overbank sediments deposited within the floodplain and may act as preferential flow paths for shallow groundwater within the reach. Eleven drains, wasteways, and canals enter the Toppenish Reach, which convey water to the Yakima River from agricultural fields, irrigation canals, and sewage treatment plants (Vaccaro, 2011).

A thermal profile of channel center measured in 2001 by Vaccaro (2011), and a set of three profiles at channel left, center, and right in 2018 (Gendaszek and others, 2020) are presented in figures 12 and 13. During the 2018 survey, a stationary probe deployed at the upstream end of the reach measured an average warming rate of $0.010^{\circ} \mathrm{C} /$ minute $(0.60$ ${ }^{\circ} \mathrm{C}$ /hour). No stationary probe was deployed during the 2001 surveys, and the warming rate at the upstream end of the reach was not measured. Seepage runs within the Toppenish Reach between 2003 and 2006 identified both seepage gains and losses net of surface-water inflows and diversions of between -0.21 and $0.44 \mathrm{~m}^{3} / \mathrm{s} / \mathrm{km}\left(-11.7\right.$ and $24.8 \mathrm{ft}^{3} / \mathrm{s} / \mathrm{mi}$; Magirl and others, 2009). Although measured streamflow gains were not consistent throughout the seepage runs, they may partly reflect the thinning of basin-fill aquifers at the eastern margin of the Toppenish structural basin that forces upward movement of groundwater in surficial aquifers and its discharge into the Yakima River (Vaccaro, 2011). Additionally, groundwater flow paths within surficial aquifers are relatively steep and perpendicular to the Yakima River on its left bank (Vaccaro and others, 2009), suggesting that most groundwater discharge to the Toppenish Reach originates from the uplands to the north.

Vaccaro (2011) attributed temperature variability in the 2001 thermal profile to groundwater discharge from seeps, springs, and surface-water features, including wasteways and drains. Temperature stabilizes within the 2001 thermal profile between RM 84 to 83 where the alluvial floodplain also narrows and the channel abuts a terrace suggesting diffuse groundwater input to the river within this segment; however, water temperature was not measured at a stationary location in 2001 and the temperature change of this stabilization relative to diurnal increases in temperature could not be evaluated. A discrete cold-water anomaly was also measured in this segment at RM 83.1 during the 2001 survey, which Vaccaro (2011) attributed to spring discharge. Several drains including Drainage Irrigation District 27, Sub-drain No. 35, and Granger Drain as well as outflow from the Granger Sewage Treatment Plant discharge into the Yakima River within one-half river mile of this anomaly contributing to elevated groundwater tables near this location. 


\section{A. June 28, 2018 channel left}

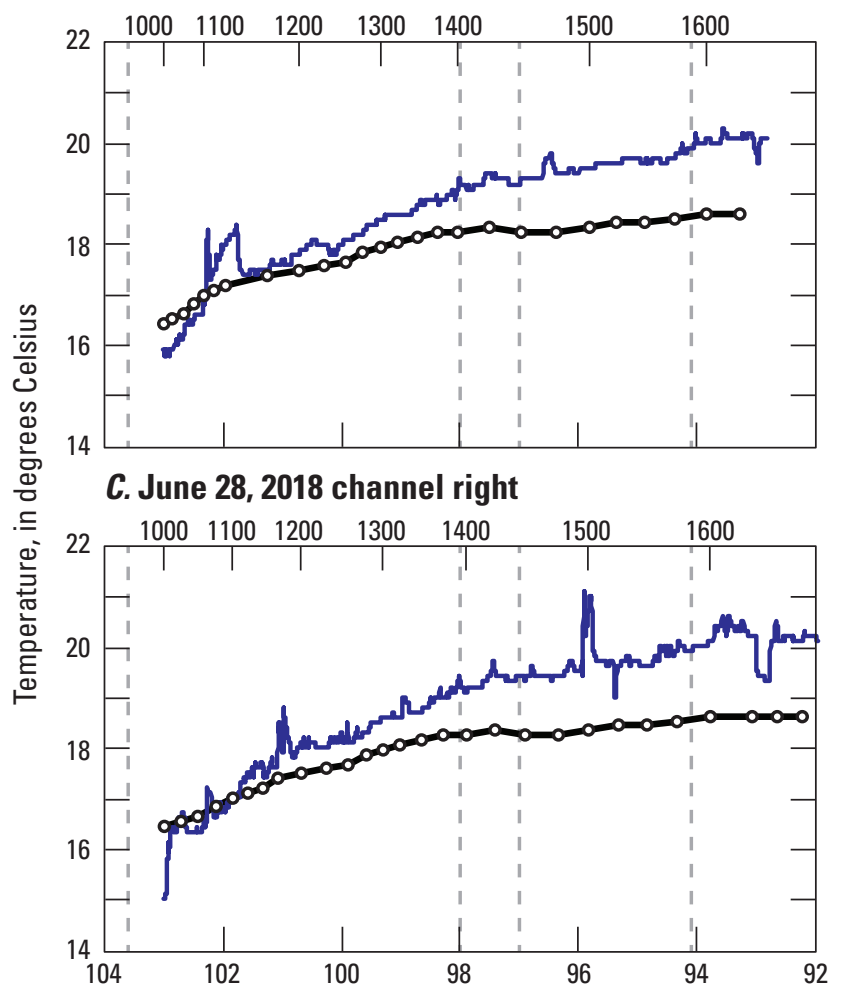

B. June 28, 2018 channel left

Time

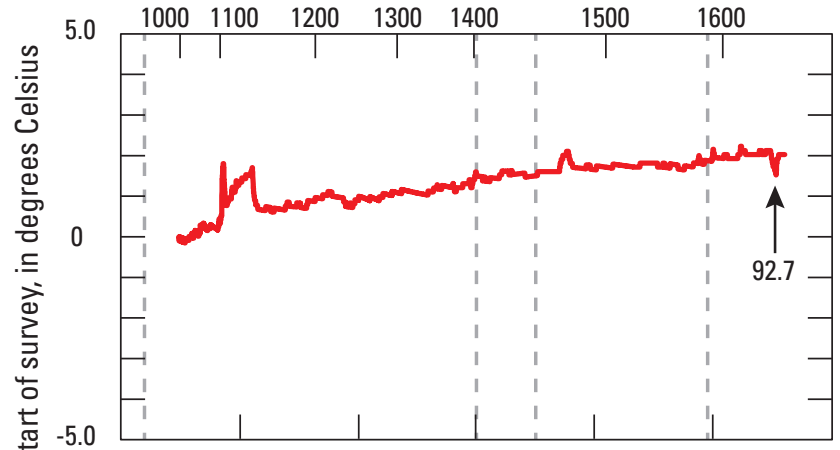

D. June 28, 2018 channel right

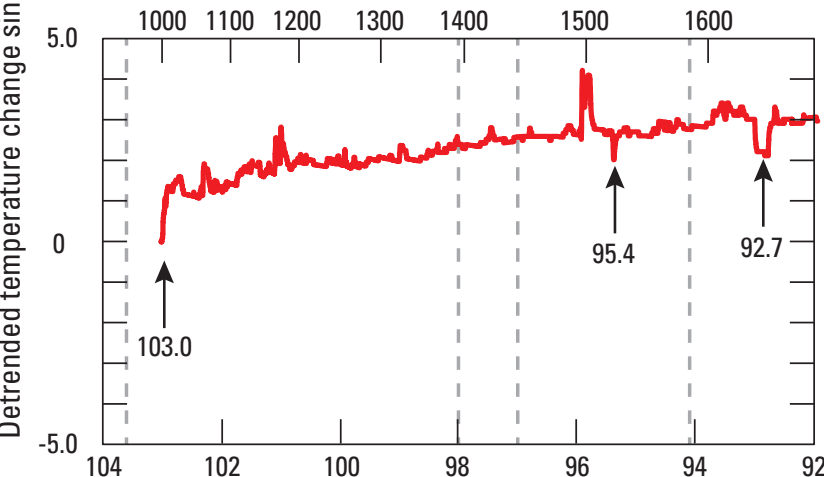

River mile

\section{EXPLANATION}

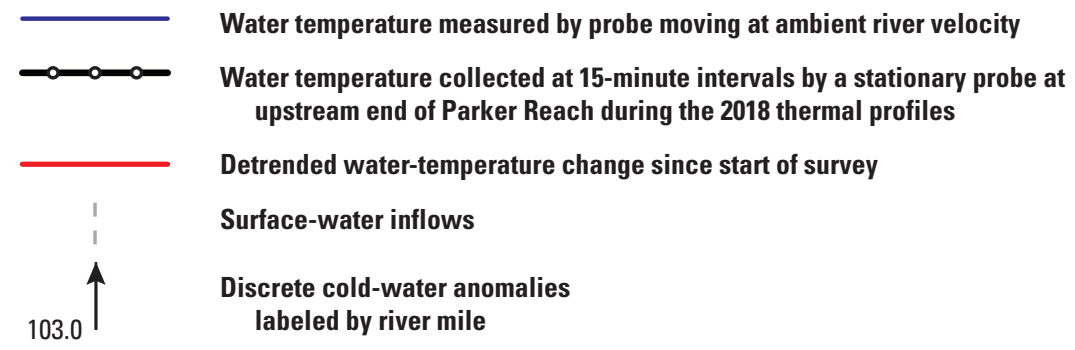

Figure 11. Thermal profiles and detrended temperature change, since the start of survey, of channel left and channel right, Parker Reach, Yakima River, June 28, 2018. 


\section{September 14, 2001 channel center}

Time

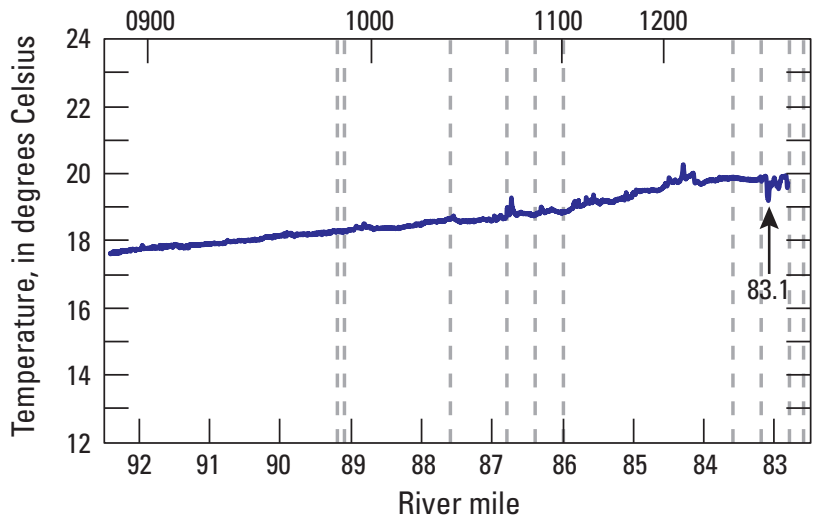

EXPLANATION

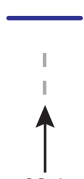

\section{Surface-water inflows \\ Discrete cold-water anomalies labeled by river mile}

Water temperature collected at ambient river velocity

Figure 12. Thermal profile of channel center, Toppenish Reach, Washington, September 14, 2001.

Large-scale channel migration occurred between 2001 and 2018 in the Parker Reach, and cold-water anomalies were detected at different locations in the 2001 and 2018 profiles. Differences in thermal profiles between 2001 and 2018 may have also resulted from differential diurnal heating during the 2018 surveys, which were conducted in July, and the 2001 survey, which was conducted in September. For example, a large cold-water anomaly within an alcove at the downstream end of a point bar was measured at RM 91 at the start of the 2018 survey, which is not present in the 2001 profile. In 2001, the main channel of the Yakima River was present upstream of the alcove where the 2018 cold-water anomaly was measured, but a point bar was subsequently deposited as the river channel migrated to its 2018 location. The former path of the Yakima River's channel may provide a subsurface path for groundwater flow to discharge into the alcove before mixing with water conveyed from upstream. Additional discrete coldwater anomalies present in 2018 but not in 2001 occurred at
RM 90.6 in the channel-right profile, RM 89.3 in the channelcenter profile, RM 85.3 in the channel-left profile, RM 84.5 in the channel-center profile, and 83.9 in the channel-left profile. Each of these discrete cold-water anomalies occurred near the outlet of a secondary channel or an alcove at the end of a point bar, which suggests that the 2001 survey, which only measured channel-center temperature, may have missed these cold-water anomalies.

\section{Granger Reach (River Miles 83-74)}

The Granger Reach is an 8.5-mile section of the lower Yakima River from the City of Granger at RM 82.8 to 74.3. The Yakima River within this reach flows across a wide floodplain that is bounded to the north by terraces composed of Touchet Beds and bedrock of the Saddle Mountains Basalt. Mean water-surface gradient of the Granger Reach was 0.0008 $\mathrm{m} / \mathrm{m}$, reflecting decreasing water-surface gradient relative to the upstream Parker and Toppenish Reaches. A thermal profile of channel center of the Granger Reach was measured in 2001 from RM 82.8 to 75.9 (Vaccaro, 2011; fig. 14), and three profiles of channel left, center, and right were measured in 2018 from 82.8 to 74.3 (Gendaszek and others, 2020; fig. 15). During the 2018 survey, the stationary probe measured an average warming rate of $0.010^{\circ} \mathrm{C} /$ minute $\left(0.59^{\circ} \mathrm{C}\right.$ /hour $)$ at the upstream end of the reach; no stationary probe was deployed during the 2001 surveys. Similar to the Toppenish Reach immediately upstream, channel migration and avulsion between 2001 and 2018 contributed to differences in the location of the channel at several locations throughout the Granger Reach, including the cutoff of a meander bend between RM 77 and RM 76 at the downstream end of the reach. Three major surface-water inflows enter the Yakima River in the Granger Reach, which include Marion Drain (RM 82.6), Toppenish Creek (RM 80.0), and Coulee Drain (RM 77.0). A series of five seepage runs between 1988 and 2006 identified both streamflow gains and losses to Granger Reach net of surfacewater inflows and diversions. Seepage losses between -0.10 and $-0.35 \mathrm{~m}^{3} / \mathrm{s} / \mathrm{km}\left(-5.5\right.$ and $\left.-19.7 \mathrm{ft}^{3} / \mathrm{s} / \mathrm{mi}\right)$ were identified during seepage runs in 2003, 2005, and 2006 and seepage gains of 0.19 and $0.18 \mathrm{~m}^{3} / \mathrm{s} / \mathrm{km}(11.0$ and $10.4 \mathrm{ft} 3 / \mathrm{s} / \mathrm{mi})$ identified during 1988 and 2004, respectively (Magirl and others, 2009). Variability in seepage gains and losses within the Granger Reach may represent interannual and seasonal variability within hydrologic conditions. 


\section{A. July 5, 2018 channel left}

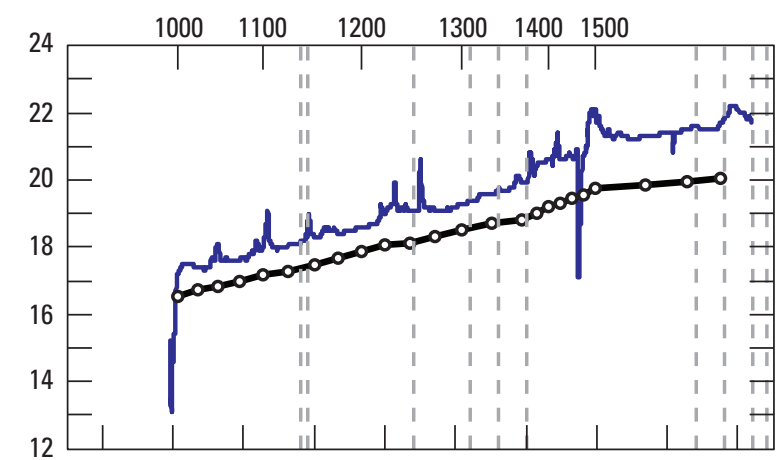

C. July 5, 2018 channel center

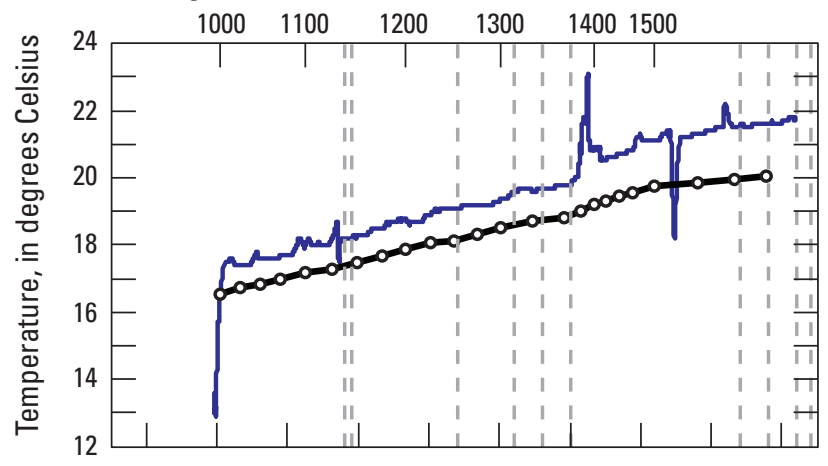

E. July 5, 2018 channel right

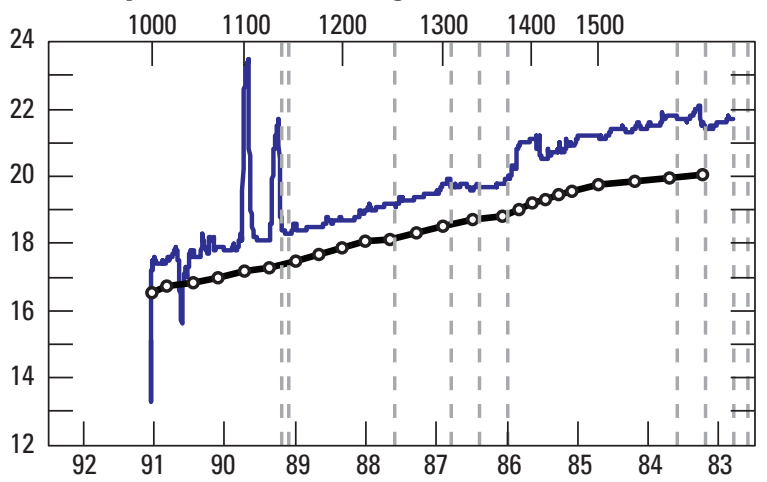

B. July 5, 2018 channel left

Time

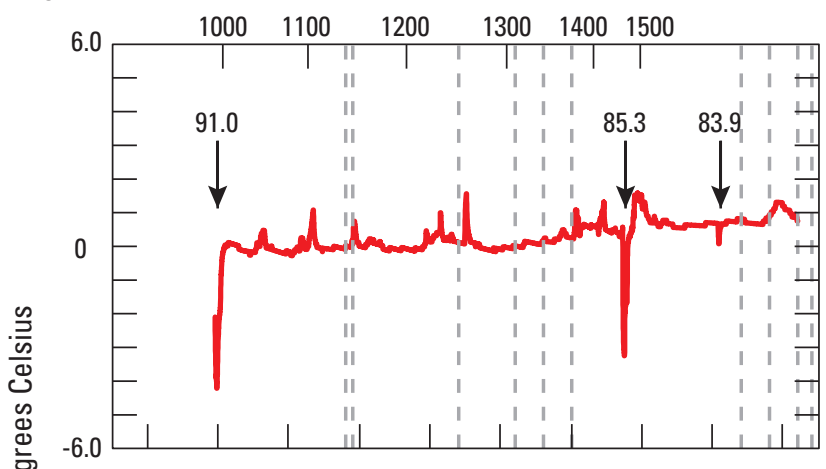

\section{July 5, 2018 channel center}

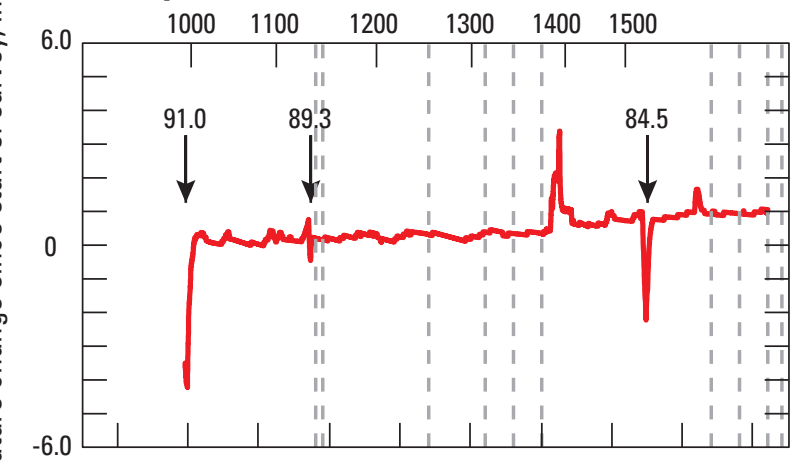

F. July 5, 2018 channel right

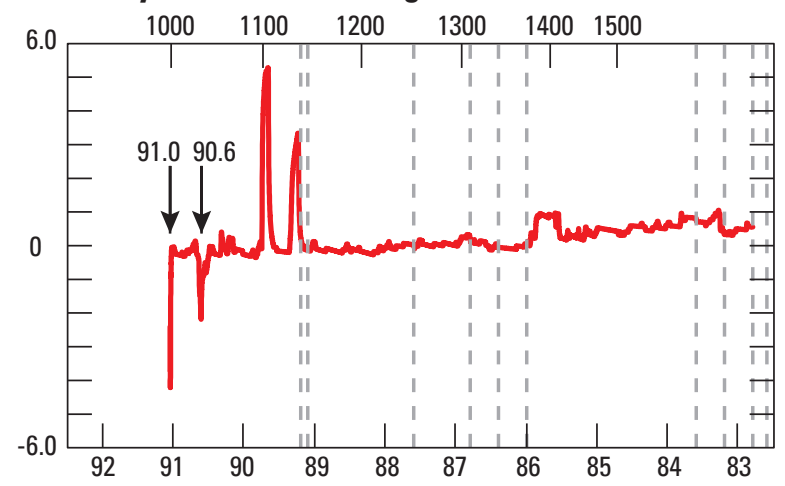

River mile

\section{EXPLANATION}

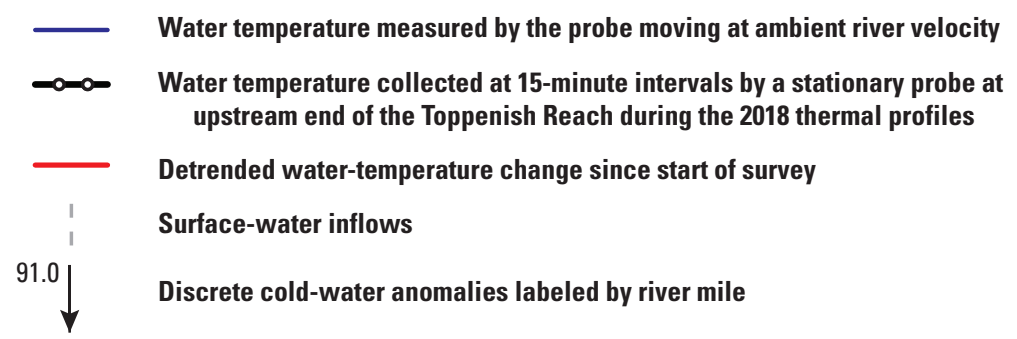

Figure 13. Thermal profiles and detrended temperature change, since the start of survey, of channel left $(A, B)$ and channel right $(C, D)$, Toppenish Reach, Yakima River, Washington, June 5, 2018. 


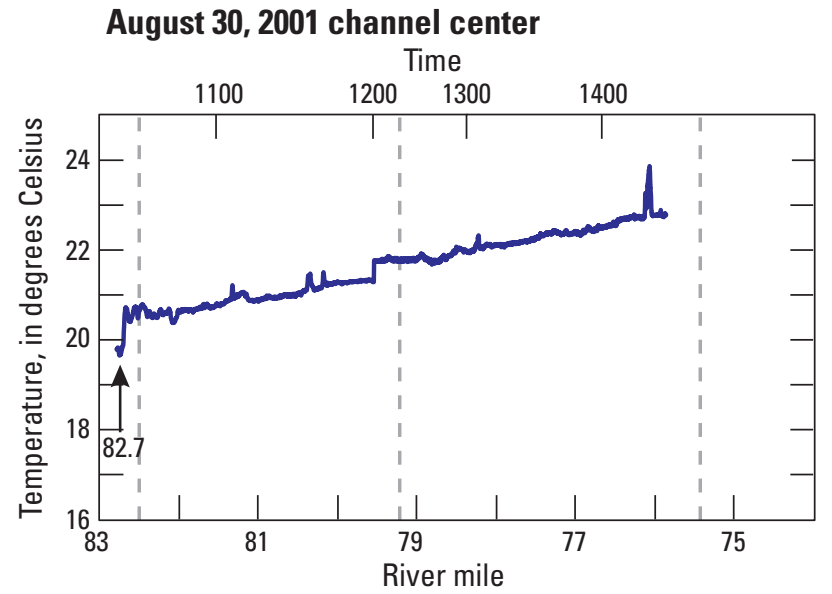

EXPLANATION

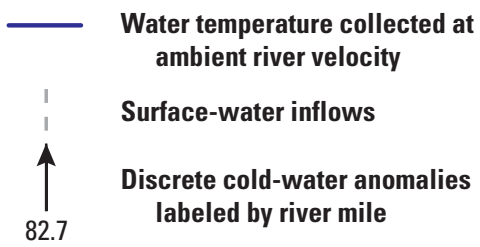

Figure 14. Thermal profile of the channel center of Granger Reach, Yakima River, Washington, August 30, 2001.

Relative to other reaches in the Yakima River downstream of Sunnyside diversion dam, discrete cold-water anomalies are largely absent in the 2001 thermal profile except for the most upstream part of the profile near RM 82.7 (Vaccaro, 2011). The cold-water anomaly measured at the upstream part of the 2001 survey was not measured during any of the 2018 surveys, suggesting that this cold-water anomaly was not persistent through time. Although discrete cold-water anomalies are not present in the rest of the 2001 profile, two zones of thermal profile stabilization including RM 82.7 - RM 81.5 and RM 79.5 - RM 78.2 were noted by Vaccaro (2011) and attributed to broad groundwater discharge. The magnitude of temperature stabilization within these locations relative to temperature at a stationary location at the upstream end of the reach was not known because no stationary temperature probe was deployed by Vaccaro (2011). These zones of temperature stabilization were not recorded during the 2018 surveys; however, large-scale geomorphic changes between 2001 and 2018 in this area shifted the channel into an alcove that receives groundwater discharge and is the source of a large cold-water anomaly at RM 79.8 within the channel-left profile measured in 2018. Additional zones of cold water were measured by the channel-left and channel-center profiles at RM 76.7 at the location of a recently scoured pool, within a zone of temperature stabilization between RM 76.7 and 77.3, and by the channel-right profile at RM 81.0.

\section{Mabton Reach (River Miles 74-59)}

Three thermal profiles were measured on channel left, right, and center of the Mabton Reach between RM 74.2 and 58.8 in 2018 (fig. 16). Mean water-surface gradient of this reach $(0.0001 \mathrm{~m} / \mathrm{m})$ was the lowest water-surface gradient of all nine surveyed reaches and groundwater gradients within surficial aquifers were correspondingly low (Vaccaro and others, 2009). As a result, the hydraulic gradients between groundwater and surface water were likely less within the Mabton Reach compared to other study reaches. Three seepage runs between 1988 and 2006 identified both streamflow gains and losses to Mabton Reach net of surface-water inflows and diversions with seepage losses between -0.04 and 0.16 $\mathrm{m}^{3} / \mathrm{s} / \mathrm{km}$ (-2.2 and $8.9 \mathrm{ft}^{3} / \mathrm{s} / \mathrm{mi}$; Magirl, 2009). The planform channel was highly sinuous as the Yakima River meandered across a wide, low-gradient floodplain and did not contact any terraces at the margins of the floodplain like the Parker, Toppenish, and Granger Reaches upstream. Because stationary probes deployed at the upstream and downstream ends of the survey were stolen and not recovered, water temperature measured at USGS Gage at Prosser (12509489) was used and is plotted in fig. 16. Water temperature at the Prosser Gage was several degrees higher than temperatures recorded during the longitudinal survey, and increased at an average warming rate of $0.002{ }^{\circ} \mathrm{C} /$ minute $\left(0.14^{\circ} \mathrm{C} /\right.$ hour $)$ during the survey.

Deviations from the diurnal warming were largely absent from the channel left, right, and center profiles except for a cold-water anomaly measured in the channel-left and channelcenter profiles at RM 61.0, the outlet of the Sulphur Creek Wasteway, which conveys irrigation returns to the Yakima River. Cooling is greatest at the outlet of the Sulphur Creek Wasteway; water temperature stabilizes for the rest of the survey to RM 58.5 within all three profiles. This stabilization may reflect groundwater discharge to the reach or may reflect a decrease in the rate of diurnal warming as recorded by the stationary temperature probe located at the USGS Gage at Prosser. Eight other drains plus Satus Creek contributed water during the surveys to the Mabton Reach, but associated cold-water anomalies were not measured during the thermal surveys. At some inflows, water temperature was higher than the main channel of the Yakima River (for example, Satus Drain no. 3 at RM 62.4) and at other inflows no difference in water temperature between the inflow and main channel of the Yakima River was discernable (for example, Satus Creek at RM 69.6). 


\section{A. July 12, 2018 channel left}

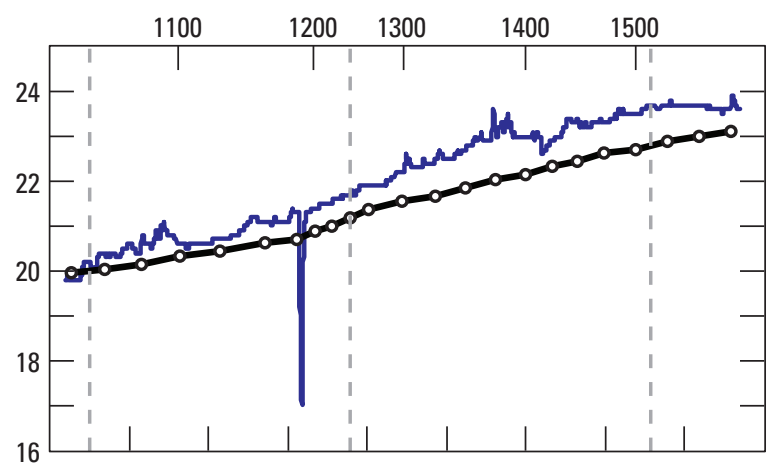

\section{July 12, 2018 channel center}

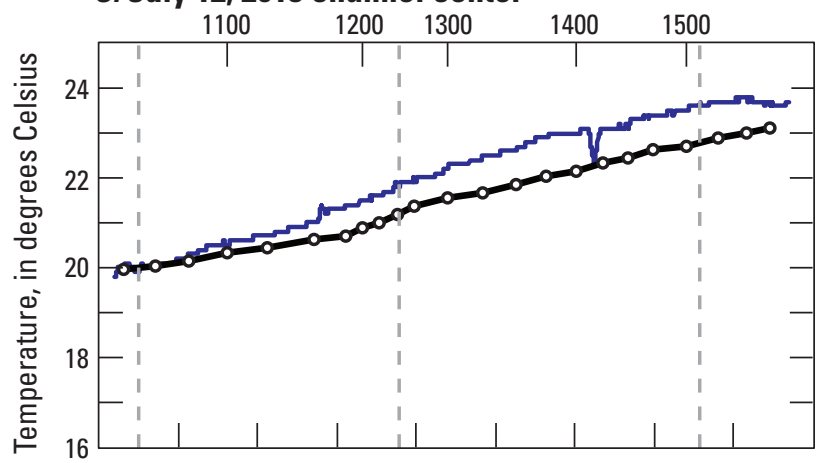

\section{E. July 12, 2018 channel right}

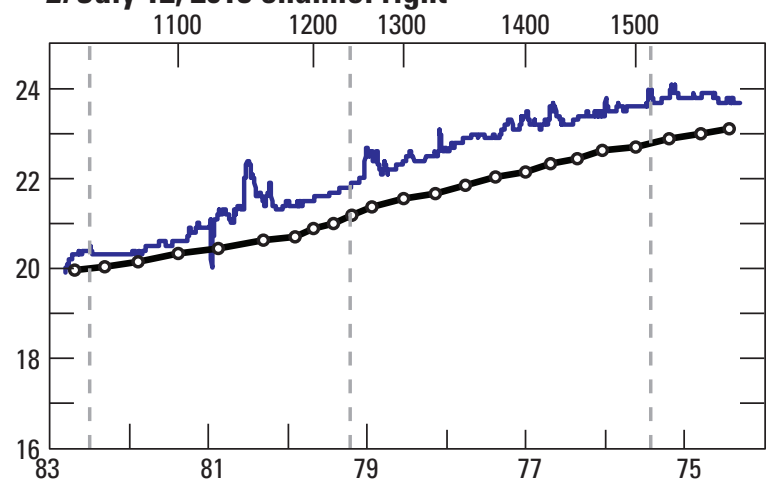

\section{B. July 12, 2018 channel left}

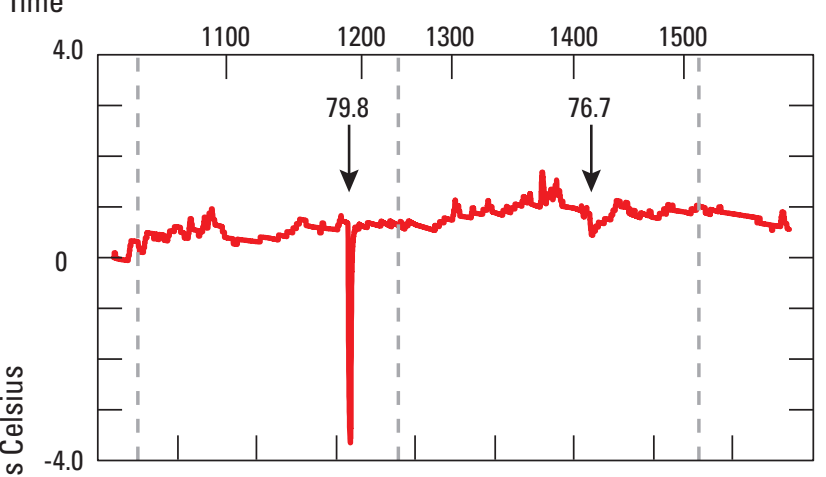

\section{July 12, 2018 channel center}

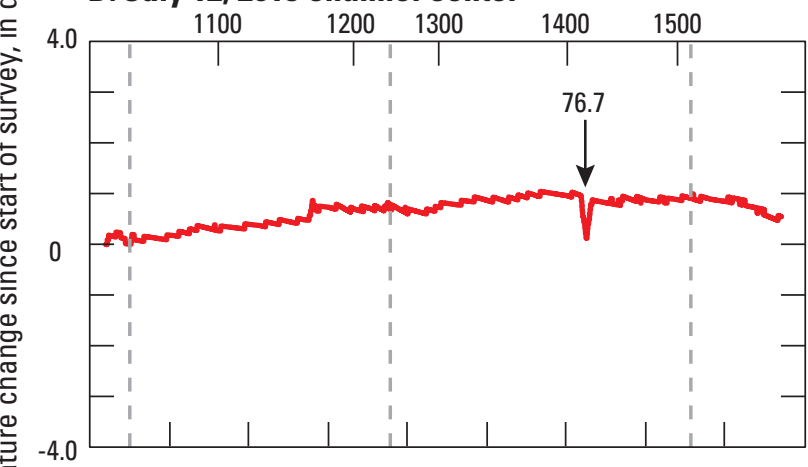

F. July 12, 2018 channel right

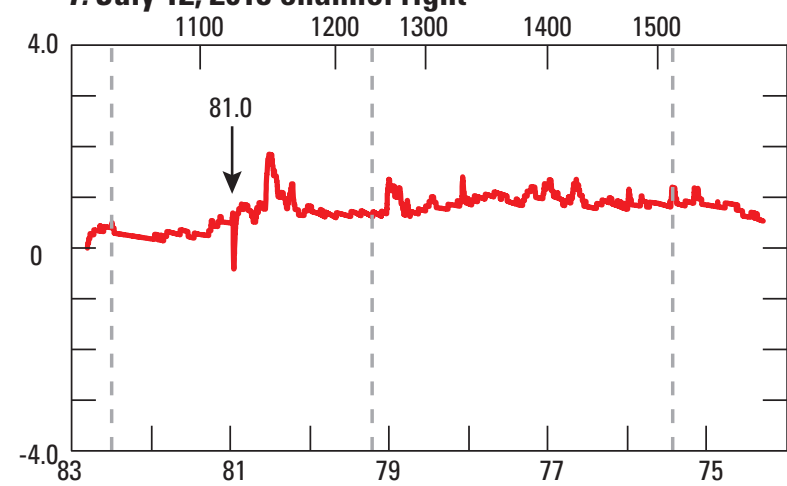

River mile

\section{EXPLANATION}

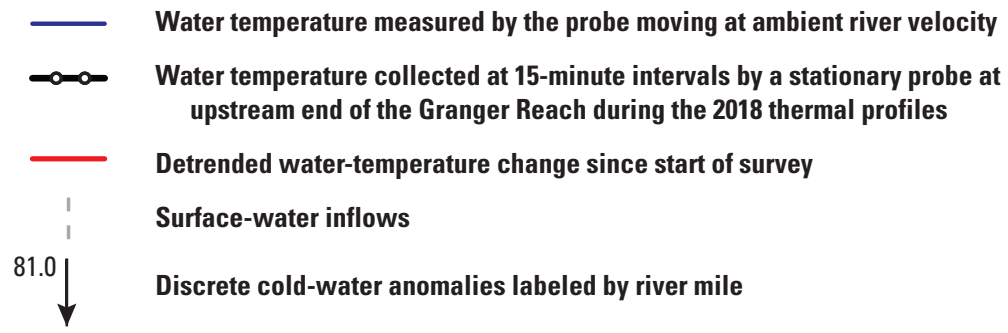

Figure 15. Thermal profiles and detrended temperature change, since the start of survey, of channel left $(A$ and $B)$, channel center $(C$ and $D)$, and channel right $(E$ and $F$, Granger Reach, Yakima River, Washington, July 12, 2018. 


\section{A. August 17, 2018 channel left}

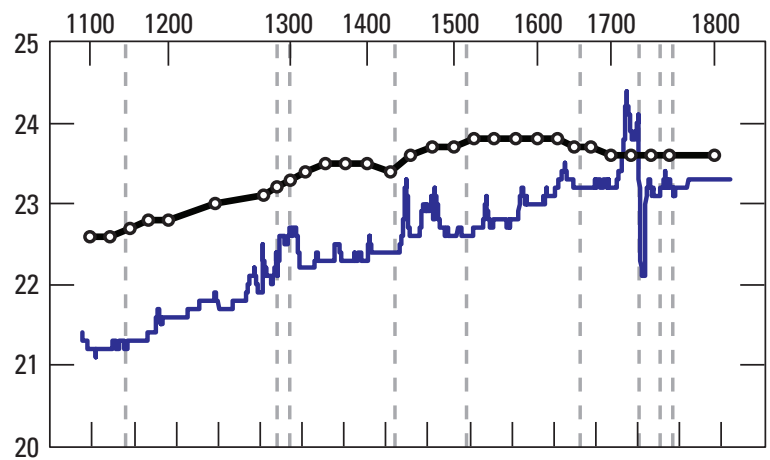

C. August 17, 2018 channel center

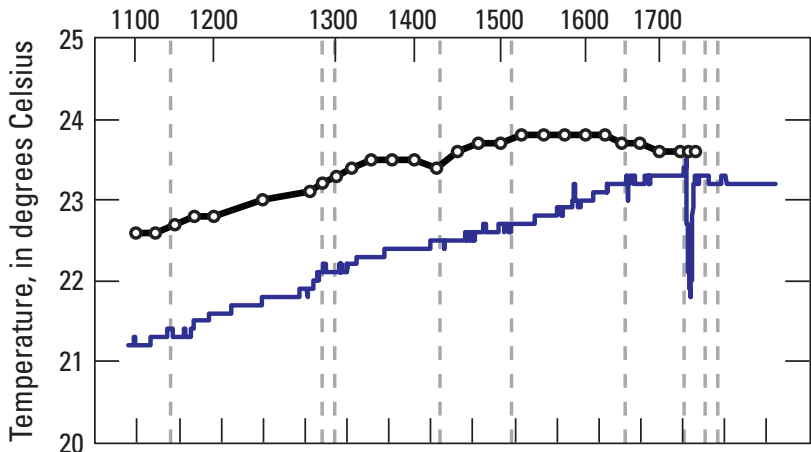

E. August 17, 2018 channel right

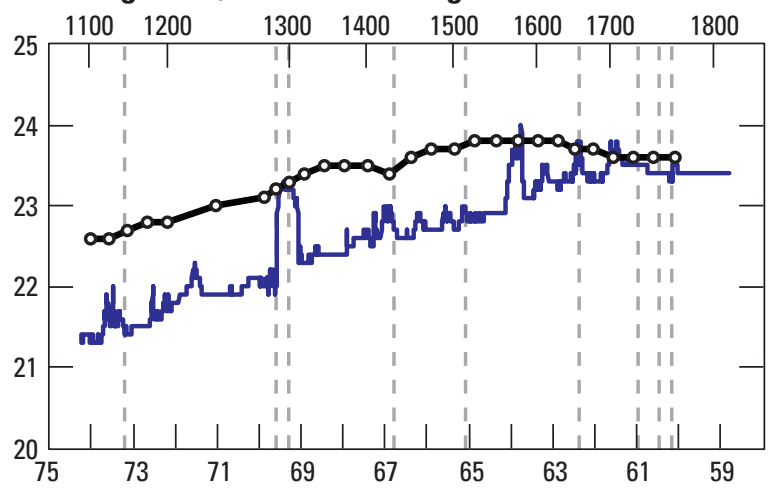

\section{B. August 17, 2018 channel left}

Time

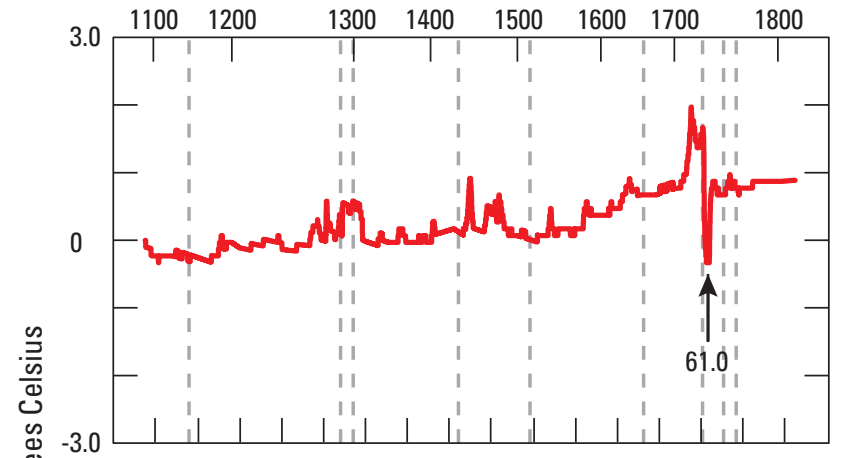

st 17, 2018 channel cente

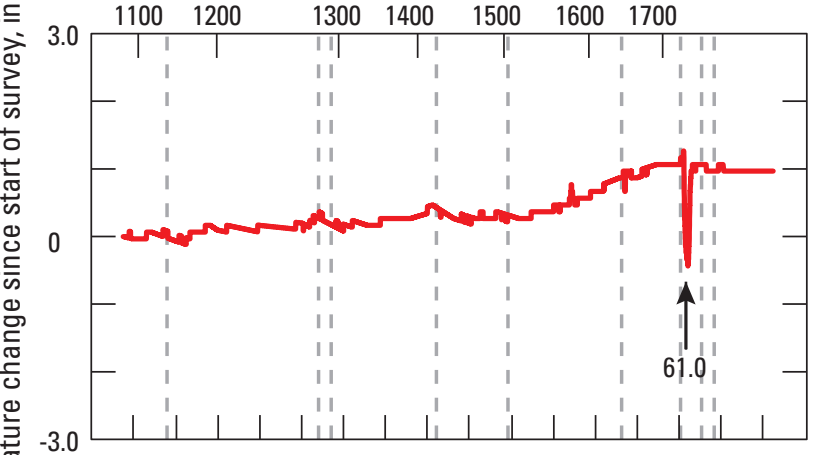

F. August 17, 2018 channel right

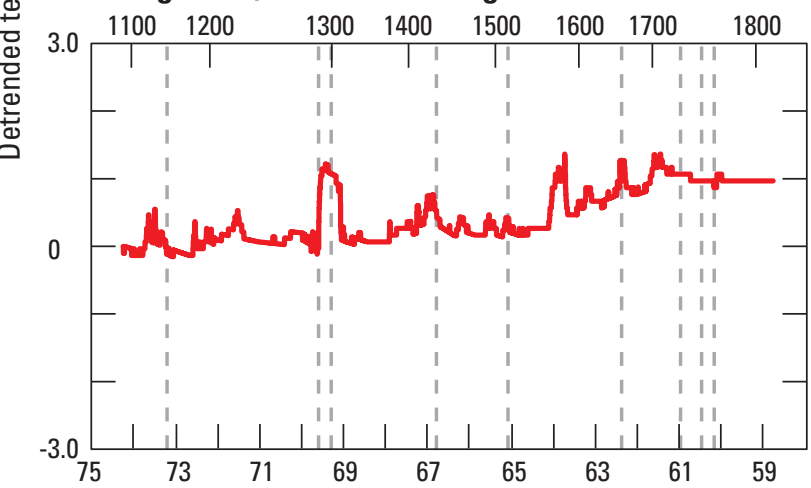

River mile

\section{EXPLANATION}

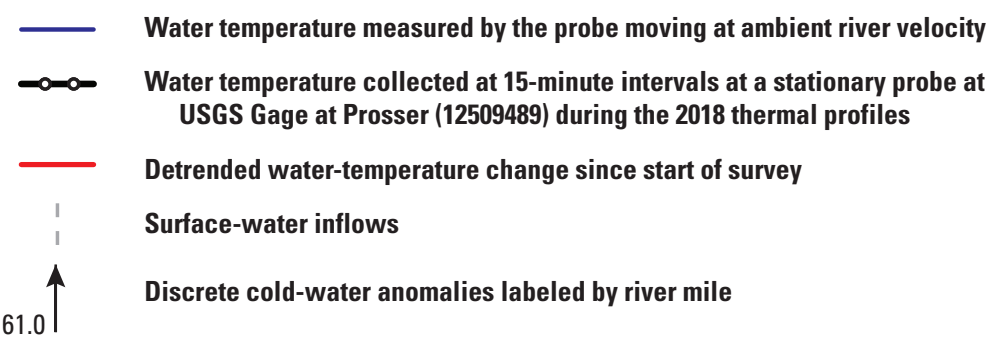

Figure 16. Thermal profiles and detrended temperature change, since the start of survey, of channel left $(A$ and $B)$, channel center ( $C$ and $D)$, and channel right ( $E$ and $F$, Mabton Reach, Yakima River, Washington, August 17, 2018. 


\section{Prosser Reach (River Miles 47-36)}

The Prosser Reach between Prosser (RM 46.6) and the Chandler Power Plant (RM 35.8) begins immediately downstream of the Prosser diversion dam where the Yakima River increases in gradient to $0.002 \mathrm{~m} / \mathrm{m}$, the highest gradient of the nine study reaches (fig. 3). The water-surface gradient of this reach is controlled by near-surface bedrock of the Saddle Mountains Basalt at the margin of the Benton basin, and relative to upstream reaches, the alluvial aquifer of the Prosser Reach is correspondingly thin and limited in extent (Jones and others, 2006). The Prosser diversion dam diverts water to the Chandler Canal, which follows the left bank of the Prosser Reach until it returns to the Yakima River at the Chandler Powerhouse at the downstream end of the reach.

Thermal profiles of the Prosser Reach were first measured in 2002 and were repeated in 2008, 2009, and 2018 (figs. $17,18,19,20)$. During the 2018 survey, the stationary probe measured an average warming rate of $0.0019^{\circ} \mathrm{C} /$ minute $(0.11$ ${ }^{\circ} \mathrm{C} /$ hour) at the upstream end of the reach. The average rate of warming measured by the stationary probe deployed at the upstream end of the reach during the 2009 survey was 0.0021 ${ }^{\circ} \mathrm{C} /$ minute $\left(0.13{ }^{\circ} \mathrm{C} /\right.$ hour $)$. No stationary probes were deployed during the 2002 or 2008 surveys, and the rate of warming was not calculated. Two profiles of channel left and channel right from 2018 largely track diurnal increases in stream temperature measured at the stationary water-temperature probe at the upstream end of the reach at USGS Gage at Prosser (12509489); however, the detrended water temperature between RM 43 and 42 is less than the start of the channel-left

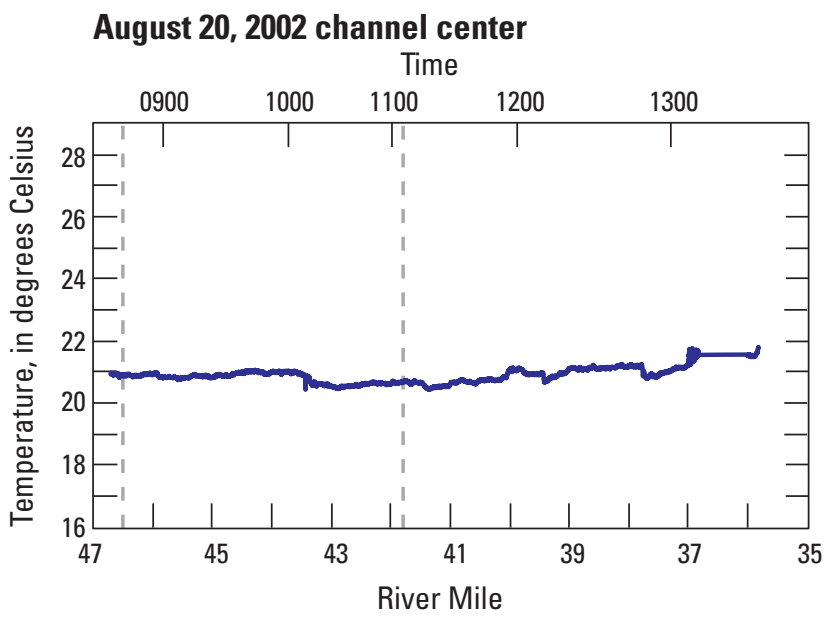

EXPLANATION

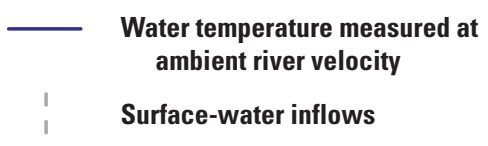

Figure 17. Thermal profile of Prosser Reach, Yakima River, Washington, August 30, 2002. and channel-right profiles (figs. 20B, 20D), suggesting coldwater discharge to this part of the Prosser Reach. Additionally, the temperature increase in the Prosser Reach was small, indicating diffuse groundwater inflow, which is consistent with large groundwater gains measured during 1999 and 2004 seepage runs of 0.23 and $0.56 \mathrm{~m}^{3} / \mathrm{s} / \mathrm{km}(13.3$ and $32.2 \mathrm{ft} 3 / \mathrm{s} / \mathrm{mi})$, respectively (Magirl and others, 2009). The small increase in temperature may also reflect the steep water-surface gradient of the Prosser Reach and correspondingly short residence time of water within the reach. Several departures from the diurnal warming were measured during both the channel-left and channel-right surveys in 2018; however, no cold-water anomalies were noted at the effluent of the Prosser Wastewater Treatment Plant or Prosser Fish Hatchery immediately downstream of the Prosser diversion dam. The first large decrease in water temperature was measured at RM 44.7 during the 2018 channel-right survey within a large riffle, but this cold-water

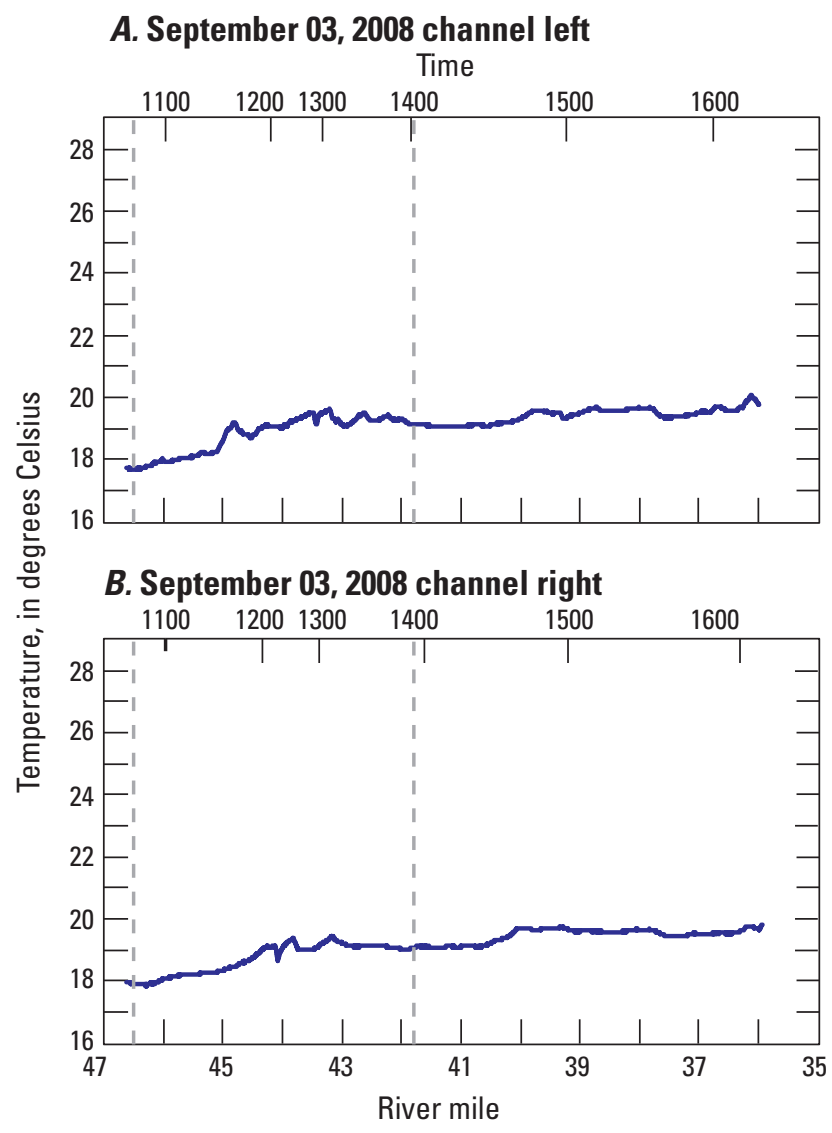

EXPLANATION

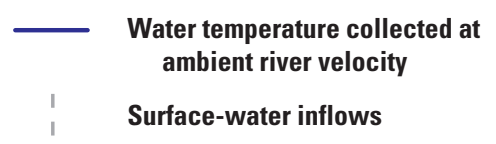

Figure 18. Thermal profile of channel left $(A)$ and channel right (B), Prosser Reach, Yakima River, Washington, September 3, 2008. 


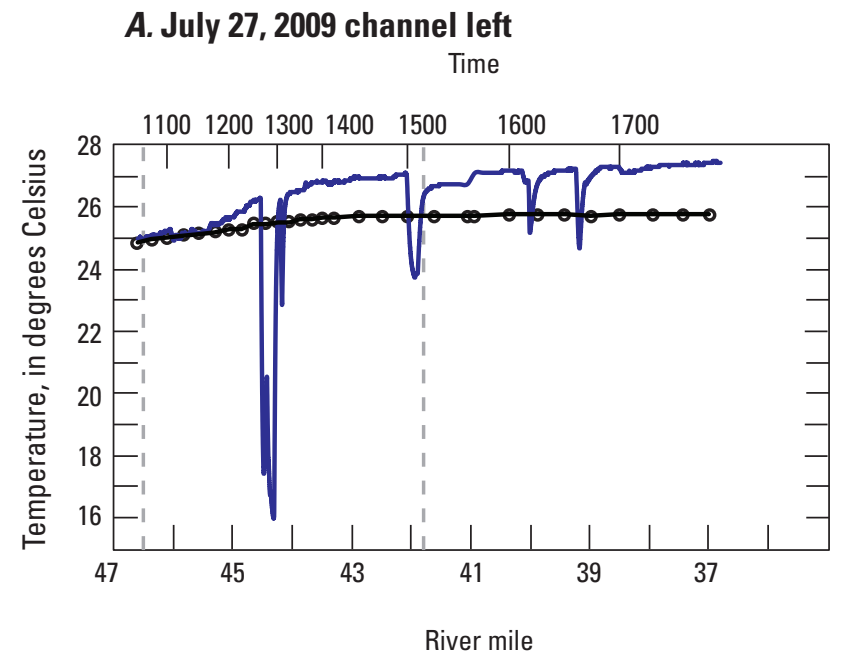

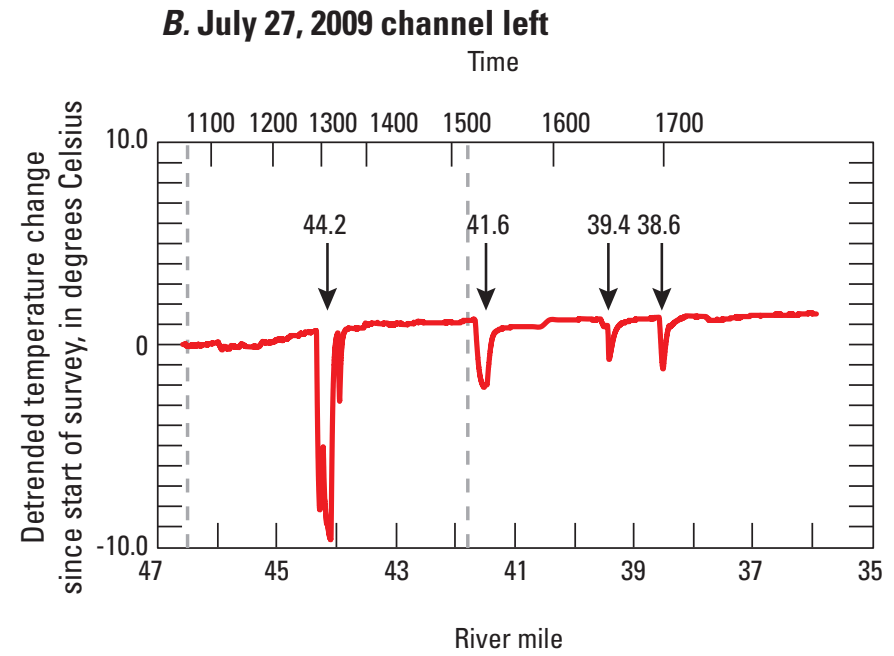

EXPLANATION

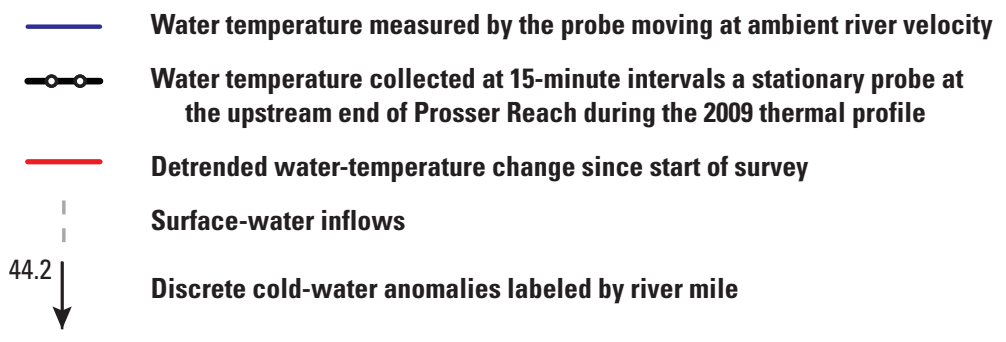

Figure 19. Thermal profiles and detrended temperature change of channel left $(A$ and $B)$, Prosser Reach, Yakima River, Washington, July 27, 2009.

anomaly was not measured during the 2002, 2008, or 2009 surveys. Several additional cold-water anomalies associated with bank seeps were measured during the 2018 channel-left survey at RMs 43.7, 43.1, 41.0, and 38.6. An additional coldwater anomaly occurred at the outlet of Snipes and Spring Creeks at RM 41.6. Several of these cold-water anomalies were measured during the 2009 thermal survey, but they were largely absent from the 2008 and 2002 profiles.

\section{Chandler Reach (River Miles 36-30)}

The Chandler Reach between RM 36.0 at the Chandler Power Plant and RM 29.7 at Benton City is largely bedrock controlled with a mean water-surface gradient of $0.0012 \mathrm{~m} / \mathrm{m}$. Like the Prosser Reach immediately upstream, the Chandler Reach is bounded to the south by bedrock of the Saddle Mountains Basalt and the overlying alluvial aquifer is thin and limited in extent. A thermal profile of channel center of the Chandler Reach was measured in 2008 (fig. 21), and thermal profiles of channel center, left, and right were measured in 2009 and 2018 (figs. 22, 23). During both the 2009 and 2018 surveys, stationary probes at the upstream end of the reach measured an average warming rate of $0.009^{\circ} \mathrm{C} /$ minute $(0.54$
${ }^{\circ} \mathrm{C} /$ hour). No stationary probes were deployed during the 2008 survey and the corresponding rate of warming was not calculated.

In contrast to thermal profiles measured in 2008 and 2009 , no discrete cold-water anomalies were measured during the 2018 surveys (fig. 23). Diffuse groundwater discharge to the Chandler Reach, however, was supported by the detrended water temperatures of less than the start of the survey for much of the 2009 and 2018 thermal profiles (figs. 22, 23) and groundwater gains of 0.23 and $0.57 \mathrm{~m} / \mathrm{s} / \mathrm{km}$ (13.3 and 32.2 $\mathrm{ft}^{3} / \mathrm{s} / \mathrm{mi}$ ) recorded by 1999 and 2004 seepage runs (Magirl and others, 2009). In addition to diffuse groundwater discharge throughout the reach, several discrete cold-water anomalies associated with inputs such as Knox Creek (RM 34.4) and Corral Canyon Creek (RM 33.6), which convey water from irrigated uplands to the north of the Chandler Reach, were measured during the 2008 and 2009 surveys; however, these river sections were not measured during the 2018 survey, potentially because the temperature sensor was not close to these locations. An additional cold-water anomaly associated with a groundwater seep was measured at RM 32.4 during the 2009 survey. 
A. September 13, 2018 channel left

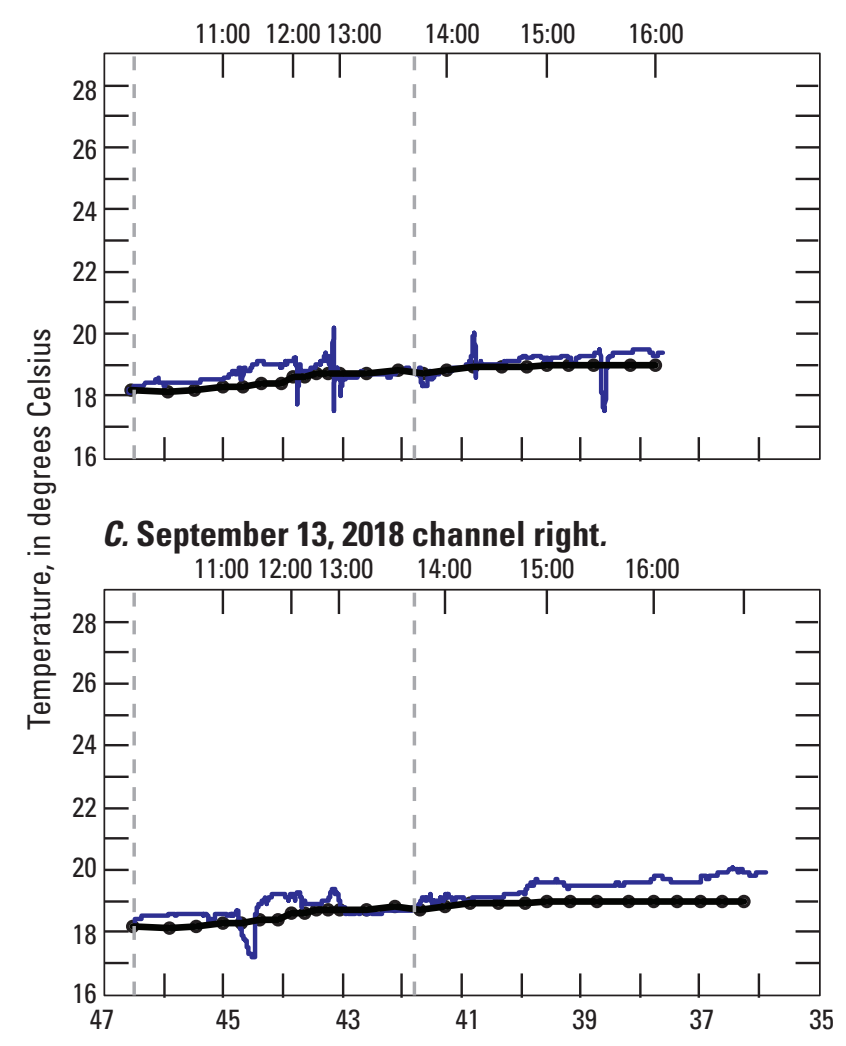

B. September 13, 2018 channel left

Time

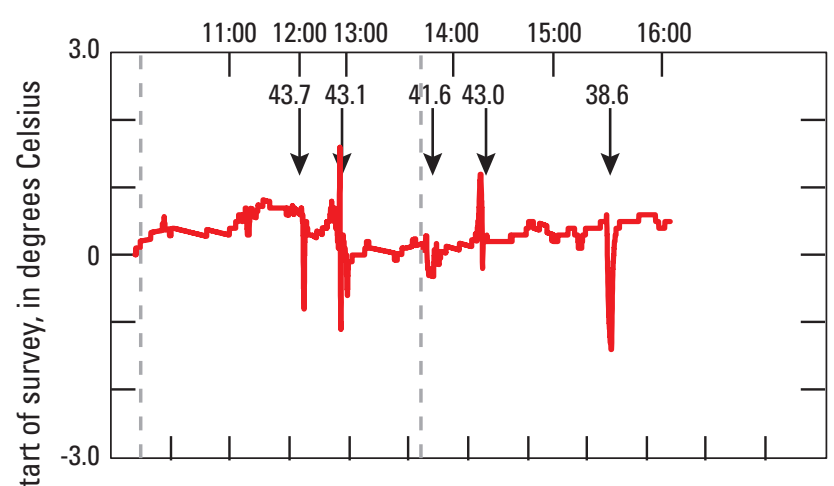

\section{September 13, 2018 channel right}

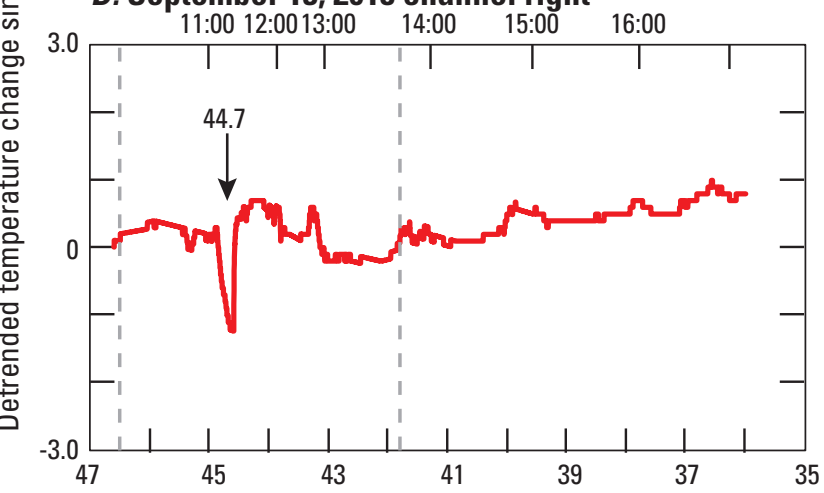

River mile

\section{EXPLANATION}

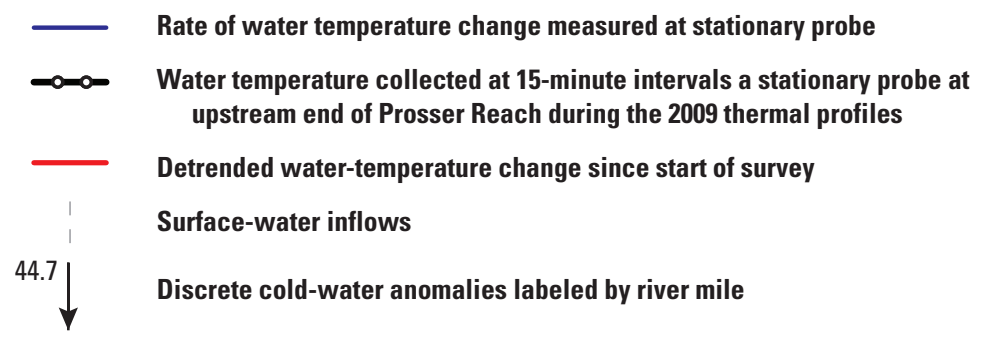

Figure 20. Thermal profiles and rate of water-temperature change of channel left $(A$ and $B)$ and channel right $(C$ and $D)$, Prosser Reach, Yakima River, Washington, September 13, 2018. 
August 19, 2008 channel center

Time

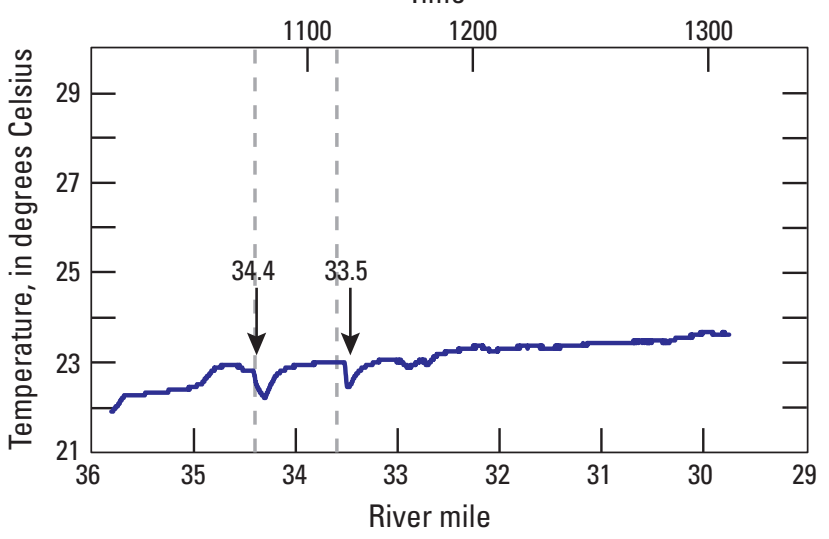

EXPLANATION

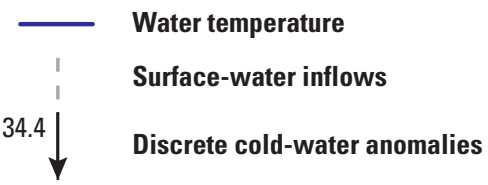

Figure 21. Thermal profiles of channel center of Chandler Reach, Yakima River, Washington, August 19, 2008.

\section{Benton Reach (River Miles 30-19)}

Thermal profiles of the Benton Reach, which begins at Benton City (RM 29.7) and ends at Horn Rapids diversion dam (RM 18.7), were surveyed in 2008, 2009, and 2018 (figs. 24, 25, 26). Like the Prosser and Chandler Reaches immediately upstream, the Benton Reach had a high water-surface gradient $(0.0008 \mathrm{~m} / \mathrm{m})$ that was controlled by near-surface basalt bedrock of the Saddle Mountain Basalt. The channel and alluvial aquifer are largely limited to a narrow corridor by terraces formed by Touchet Beds and basalt bedrock (fig. 7). A series of high-gradient rapids separate low-gradient pools within the Benton Reach (fig. 27). Vaccaro and others (2009) documented river stage above the water table within most of this reach, which was consistent with seepage losses net of surface-water inflows and diversions of $-0.32 \mathrm{~m} / \mathrm{s} / \mathrm{km}$ $(-18.2 \mathrm{ft} 3 / \mathrm{s} / \mathrm{mi}$ ) measured in 2004 (Magirl and others, 2009). Stationary probes at the upstream end of the reach measured an average warming rate of $0.0040{ }^{\circ} \mathrm{C} /$ minute $\left(0.24{ }^{\circ} \mathrm{C} /\right.$ hour $)$ during the 2009 survey and an average warming rate of 0.015
${ }^{\circ} \mathrm{C} /$ minute $\left(0.91{ }^{\circ} \mathrm{C} /\right.$ hour $)$ during the 2018 survey. No stationary probes were deployed during the 2008 survey and the corresponding rate of warming was not calculated.

Evidence of diffuse cold-water anomalies was largely absent from the 2009 thermal profiles of the Benton Reach and except between RM 27.2 and 26.8, detrended water temperatures were higher than the start of the 2009 survey (fig. 25F). In contrast, detrended water temperatures were lower than the start of the survey, and decreasing, during the 2018 surveys downstream of RM 28 (fig. 26), suggesting diffuse cold-water anomaly for much of the reach. The detection of these diffuse cold-water anomalies in 2018 may partly reflect a higher rate of diurnal warming in 2018 versus 2009, resulting in increased contrast between groundwater and surface water in 2018 . Discrete cold-water anomalies were largely absent from the Benton Reach except for a side channel at RM 28.0, which was measured in all 3 years of surveys, suggesting a consistent source of groundwater discharge at this location through a spring or seep. An additional cold-water anomaly was measured during the 2008 and 2009 surveys at RM 26.1, which was associated with a small, unnamed tributary where cool surface water and associated groundwater may discharge into the Yakima River.

\section{Snively Reach (River Miles 16-6)}

The Snively Reach begins about 1.8 miles downstream of Horn Rapids diversion dam at RM 16.2 and flows through an alluvial floodplain that is less constrained by bedrock compared to the Benton Reach immediately upstream. Mean gradient of the Snively Reach was $0.0007 \mathrm{~m} / \mathrm{m}$. Although several vegetated islands divide the channel in the Snively Reach, few exposed gravel bars occur within the active channel. Evidence of former channel migration and avulsion, including abandoned channels and scroll bars, is present within the floodplain, but recent channel migration was limited compared to the most upstream reaches of the study area such as the Parker, Toppenish, and Granger Reaches. The margins of the alluvial floodplain are mostly terraces formed by glacial outburst flood deposits (Reidel and Fecht, 1994). Rural and suburban residential development and irrigated agricultural lands are the predominant landcovers adjacent to the Snively Reach and the Columbia Irrigation District Canal, which begins at Horn Rapids diversion dam and follows the right bank of the Yakima River throughout the Snively Reach. 
A. July 28, 2009 channel left
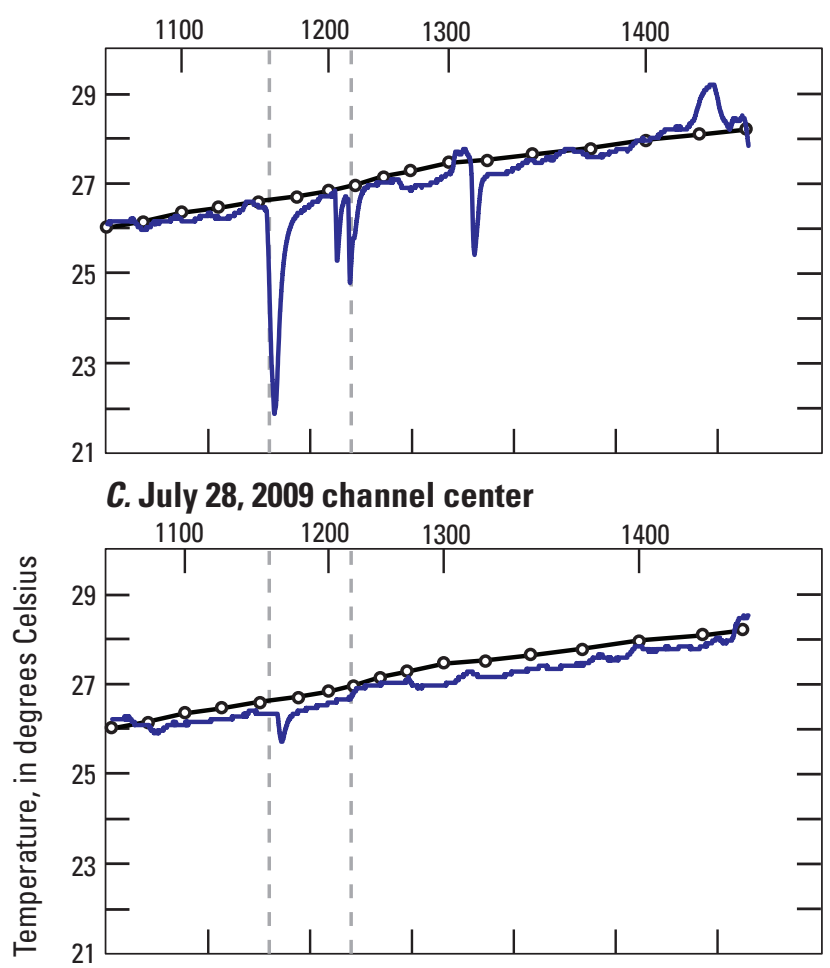

E. July 28, 2009 channel right

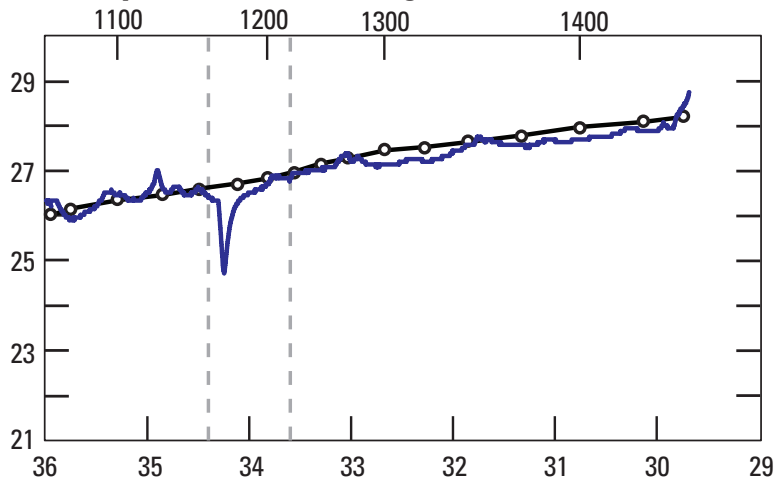

\section{B. July 28, 2009 channel left}

Time

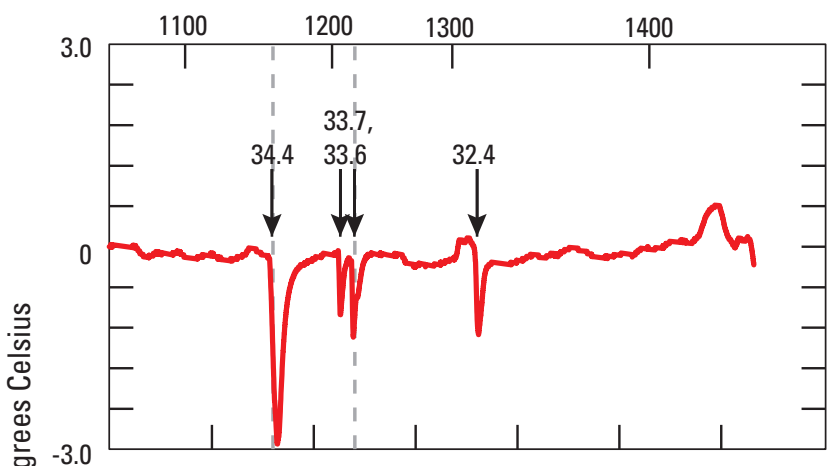

D. July 28, 2009 channel center

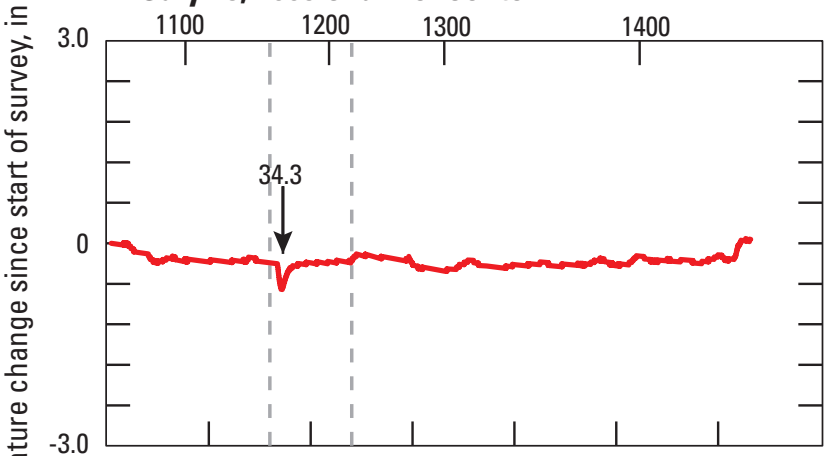

F. July 28, 2009 channel right

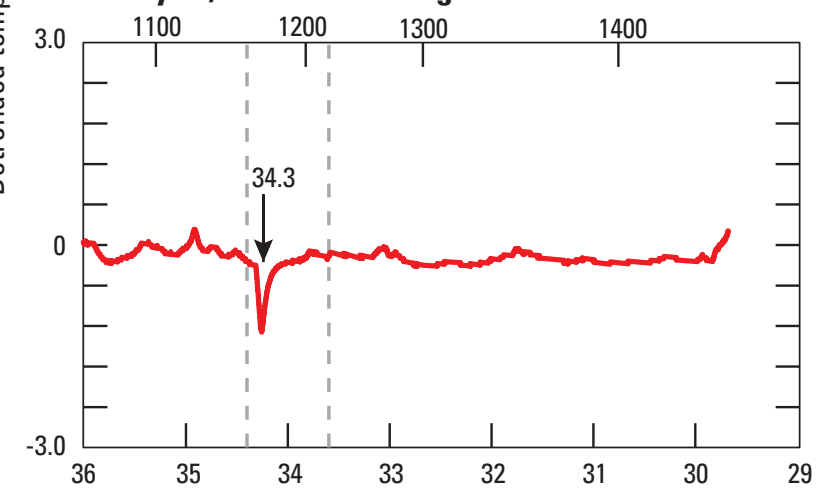

River mile

EXPLANATION

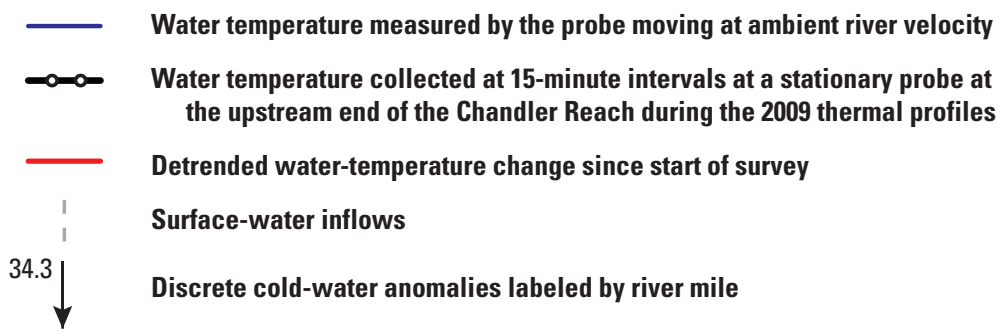

Figure 22. Thermal profiles and detrended temperature change, since the start of survey, of channel left $(A$ and $B)$, channel center $(C$ and $D)$, and channel right ( $E$ and $F$, Chandler Reach, Yakima River, Washington, July 28, 2009. 


\section{A. July 18, 2018 channel left}

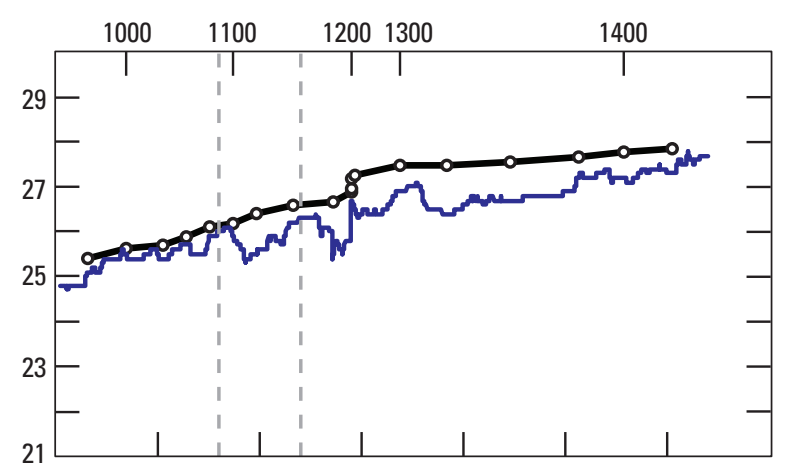

C. July 18, 2018 channel center

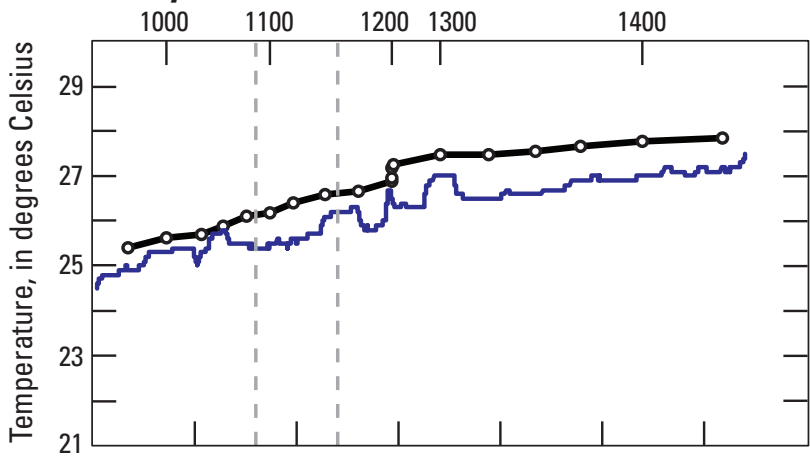

E. July 18, 2018 channel right

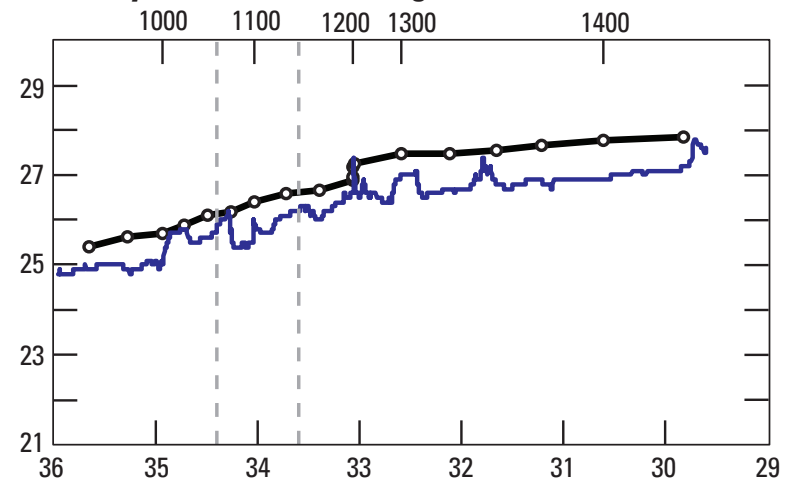

\section{B. July 18, 2018 channel left}

Time

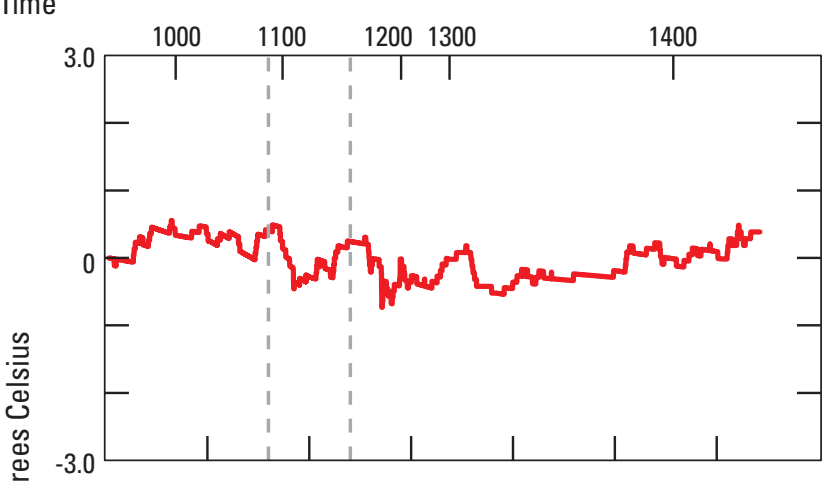

\section{July 18, 2018 channel center}

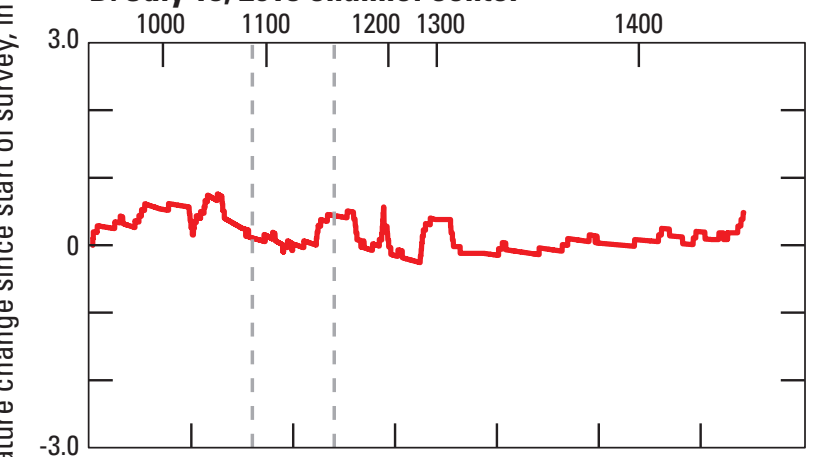

\section{F. July 18, 2018 channel right}

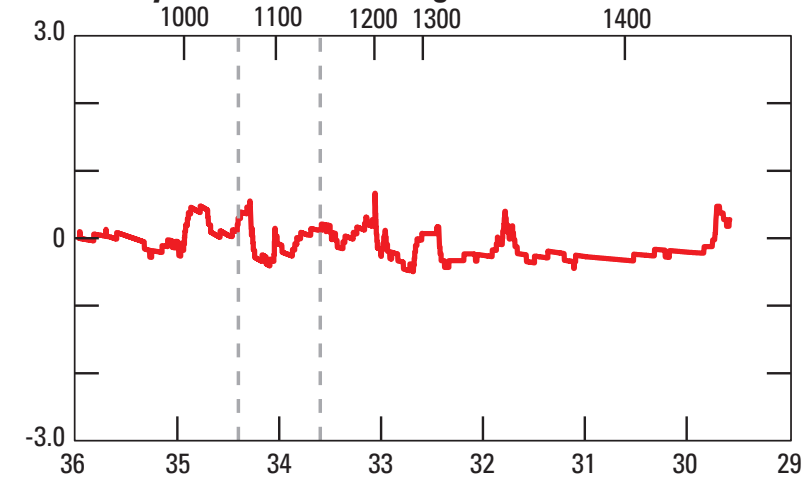

River mile

\section{EXPLANATION}

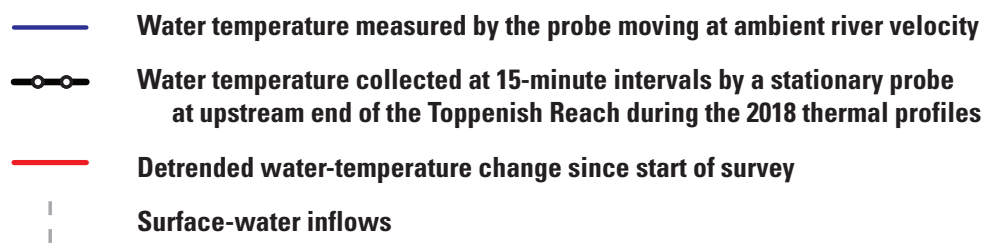

Figure 23. Thermal profiles and detrended temperature change, since the start of survey, of channel left $(A$ and $B)$, channel center $(C$ and $D)$, and channel right $(E$ and $F$, Chandler Reach, Yakima River, July 18, 2018. 


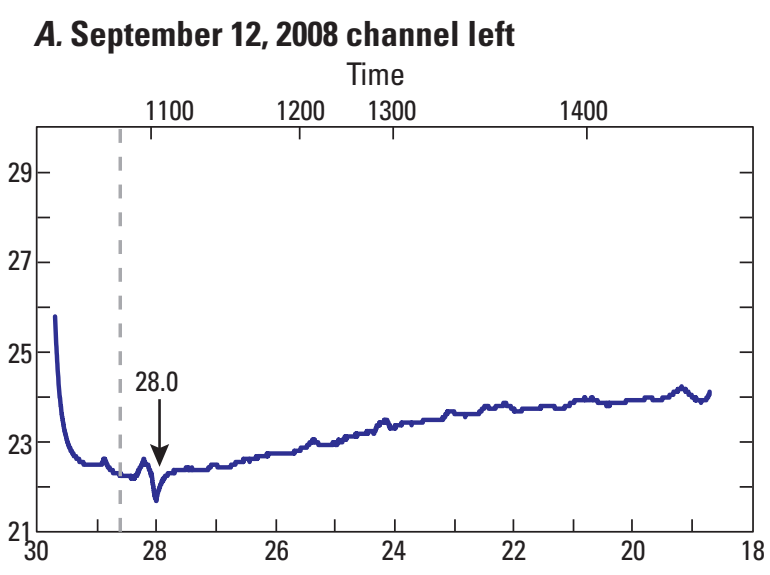

B. September 12, 2008 channel center
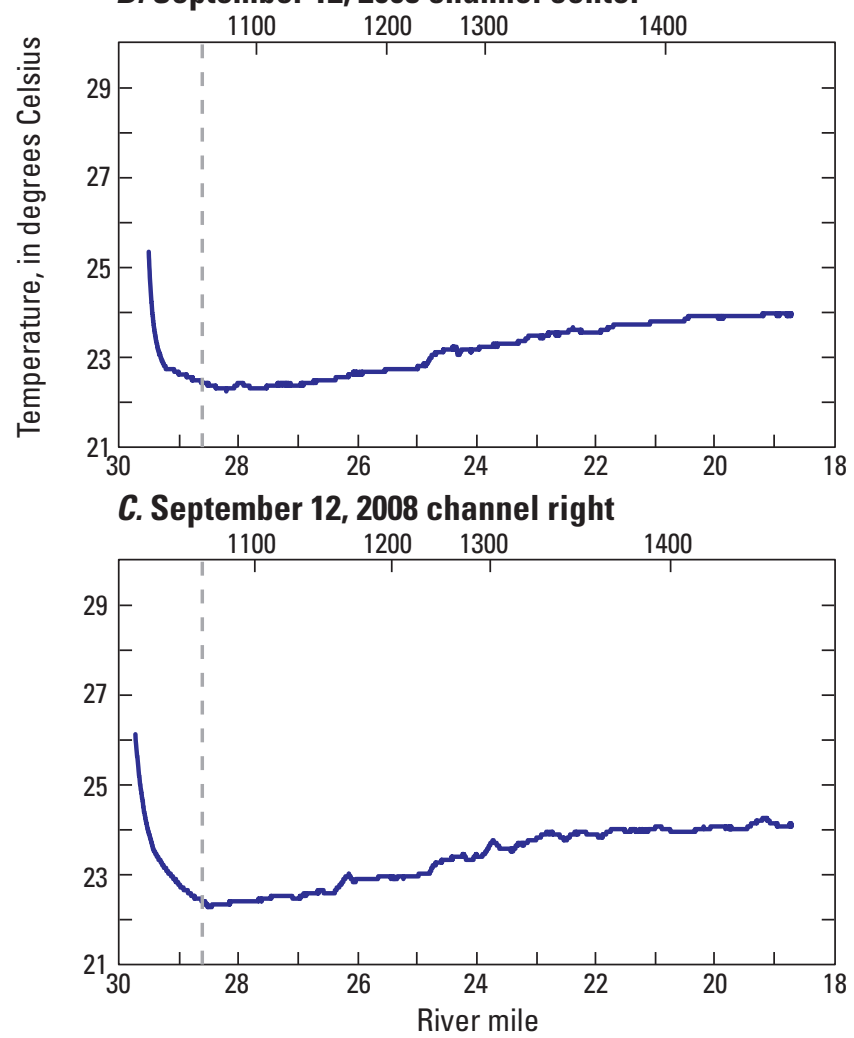

EXPLANATION
Thermal profiles of the Snively Reach were measured in 2008, 2009, and 2018 (figs. 28, 29, 30). Stationary probes at the upstream end of the reach measured an average warming rate of $0.0085^{\circ} \mathrm{C} /$ minute $\left(0.51^{\circ} \mathrm{C}\right.$ /hour $)$ during the 2009 survey and an average warming rate of $0.0096^{\circ} \mathrm{C} /$ minute $(0.57$ ${ }^{\circ} \mathrm{C}$ /hour) during the 2018 survey. No stationary probes were deployed during the 2008 survey and the corresponding rate of warming was not calculated. Although streamflow losses net of surface-water inflows and diversions were identified by 2004 and 1988 seepage runs between RM 29.9 and RM 8.4 (Magirl and others, 2009), which includes the Snively and Benton Reaches, several localized zones of discrete cold-water anomalies were measured during the thermal surveys. Most discrete cold-water anomalies occurred within the channel-left and channel-right profiles where groundwater seepage and other cold-water inputs mixed more slowly with upstream water. A discrete cold-water anomaly was present at the start of each profile at RM 16.2 during all 3 years of surveys (figs. $28,29,30$ ); while this anomaly persisted in the channel left profile of the 2018 survey, the channel-center and -right profiles of the 2018 surveys warmed immediately downstream as warm upstream water mixed with colder groundwater discharge. A second discrete cold-water anomaly was measured during the 2018 channel-left survey from RM 15.4 to 15.1 and also occurs, to a lesser degree, in the channel-center and -right profiles of the 2018 survey. Several seeps were observed during the surveys at these locations contributing groundwater discharge to the river. These seeps may have been associated with recharge from irrigation canal leakage and irrigated agricultural land in the river corridor. Water from a small wasteway that collected colder groundwater discharge from adjacent irrigated fields contributed to a cold-water anomaly on channel right RM 14.5 that was measured during all survey years. Additional cold-water anomalies were delineated from the 2018 surveys at RM 14.9, 14.5, 14.2, 13.9, and 11.1, but they were not present in surveys from other years. Diffuse cold-water anomalies were absent from the 2009 thermal surveys but detrended water temperatures from the 2018 surveys downstream of RM 15 were lower than the start of the survey suggesting diffuse cold-water anomaly for much of the reach (fig. 30).

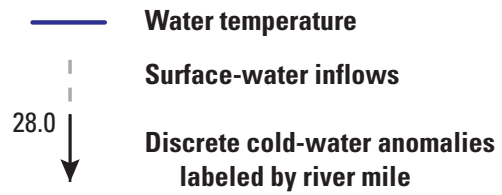

Figure 24. Thermal profiles of channel left (A), channel center (B), and channel right (C), Benton Reach, Yakima River, Washington, August 12, 2008. 
A. July 29, 2009 channel left

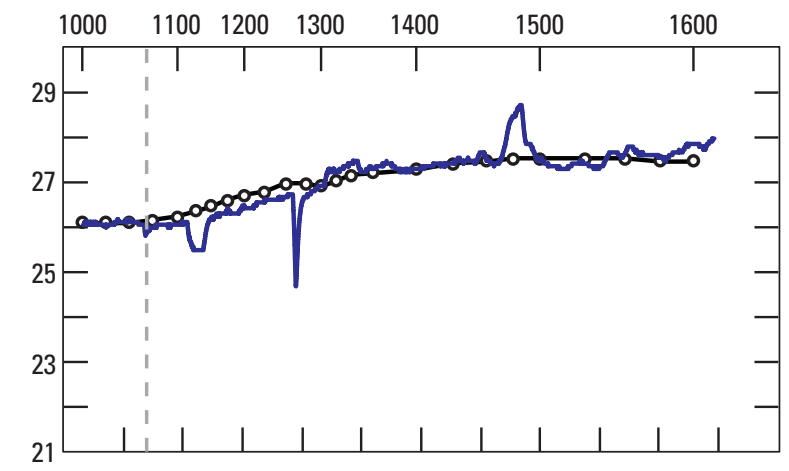

C. July 29, 2009 channel center

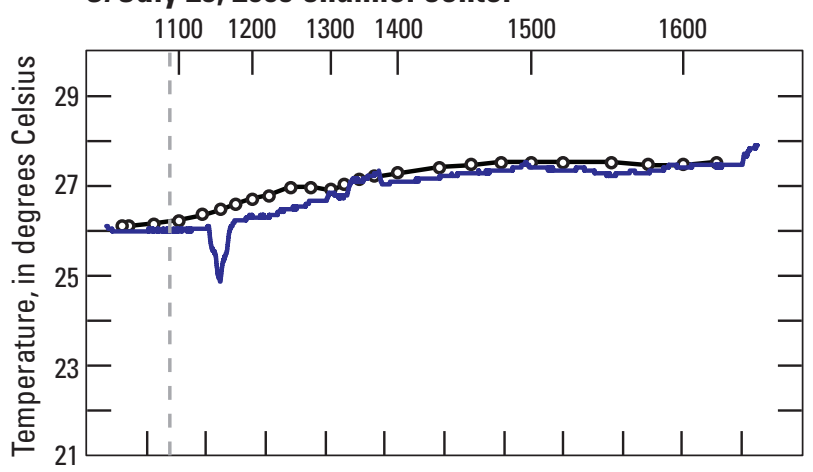

E. July 29, 2009 channel right

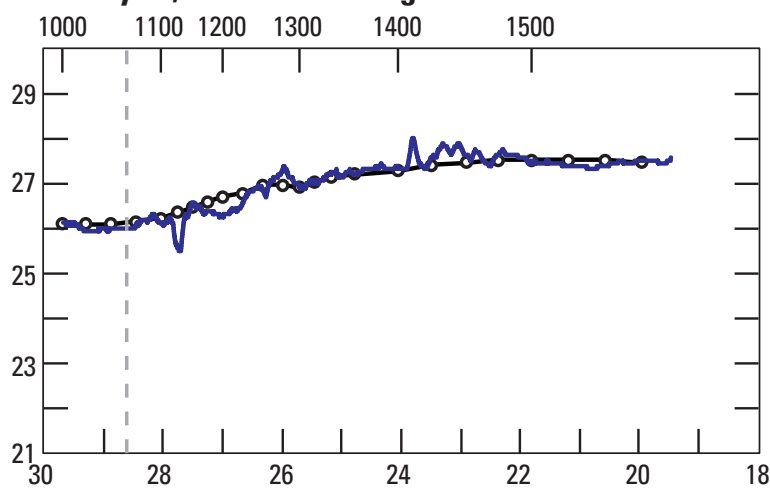

B. July 29, 2009 channel left

Time
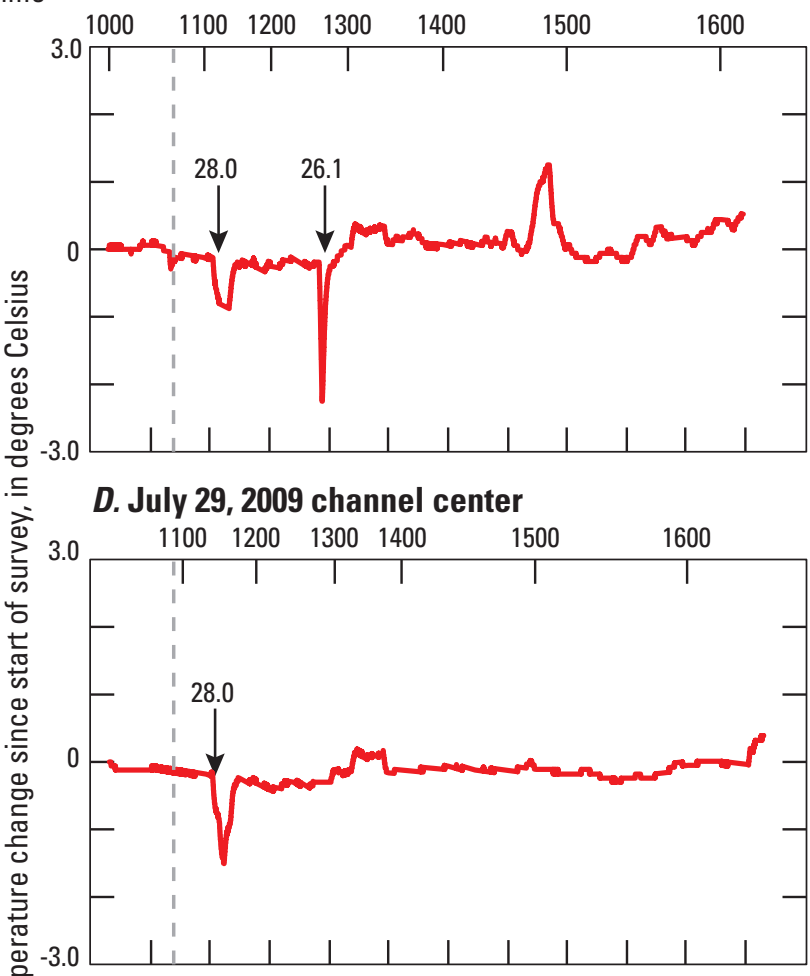

\section{F. July 29, 2009 channel right}

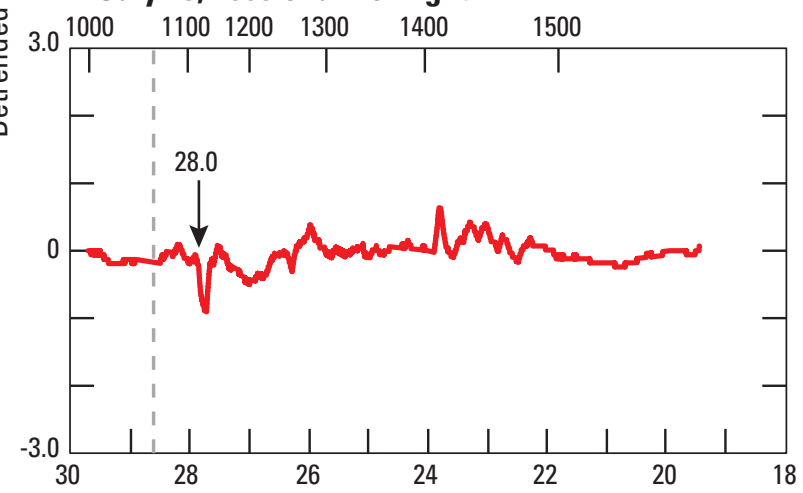

River mile

\section{EXPLANATION}

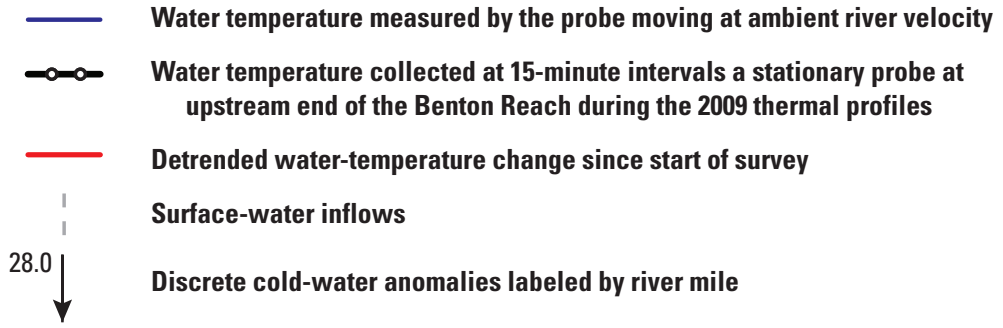

Figure 25. Thermal profiles and detrended temperature change, since the start of survey, of channel left $(A$ and $B)$, channel center ( $C$ and $D)$, and channel right ( $E$ and $F$, Benton Reach, Yakima River, Washington, July 29, 2009. 
A. July 27, 2018 channel left

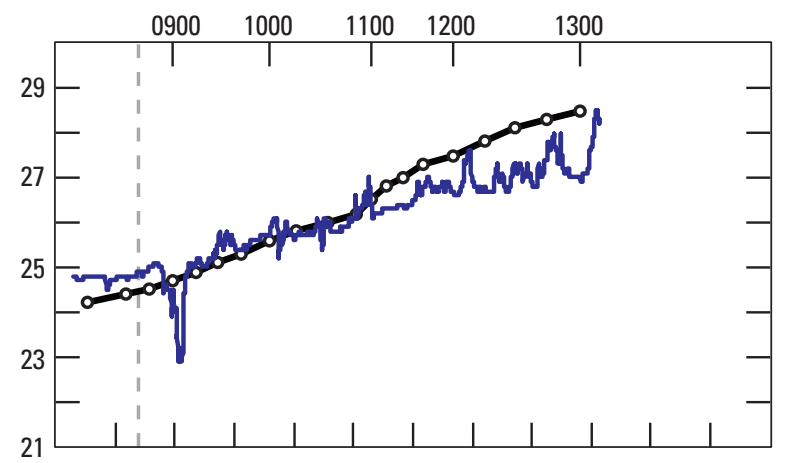

C. July 27, 2018 channel center

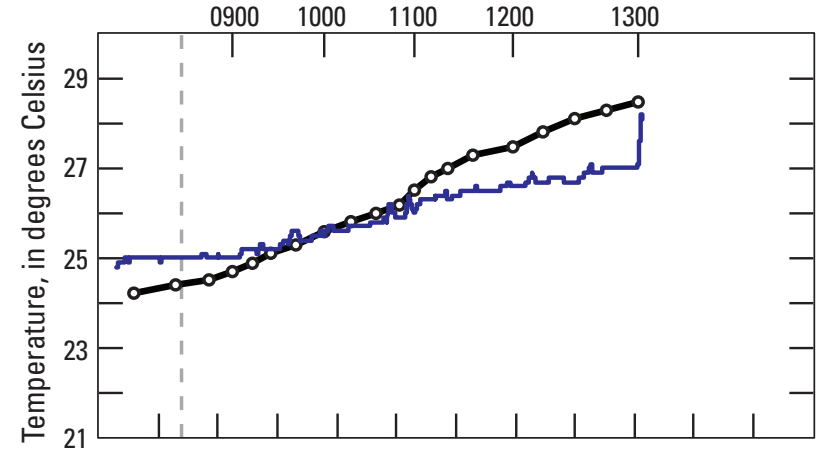

E. July 27, 2018 channel right

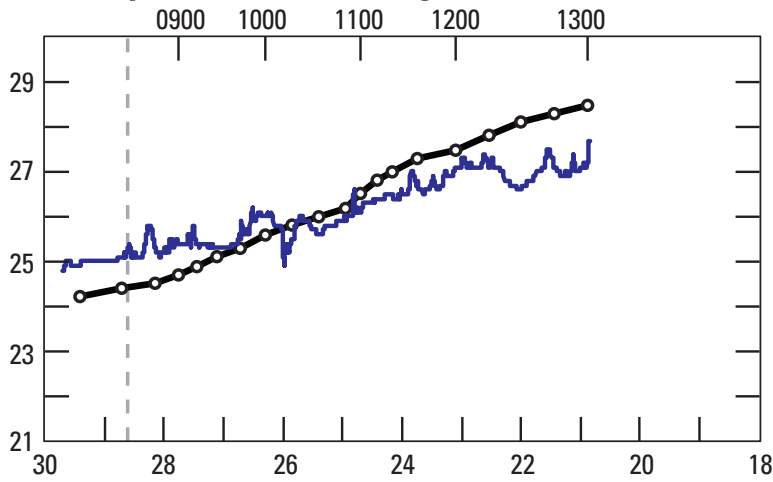

B. July 27,2018 channel left

Time

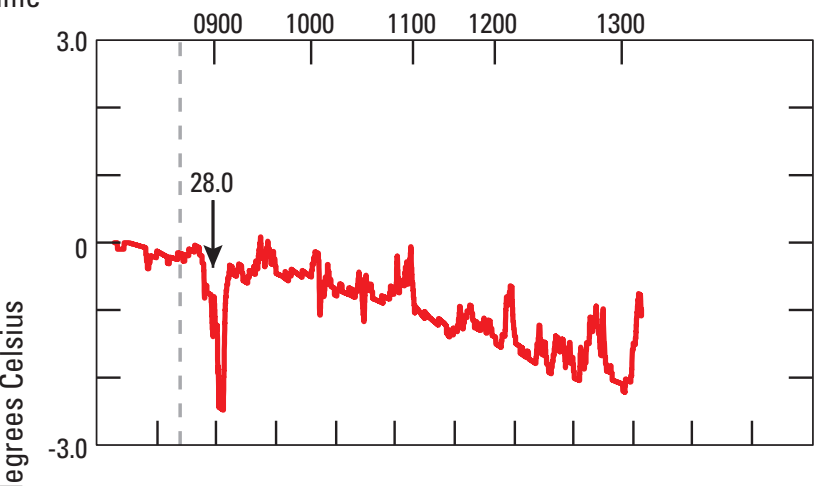

D. July 27, 2018 channel center

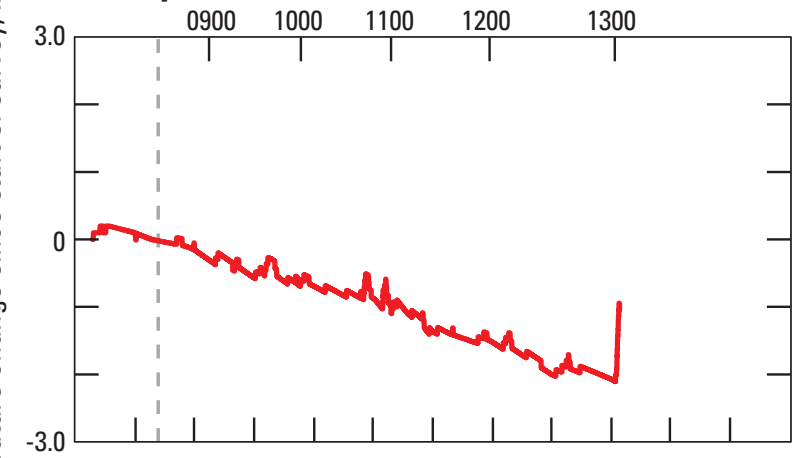

F. July 27, 2018 channel right

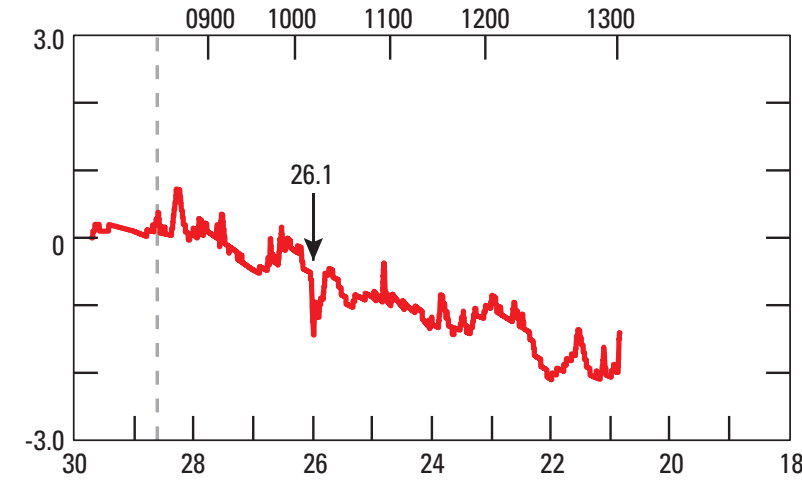

River mile

\section{EXPLANATION}

Water temperature measured by the probe moving at ambient river velocity
$\begin{array}{r}\text { Water temperature collected at 15-minute intervals a stationary probe at } \\ \text { upstream end of the Benton Reach during the } 2018 \text { thermal profiles }\end{array}$
Detrended water-temperature change since start of survey
Surface-water inflows
Discrete cold-water anomalies labeled by river mile

Figure 26. Thermal profiles and detrended temperature change, since the start of survey, of channel left (A and $B)$, channel center (C and D), and channel right (E and F), Benton Reach, Yakima River, Washington, July 27, 2018. 

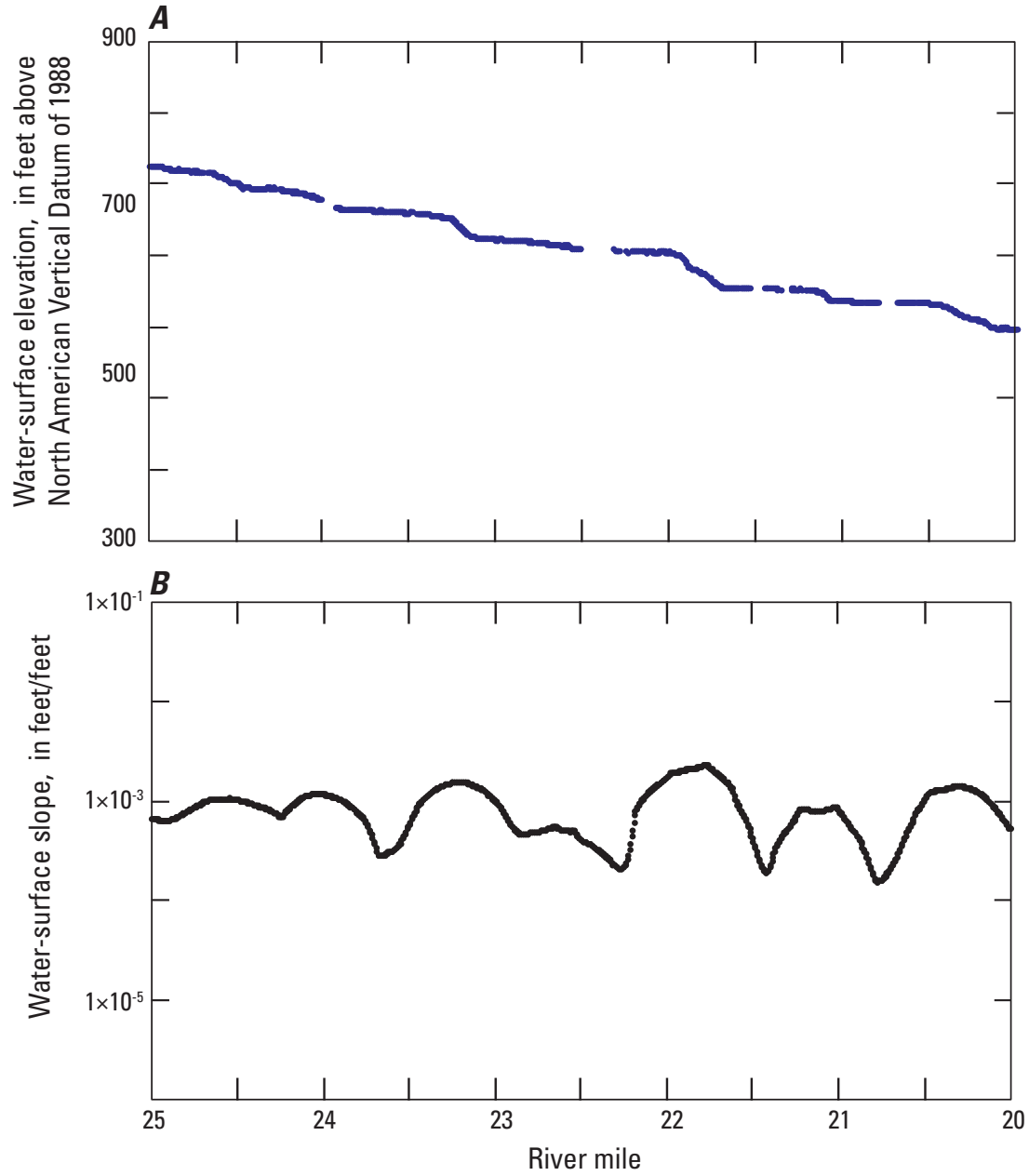

EXPLANATION

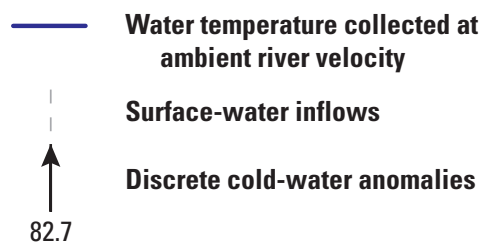

Figure 27. Longitudinal profiles of water-surface elevation and gradient between river miles 25 and 20, Yakima River, Washington, May-June 2015. Data derived from lidar imagery. 


\section{A. August 13, 2008 channel left}

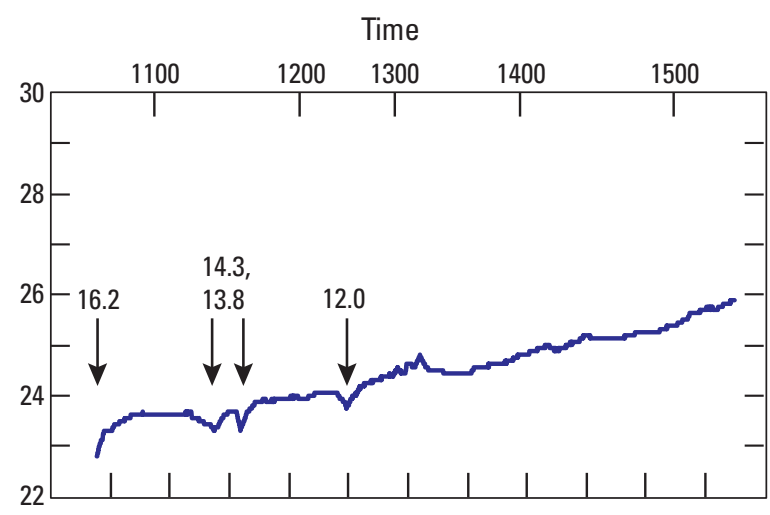

\section{B. August 13, 2008 channel center}

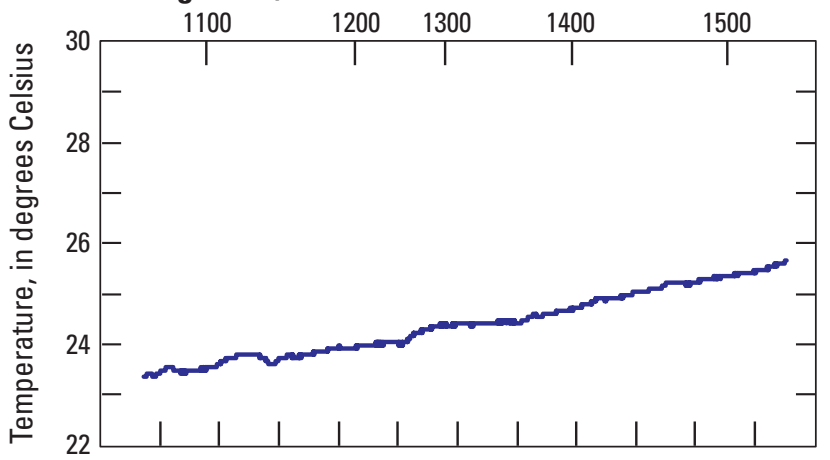

C. August 13, 2008 channel right

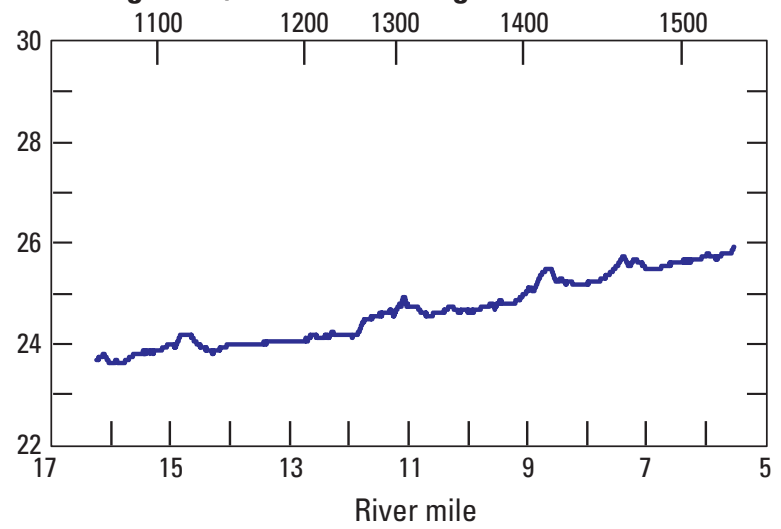

EXPLANATION

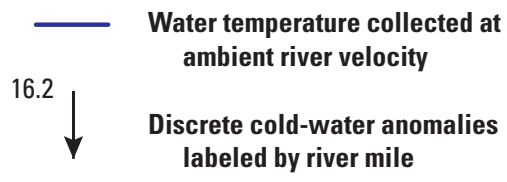

Figure 28. Thermal profiles of channel left $(A)$, channel center $(B)$, and channel right $(C)$, Snively Reach, Yakima River, Washington, August 13, 2008.

\section{Confluence Reach (River Miles 9-0)}

The Confluence Reach, which extends from RM 8.7 to 0 , flows through suburban and urban areas of Richland and West Richland where development is mostly present on terraces above both sides of the modern floodplain. The Columbia Irrigation District Canal and irrigated agricultural land are also present adjacent to the river and within the floodplain as in the Snively Reach immediately upstream. The downstream end of the Confluence Reach flows through an undeveloped delta managed by the U.S. Army Corps of Engineers at the confluence of the Yakima and Columbia Rivers. Although evidence of historical channel migration such as former meander bends is present in the present floodplain of the Confluence Reach, modern channel migration is restricted by levees and revetements as well as a low water-surface gradient that averaged $0.0006 \mathrm{~m} / \mathrm{m}$, partly due to backwater of the Columbia River, which is locally regulated by McNary Dam. Additionally, the Bateman Island Causeway, an engineered earthen berm, connects Richland to Bateman Island and forms a complete barrier to flow between the Yakima and Columbia Rivers at the southern end of Bateman Island that contributes to elevated water temperature in the immediate vicinity of the confluence of the Yakima and Columbia Rivers (Holroyd, 1998). Modification of the Bateman Island Causeway to allow mixing and to decrease water temperatures in the Yakima River delta is currently under review by the U.S. Army Corps of Engineers as part of a larger environmental restoration project in the delta with a primary goal of habitat enhancement for salmonids. Although few gravel bars exist in this reach, several stable, vegetated islands divide the Yakima River's channel in the Confluence Reach. No information about seepage gains and losses were available for this reach. 


\section{A. July 30, 2009 channel left}

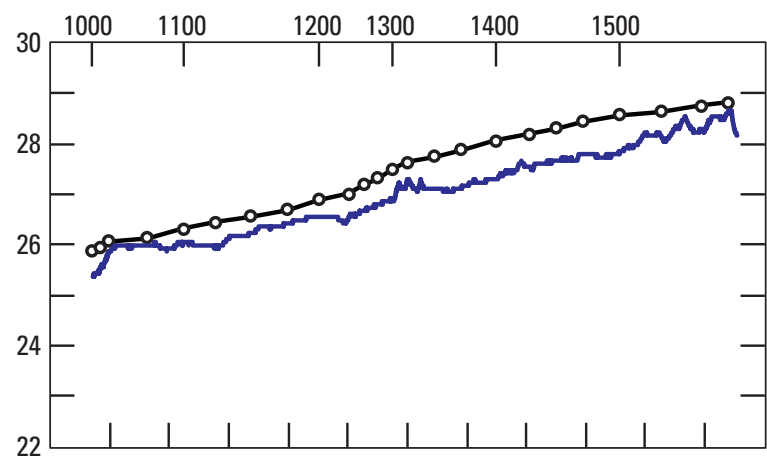

C. July 30, 2009 channel center

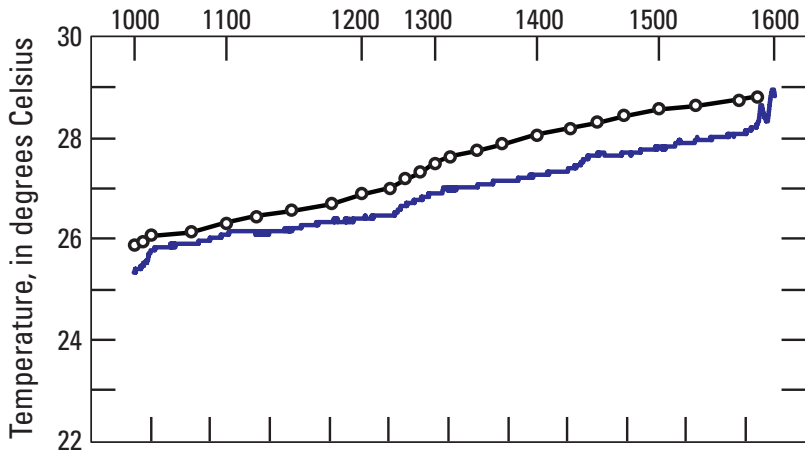

\section{E. July 30, 2009 channel right}

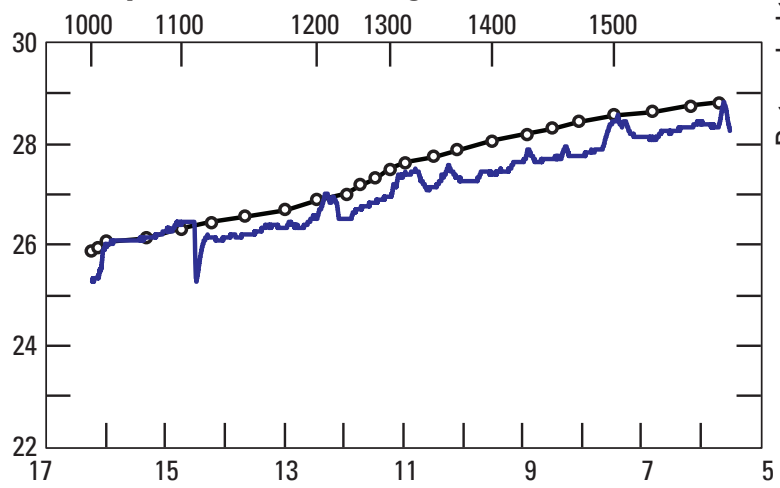

\section{B. July 30, 2009 channel left}

Time

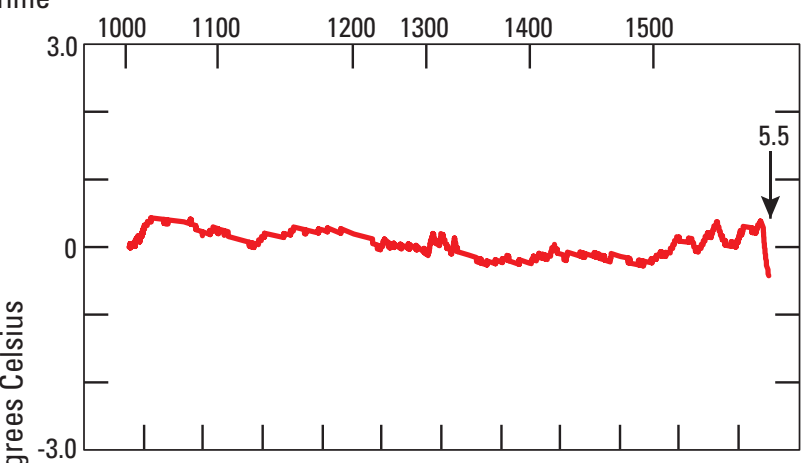

\section{July 30, 2009 channel center}

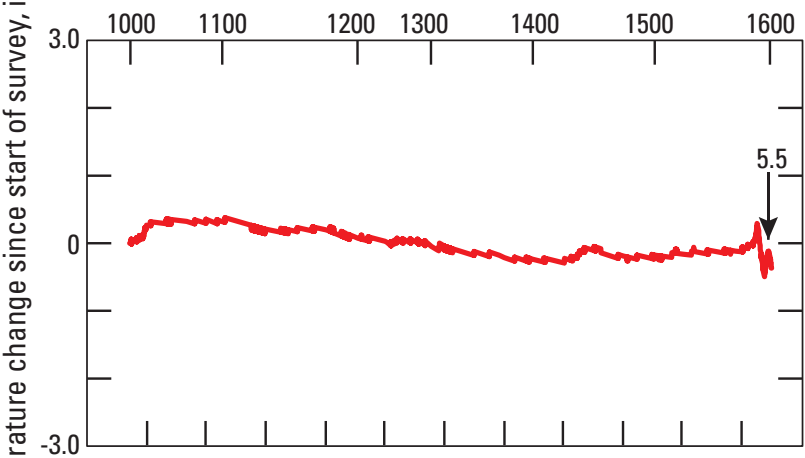

F. July 30, 2009 channel right

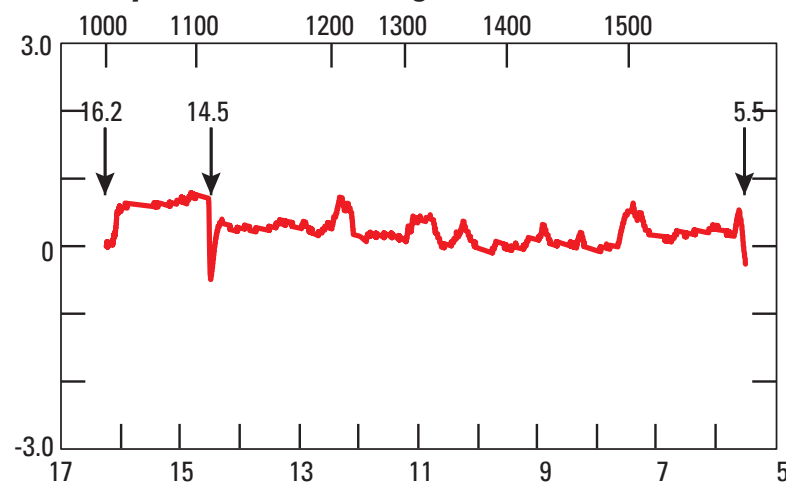

River mile

\section{EXPLANATION}

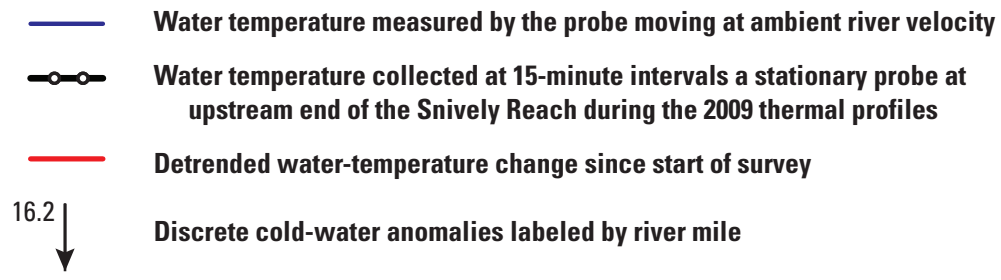

Figure 29. Thermal profiles and detrended temperature change, since the start of survey, of channel left (A and B), channel center (C and D), and channel right (E and F), Yakima River, Washington, July 30, 2009. 


\section{A. July 19, 2018 channel left}

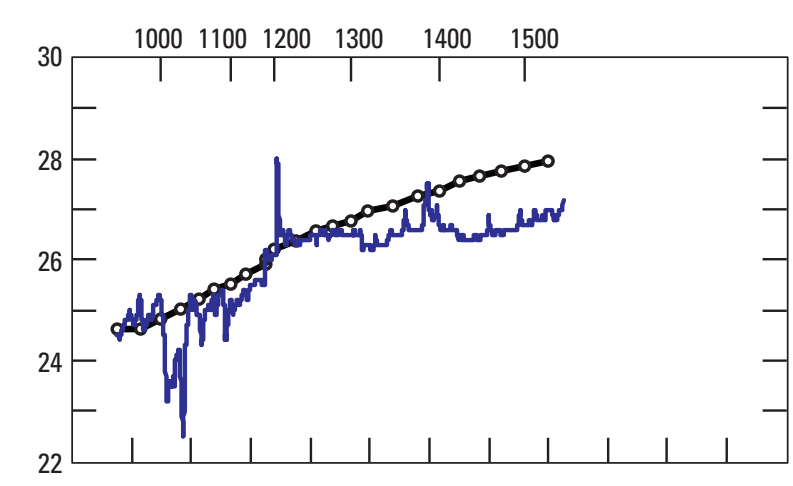

\section{July 19, 2018 channel center}

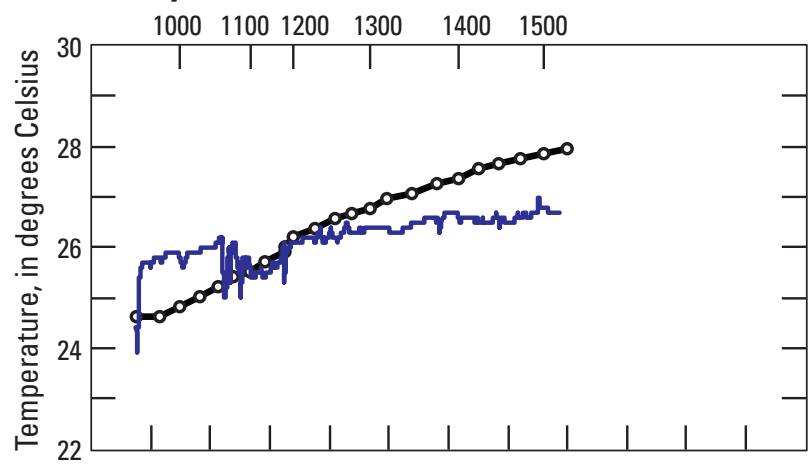

E. July 19, 2018 channel right

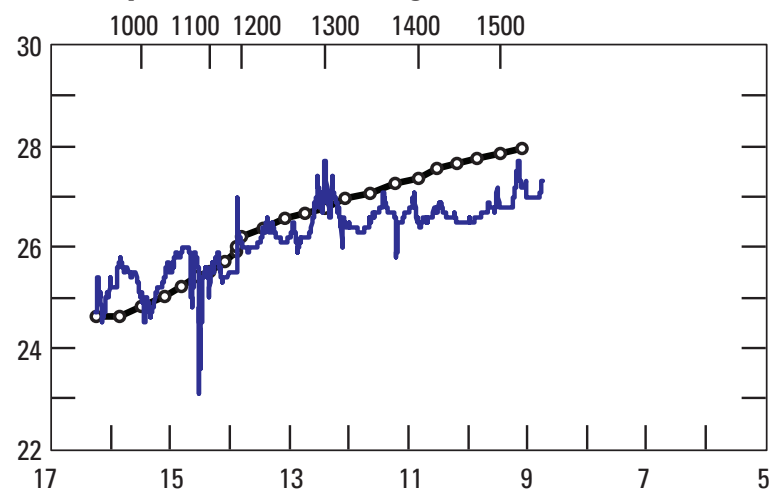

\section{B. July 19, 2018 channel left}

Time

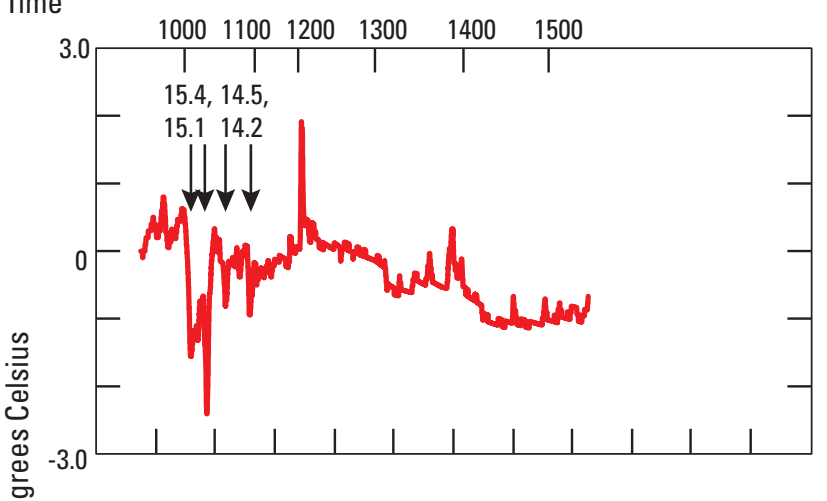

D. July 19, 2018 channel center

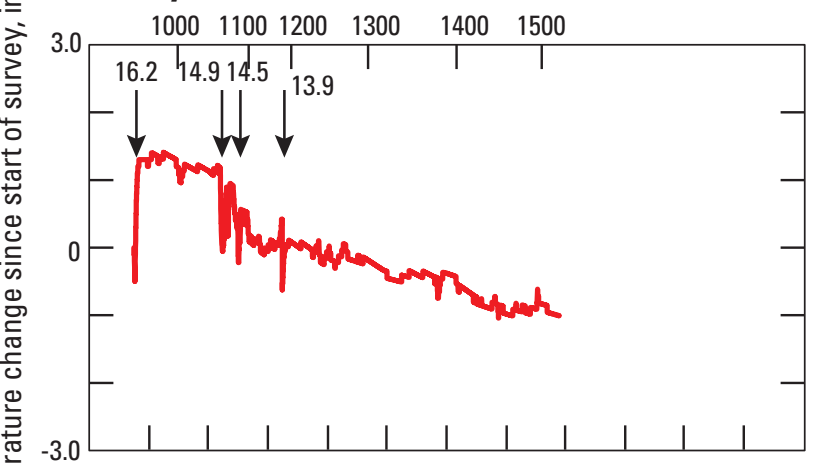

$-3.0$

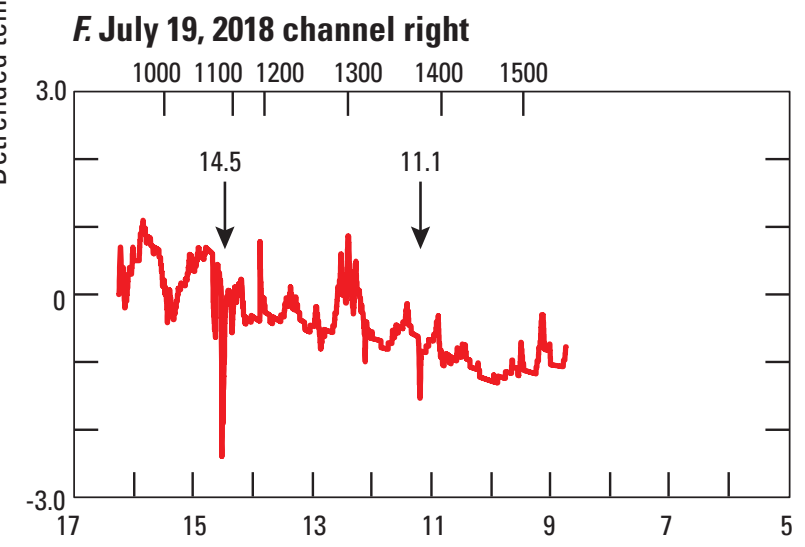

River mile

\section{EXPLANATION}

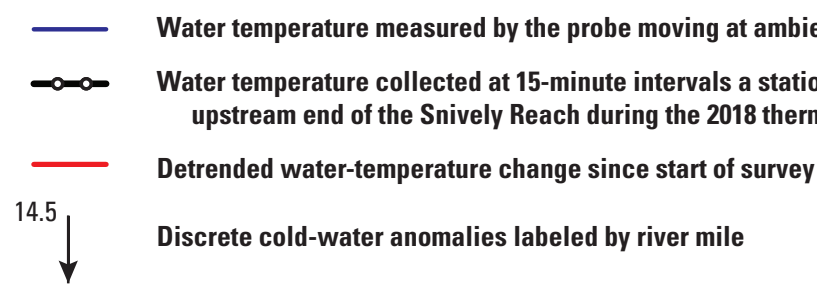

Figure 30. Thermal profiles and detrended temperature change, since the start of survey, of channel left $(A$ and $B)$, channel center $(C$ and $D)$, and channel right ( $E$ and F), Snively Reach, Yakima River, Washington, July 19, 2018. 
Thermal profiles of the left, center, and right channel of the Confluence Reach were measured in 2008, 2009, and 2018 (fig. 31, 32, 33). Stationary probes at the upstream end of the reach measured an average warming rate of $0.0095^{\circ} \mathrm{C} /$ minute $\left(0.54^{\circ} \mathrm{C} /\right.$ hour $)$ during the 2009 survey and an average warming rate of $0.0088^{\circ} \mathrm{C} /$ minute $\left(0.53{ }^{\circ} \mathrm{C} /\right.$ hour $)$ during the 2018 survey. No stationary probes were deployed during the 2008 survey and the corresponding rate of warming was not calculated. Numerous discrete cold-water anomalies were measured during the 2018 surveys, and most occurred along channel right where cold-water inputs from irrigation returns and groundwater discharge were present. Groundwater discharge on the right bank may result from the elevated groundwater levels in surficial aquifers due to leakage from the irrigation canal and residential irrigation along the right bank (Vaccaro, 2011). Steep groundwater gradients toward the Yakima River within the Confluence Reach were interpreted from measured groundwater levels within both the surficial aquifer and the Saddle Mountains Basalt by Vaccaro and others (2009). Several discrete cold-water anomalies were associated with alcoves formed at the downstream end of gravel bars where groundwater discharge does not readily mix with upstream water and remains cold (for example, RM 8.5, RM 7.4, RM), others are located at bank seeps and springs (for example, RM 6.2 and RM 4.7), or at the outlet of wasteways that convey irrigation returns (for example, RM 2.6 at the Amon Wasteway). These sites are of particular importance as potential cold-water refuges for migrating salmonids because they are the most downstream cold-water anomalies surveyed in the lower Yakima River. In addition to discrete cold-water anomalies within the Confluence Reach, several diffuse coldwater anomalies were present in the 2009 and 2018 thermal profiles downstream of between RM 5 and RM 1.5 as evidenced by detrended water temperatures that were lower than the start of the survey. 


\section{A. 08/14/2008 channel left}

Time

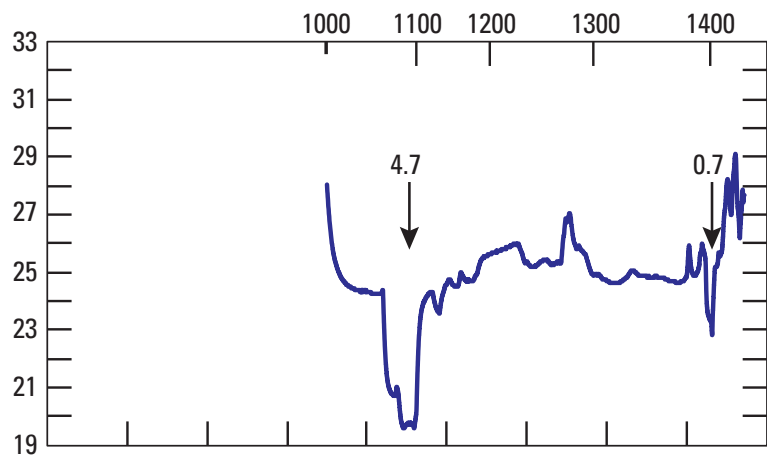

B. 08/14/2008 channel center
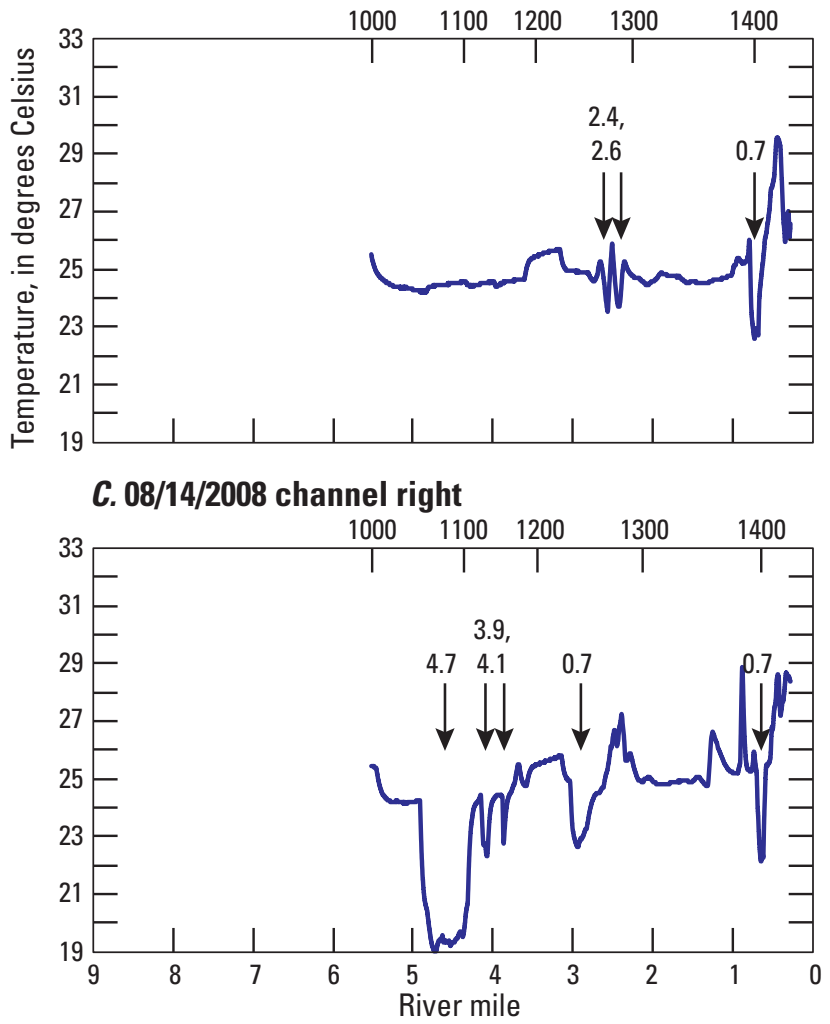

EXPLANATION

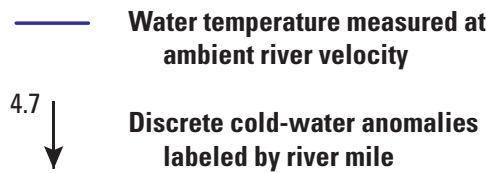

Figure 31. Thermal profiles of channel left $(A)$, channel center $(B)$, and channel right $(C)$, Confluence Reach, Yakima River, August 14, 2008. 


\section{A. July 31, 2009 channel left}

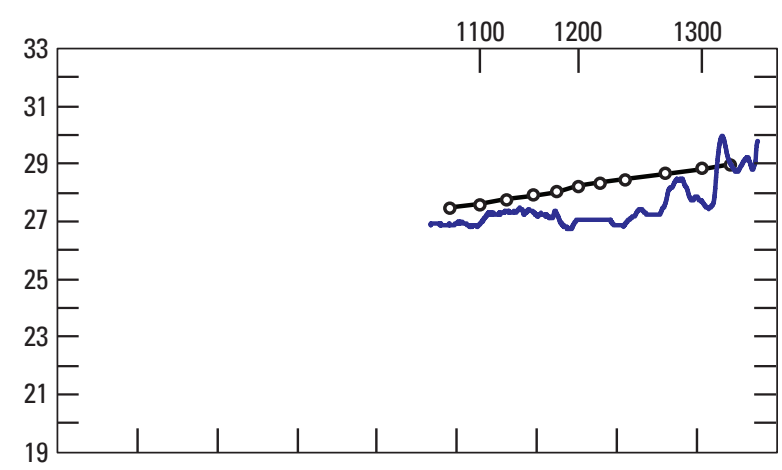

\section{July 31, 2009 channel center}

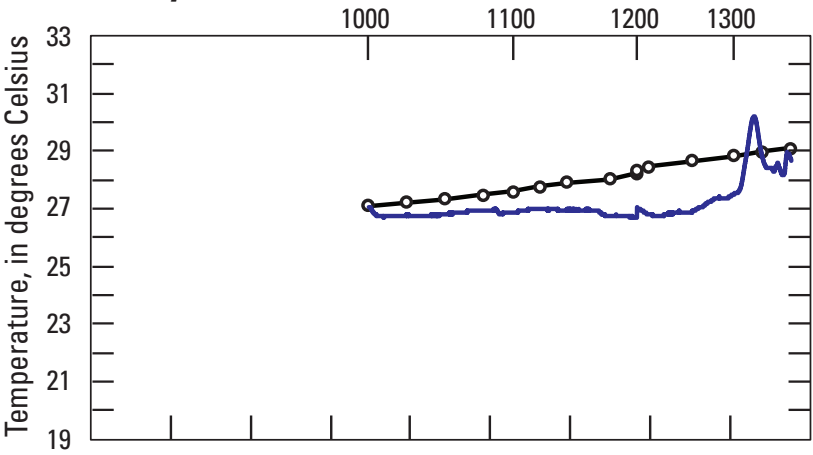

\section{E. July 31, 2009 channel right}

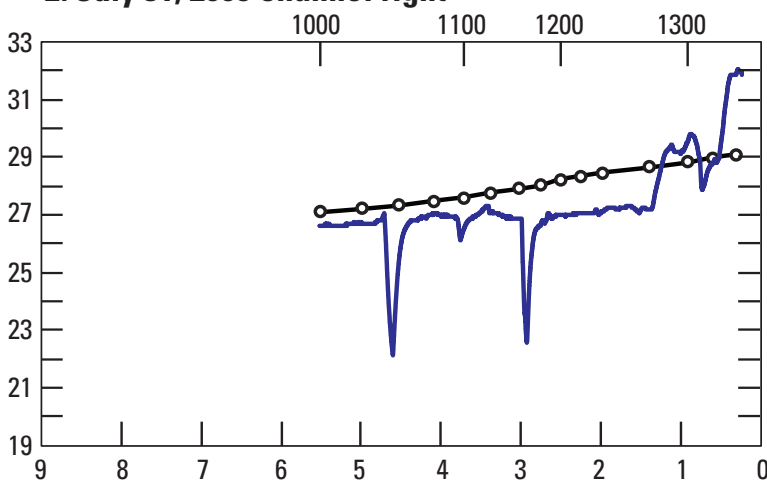

\section{B. July 31, 2009 channel left}
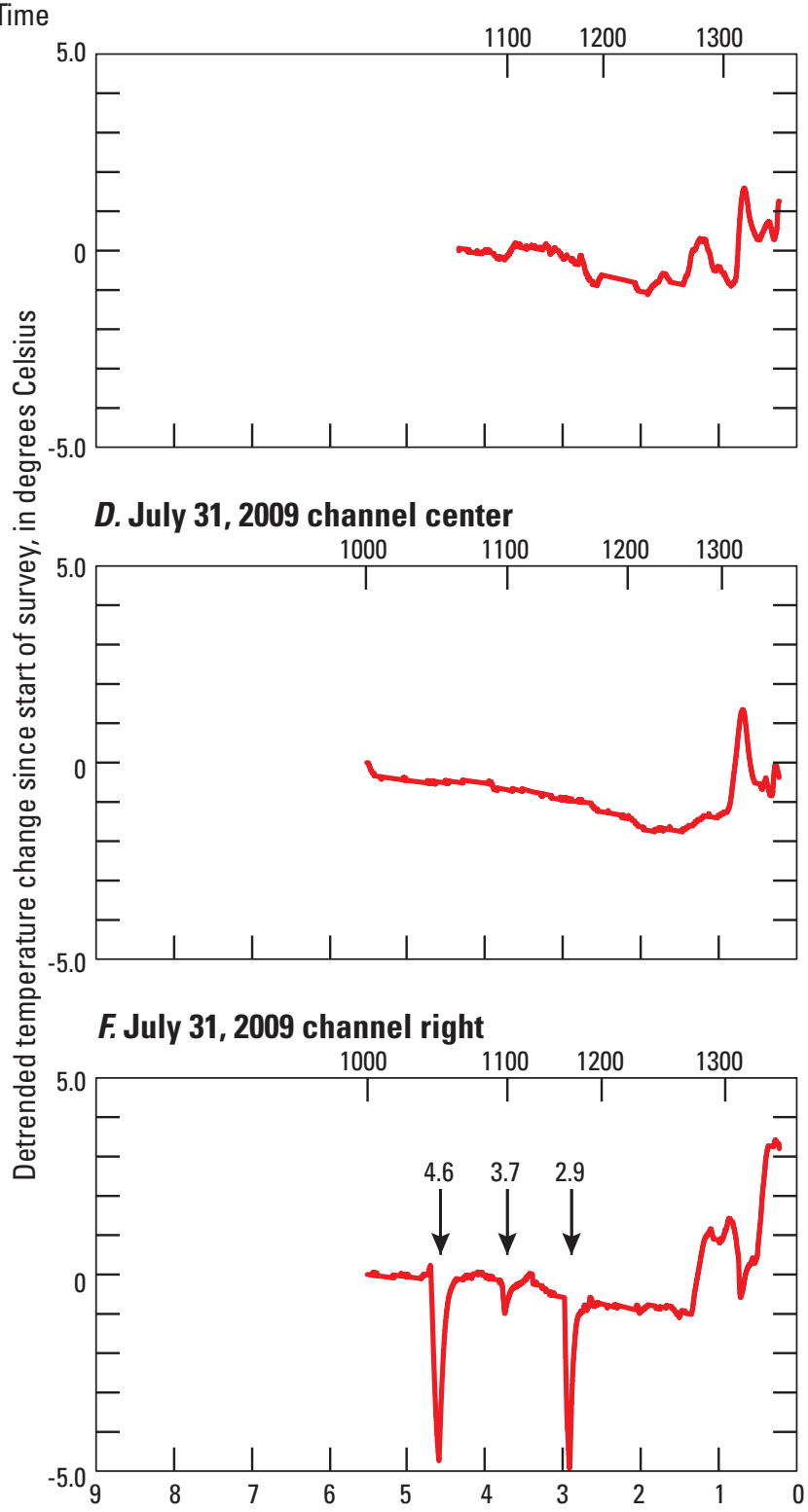

River mile

\section{EXPLANATION}

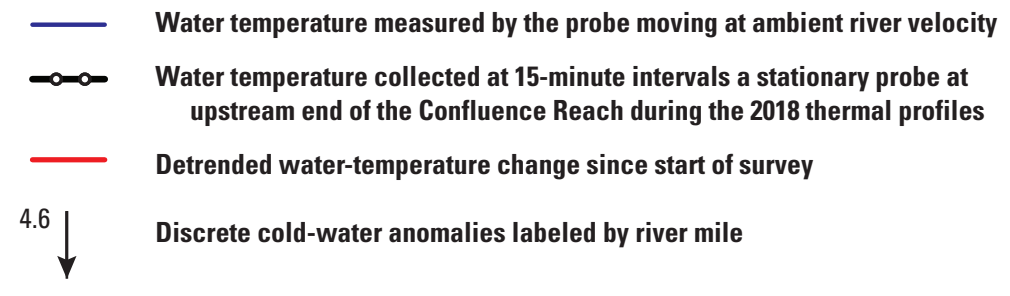

Figure 32. Thermal profiles and detrended temperature change, since the start of survey, of channel left $(A$ and $B)$, channel center $(C$ and $D)$, and channel right, Confluence Reach, Yakima River, Washington, July 31, 2009. 


\section{A. July 20, 2018 channel right}

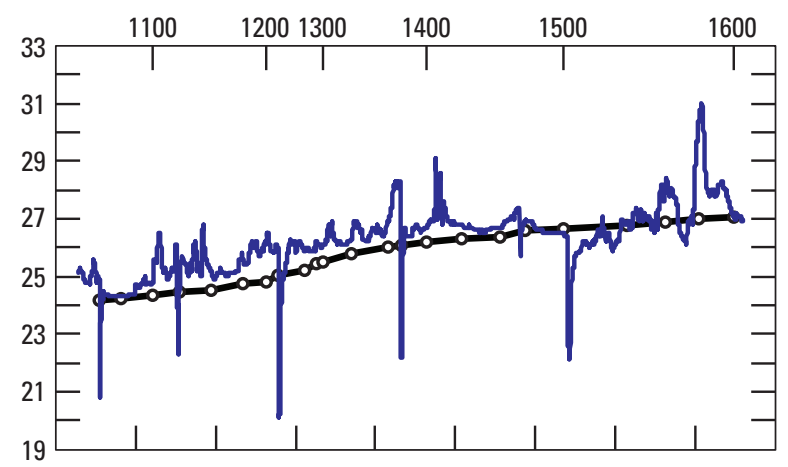

C. July 20, 2018 channel center

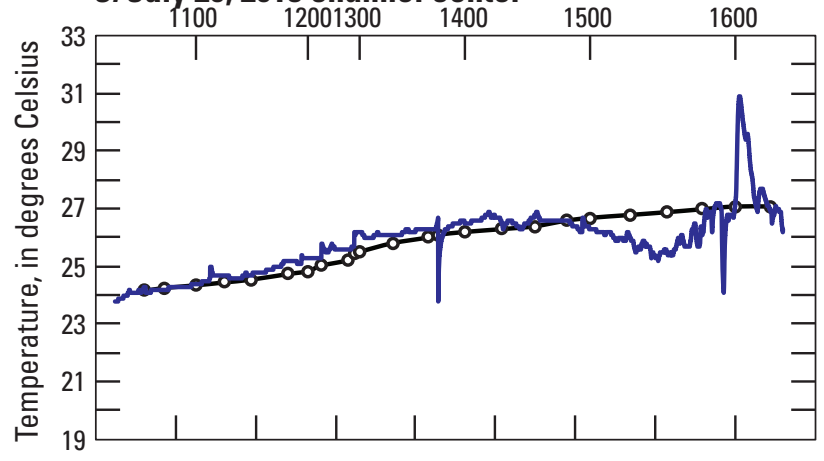

E. July 20, 2018 channel left

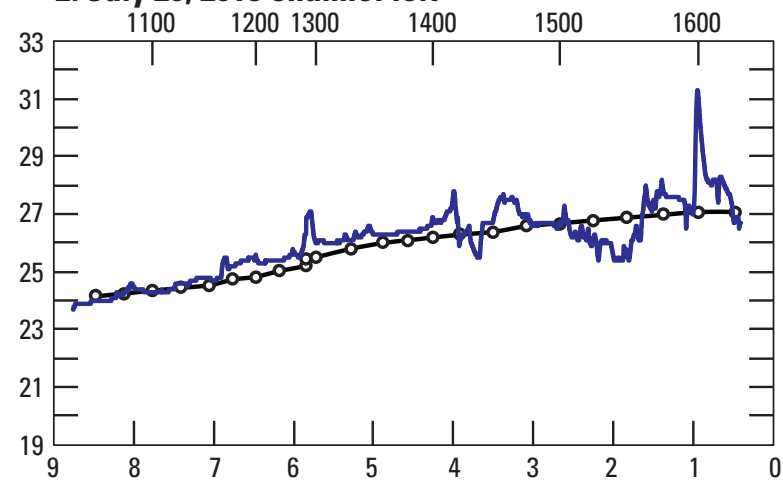

\section{B. July 20, 2018 channel right}
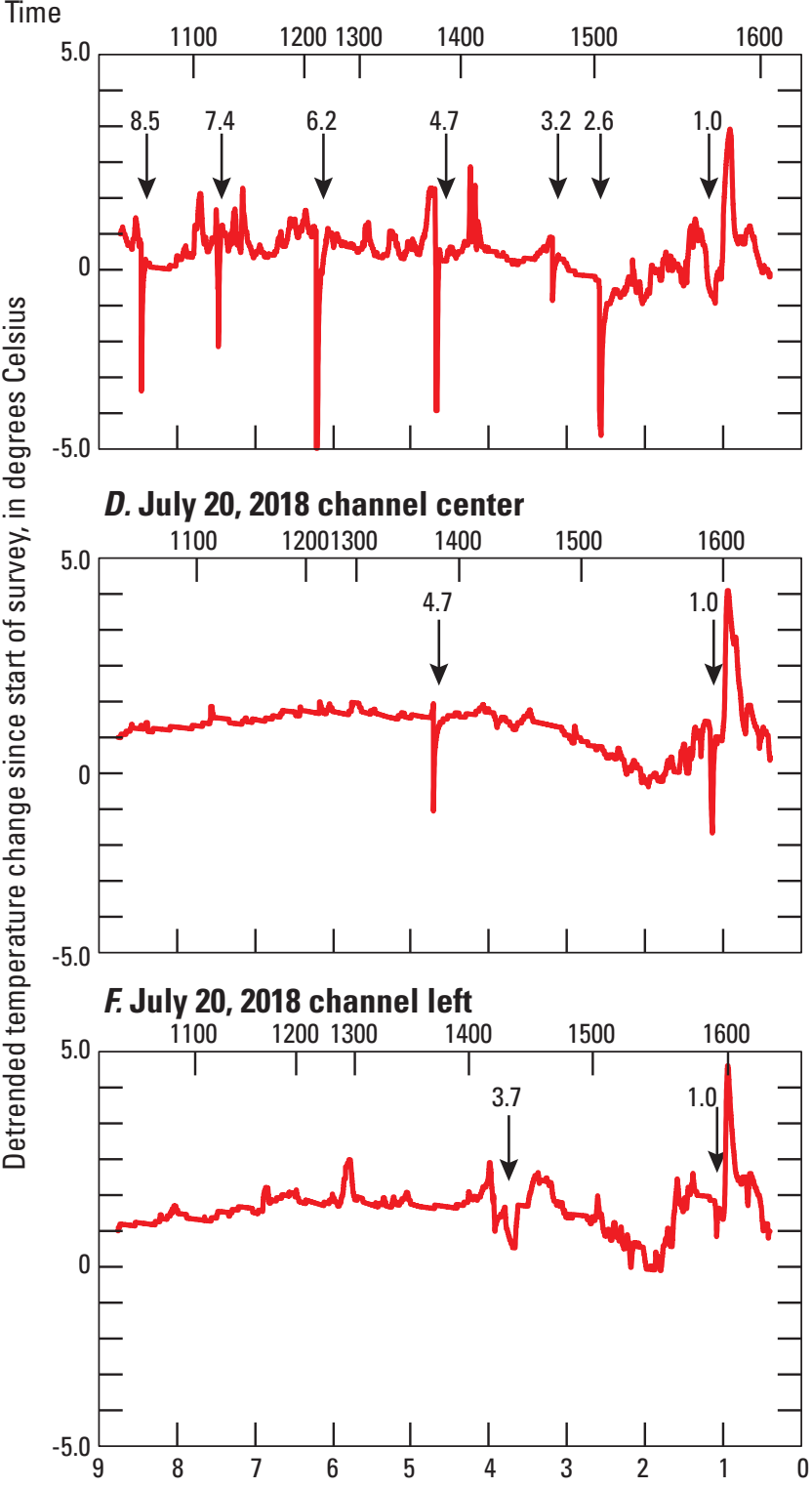

River mile

\section{EXPLANATION}

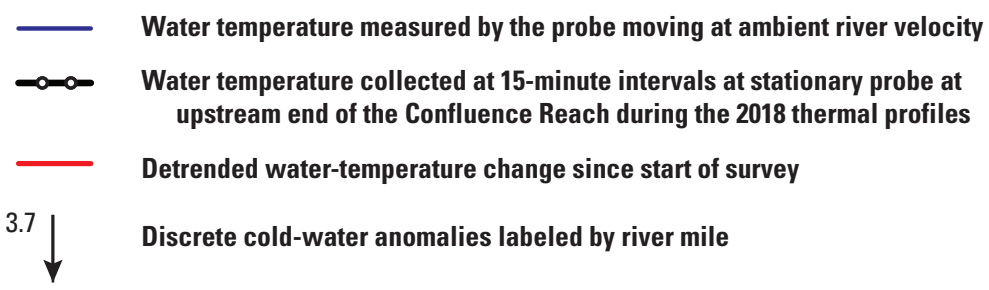

Figure 33. Thermal profiles and detrended temperature change, since the start of survey, of channel right $(A$ and $B)$, channel center ( $C$ and $D)$, and channel left ( $E$ and $F$, Confluence Reach, Yakima River, Washington, July 20, 2018. 


\section{Discussion}

Advective heat fluxes to the lower Yakima River, which include groundwater discharge and tributary inputs, are important components of the river's heat budget that determine the occurrence and magnitude of cold-water anomalies that deviate from ambient water temperatures. Groundwater discharge, which is cooler than surface water during the summer, enters the Yakima River through the streambed, springs, and seeps as well as tributaries and irrigation returns that convey groundwater discharge to the Yakima River. Due to changes in hydrologic conditions including streamflow and groundwater recharge from precipitation and irrigation, groundwater/surface-water exchanges vary in time and space. These exchanges reflect the complexity of the Yakima River's floodplain, channel, and groundwater-flow system (Vaccaro, 2011). Additionally, a complex network of dams, reservoirs, canals, and wasteways that were developed to convey irrigation water for agriculture within the Yakima Valley fundamentally altered the spatial and temporal distribution of recharge to surficial aquifers and groundwater discharge to the Yakima River. As a result of irrigation within the Yakima Valley, most groundwater discharge to the Yakima River within the study area originated, particularly during the summer irrigation season, as surface-water irrigation as evidenced by its stable isotope signature (Vaccaro, 2011).

Some cold-water anomalies within the lower Yakima River were present in all years of the thermal profile surveys, whereas others were not. This pattern of anomalies may reflect temporal changes in hydrologic conditions in the river and its relation to underlying hydrogeologic units created by changes in streamflow of the Yakima River as well as changes in recharge due to seasonal and interannual variation of the irrigation water application and precipitation. These temporal differences are also reflected in changes in streamflow gains and losses net of surface-water inflows and diversions in the lower Yakima River compiled by Magirl and others (2009). Additionally, differences in the relative temperature between groundwater and surface water may have enhanced or diminished the magnitude and extent of cold-water anomalies measured during thermal profile surveys. For example, within the Prosser Reach, the 2009 profile was surveyed in July when surface-water temperatures were greater than other surveys in late August or early September. Some cold-water anomalies that were present in July 2009 were not present during August and September of the other years of surveys. The lateral extent of sampling may have also contributed to the detection of cold-water anomalies in some surveys but not in others because some cold-water patches were restricted to particular features such as bank seeps, outlets of secondary channels, or alcoves at the downstream end of point bars that may have been missed by the center profile.

At the valley scale, several hydrogeologic and geomorphic features create the hydraulic conditions for groundwater/ surface-water exchanges. These features include longitudinal changes in aquifer thickness and extent, permeability contrasts in hydrogeologic units, channel forms that increase the hydraulic gradient between surface water and groundwater or the cross-sectional area of the channel that intersect groundwater flow paths, and other factors that define the relation between a river and its underlying aquifer (Konrad, 2006). For example, thinning of the basin-fill sediments occurs at the margins of the Benton basin (Jones and others, 2006) near the upstream end of the Prosser Reach at RM 47. Detrended thermal profiles of parts of the Prosser Reach were less than the start of the profile, which is consistent with the thinning of underlying aquifers within the basin-fill sediments and the discharge of groundwater recorded by seepage runs within this reach. In addition to longitudinal changes in aquifer thickness, a break in the longitudinal profile and an increase in watersurface gradient of the Yakima River at the Prosser diversion dam creates a hydraulic gradient conducive to groundwater discharge from underlying aquifers to the river. By contrast, diffuse groundwater seepage is not recorded in the Mabton Reach, which is located at the upstream end of the Benton basin, where the underlying aquifer thickens in the downstream direction. The potential for hydraulic gradient between groundwater and surface water was minimized within the Mabton Reach, which had the lowest water-surface gradient of the nine study reaches further reducing the potential for riveraquifer exchange.

Groundwater gradients and flow paths in unconsolidated and bedrock aquifers vary spatially throughout the study area in response to the spatial distribution of groundwater recharge and the distribution of hydrogeologic units (Vaccaro and others, 2009). Within the Parker, Toppenish, and Granger Reaches between RM 103 and 74, the Yakima River flows along the northern margin of the Yakima Valley where the river is generally oriented perpendicular to groundwater flow paths delineated by Vaccaro and others (2009) such that the left bank of the Yakima River intercepts groundwater from the adjacent uplands of the Yakima Valley as diffuse seepage as well as discrete springs located at the base of terraces on the left bank (for example, RM 79.8). In addition to direct groundwater seepage to the left bank of the northern margin of the Yakima Valley, groundwater discharges to irrigation returns such as the Sulphur Creek Wasteway, which forms a large cold-water anomaly at RM 61.0 within the Mabton Reach in which cold-water anomalies are largely absent otherwise. Downstream of the Prosser diversion dam, steep groundwater gradients within both the basin-fill aquifers and underlying basalt bedrock aquifers result in direct groundwater discharge into the Yakima River, which results in numerous cold-water anomalies measured within the Prosser Reach to the Confluence Reach. An exception occurs within the Benton Reach and the Snively Reach where the Yakima River flows over the relatively porous basalt of the Saddle Mountains Basalt in which groundwater levels were mapped by Vaccaro and others (2009) to be below the streambed resulting in streamflow losses documented by Magirl and others (2009) from RM 29.9 to 8.4. Several cold-water anomalies, however, do occur in these reaches (figs. 24-26, 28-30), which may be 
the result of irrigation in the riparian upland and losses from irrigation canal leakage. Cold-water anomalies within the Snively and Confluence Reaches generally occur along the right bank, which is consistent with generalized groundwater flow paths from the south interpreted by Vaccaro and others (2009) within both basin-fill aquifers and bedrock aquifers of the Saddle Mountains Basalt. To the north of the Snively and Confluence Reaches, groundwater flow paths are oriented to the east and are therefore not intercepted by the left bank of the Yakima River within the Snively and Confluence Reaches.

In addition to hydrogeologic controls, geomorphic controls such as channel gradient and floodplain morphology contribute to groundwater/surface-water exchange and the creation of cold-water anomalies observed within thermal profiles. In the wide floodplains of the Parker, Toppenish, and Granger Reaches, frequent channel migration creates planform fluvial features revealed by relative elevation model surface model maps (for example, fig 5). Features within the floodplains and channels of these reaches including side channels, spring brooks, deep pools, and gravel bars and alcoves, create conditions within the channel conducive to groundwater discharge and prevent such discharge from mixing with warmer water upstream. At the start of the Toppenish Reach at RM 91, for example, a cold-water anomaly was measured during the 2018 survey at the outlet of a spring brook. In 2001, the location of this spring brook was the primary channel of the Yakima River and no cold-water anomaly was present. This observation suggests that groundwater emerging within the spring brook may be following the subsurface path of the former path of the Yakima River's channel as it existed in 2001 and allowed to discharge before mixing with water conveyed from upstream. Similarly, several cold-water features (for example, at RM 103.0 and 95.4 within the Parker Reach, fig. 11) were measured within alcoves at the downstream end of gravel bars where groundwater discharge remained cold because it did not readily mix with warmer water from upstream. Channel changes that resulted in the scour of pools (for example, RM 76.7 within the Granger Reach) also contributed to the formation of cold-water anomalies due to lowering of the streambed below the water-table elevation and the potential for increased thermal stratification within the pool. Planform geomorphic features that were conducive to groundwater discharge were abundant within the wide floodplain of the Parker, Toppenish, and Granger Reaches. In the predominantly stable and single-threaded channels within narrow floodplains downstream (figs. 6, 7), side channels and alcoves created the conditions for several cold-water anomalies that were surveyed. For example, a discrete cold-water anomaly at RM 4.7 in the Confluence Reach measured across multiple years of thermal profiles received cold groundwater discharge and was largely limited to the right side of the channel where the groundwater discharge occurred.

Identification of the location and temporal stability of cold-water anomalies is a first step in understanding thermal complexity in the lower Yakima River and how it supports habitat for aquatic biota. Further investigations are warranted to determine the suitability and function of individual coldwater anomalies identified within this report as cold-water refuges for salmonids and other fish. Information about the location of spawning and spawning fish in relation to these cold-water anomalies could help managers understand their function and relative importance as cold-water refuges in the lower Yakima River. The quality of physical habitat for fish during various life-history stages was not assessed within this report; however, the prioritization of habitat restoration projects could be informed by determining where thermally suitable conditions exist, but physical structure is absent. Additionally, these surveys delineated cold-water anomalies during discrete periods of time, but intra-annual variability of individual cold-water anomalies is largely unknown. Therefore, monitoring of changes in the magnitude and extent of cold-water refuges would be beneficial to understanding their function and importance.

\section{Summary}

Longitudinal thermal profiles of nine reaches in the lower Yakima River revealed the distribution of discrete and diffuse cold-water anomalies created and maintained by hydrogeologic, geomorphic, and hydrologic conditions in the Yakima River's channel, its floodplain, and the adjacent uplands. Hydrogeologic conditions documented by previous investigations, including groundwater-flow directions and changes in the lateral and vertical extent of hydrogeologic units, contributed to diffuse zones of groundwater discharge as basin-fill aquifers thinned such as at the downstream end of the Granger Reach as well as throughout the Prosser and Chandler Reaches, a finding consistent with previous seepage runs. Cold-water anomalies measured at many of these areas are consistent with groundwater discharge. Within the Mabton Reach, by contrast, basin-fill aquifers thicken downstream contributing to seepage losses and the absence of diffuse groundwater discharge. Nevertheless, even within reaches like the Mabton Reach, where groundwater gains are largely absent, cold-water anomalies occur in discrete areas associated with several irrigation returns that collect discharging groundwater that originated from irrigation recharge. Geomorphic conditions, including channel and floodplain complexity, also contribute to the occurrence of cold-water anomalies by lowering the streambed below the water table enabling groundwater discharge to spring brooks within the floodplain that occupy abandoned channels and deep pools scoured within alluvium. Some previously delineated coldwater anomalies were also measured in 2018 during this study, but others were not remeasured because of channel migration or because they were obscured by seasonal changes in the relative differences between groundwater and surface-water temperatures; however, channel migration also contributed to the formation of features, like the scouring of deep pools, where cold-water anomalies were measured for the first time in 2018. 
Collectively, interactions between Yakima River, underlying aquifers, and a complex irrigation network within the Yakima Valley comprised of canals, wasteways, and diversions form important controls on the temperature of the lower Yakima River and the occurrence of cold-water anomalies. Further investigations are needed to understand the function of these cold-water anomalies as cold-water refuges for migrating, spawning, and resident fish within the lower Yakima River.

\section{Acknowledgments}

The study presented in this report was jointly funded by the U.S. Geological Survey using Cooperative Matching Funds (CMF) and a grant to the Benton Conservation District from the Washington Department of Ecology (WRYBPVER1-BentCD-00004) as part of the Yakima Basin Integrated Plan. The authors would like to thank the project partners that collected 2018 thermal profiling data, including: Mark Nielson, Rachel Little, Melissa Pierce (Benton Conservation District); Tom Elliott, Danielle Squeochs, Donald Kishwalk, Hoda Sondossi, Cyrus Dick, Marlin Colfax (Yakama Nation); Alex Conley (Yakima Basin Fish and Wildlife Recovery Board); Jim Carroll, Evan Newell, Amy Cook, Chris Perra (Washington Department of Ecology); Konrad Kauer, Holly Kress (Benton County Noxious Weed Board); Sean Gross (National Oceanographic and Atmospheric Administration); Pat Monk (Bureau of Reclamation); Rebecca Wassell, Conner Parish (Mid-Columbia Fisheries Habitat Enhancement Group); and Amy Fishburn, Jim Loomis, and Karen Wieda (private citizens of Benton County).

\section{References Cited}

Appel, M., 2011, Assessment of the Lower Yakima River in Benton County: Washington, The Benton Conservation District, 166 p.

Bentley, R.D., and Campbell, N.P., 1983, Geologic map of the Yakima quadrangle, Washington: Washington Division of Geology and Earth Resources Geologic Map GM-29, 1 sheet, scale 1:62,500.

Bilby, R.E., 1984, Characteristics and frequency of coolwater areas in a western Washington stream: Journal of Freshwater Ecology, v. 2, no. 6, p. 593-602.

Berman, C.H., and Quinn, T.P., 1991, Behavioral thermoregulation and homing by spring chinook salmon, Oncorhynchus tshawytscha (Walbaum), in the Yakima River: Journal of Fish Biology, v. 39, no. 3, p. 301-312.
Bureau of Reclamation, 1999, Yakima River basin water enhancement project, Washington-Final programmatic environmental impact statement-U.S. Department of Interior, Bureau of Reclamation, Pacific Northwest Region: Yakima, Washington, Upper Columbia Area Office, 197 p.

Burns, E.R., Zhu, Y., Zhan, H., Manga, M., Williams, C.F., Ingebritsen, S.E., and Dunham, J.B., 2017, Thermal effect of climate change on groundwater-fed ecosystems: Water Resources Research, v. 53, no. 4, p. 3341-3351.

Campbell, N.P., 1983, Correlation of late Cenozoic gravel deposits along the Yakima River drainage from Ellensburg to Richland, Washington: Northwest Science, v. 57, p. 179-193.

Drost, B.W., Cox, S.E., and Schurr, K.M., 1997, Changes in ground-water levels and ground-water budgets, from predevelopment to 1986, in parts of the Pasco basin, Washington: U.S. Geological Survey Water-Resources Investigations Report 96-4086, 172 p.

Ebersole, J.L., Liss, W.J., and Frissell, C.A., 2003, Cold water patches in warm streams - Physicochemical characteristics and the influence of shading: Journal of the American Water Resources Association, v. 39, no. 2, p. 355-368.

Environmental Protection Agency, 2003, Environmental Protection Agency Region 10 guidance for Pacific Northwest state and tribal temperature water quality standards: U.S. Environmental Protection Agency, EPA 910 B-03-002, accessed March 10, 2021, at https://nepi s.epa.gov/Exe/ZyPURL.cgi?Dockey=P1004IUI.TXT.

Gendaszek, A.S., Magirl, C.S., and Czuba, C.R., 2012, Geomorphic response to flow regulation and channel and floodplain alteration in the gravel-bedded Cedar River, Washington, USA: Geomorphology, v. 179, p. 258-268.

Gendaszek, A.S., Appel, M., and Sheibley, R.W, 2020, 2018 longitudinal water temperature profiles of the Yakima River, Washington: U.S. Geological Survey data release, https://doi.org/10.5066/P9YCIA50.

Holroyd, E.W., 1998, Analysis of the thermal mapping data for the lower Yakima River: U.S. Department of Interior, Bureau of Reclamation Technical Memorandum No. 8260-98-10, 53 p.

Isaak, D.J., Luce, C.H., Rieman, B.E., Nagel, D.E., Peterson, E.E., Horan, D.L., Parkes, S., and Chandler, G.L., 2010, Effects of climate change and wildfire on stream temperatures and salmonid thermal habitat in a mountain river network: Ecological Applications, v. 20, no. 5, p. 1350-1371.

Jones, J.L., 2006, Side channel mapping and fish habitat suitability analysis using LiDAR topography and orthophotography: Photogrammetric Engineering and Remote Sensing, v. 71, p. 1202-1206. 
Jones, M.A., Vaccaro, J.J., and Watkins, A.M., 2006, Hydrogeologic framework of sedimentary deposits in six structural basins, Yakima River Basin, Washington: U.S. Geological Survey Scientific Investigations Report 2006-5116, 24 p.

Keefer, M.L., Clabough, T.S., Jepson, M.A., Johnson, E.L., Peery, C.A., and Caudill, C.C., 2018, Thermal exposure of adult Chinook salmon and steelhead-Diverse behavioral strategies in a large and warming river system: PLoS One, v. 13 , no. 9 , p. e0204274.

Kock, T.J., Evans, S.D., Hansen, A.C., Ekstrom, B.K., Visser, R., Saluskin, B., and Hoffarth, P., 2020, Evaluation of water temperature effects on adult sockeye salmon (Oncorhynchus nerka) behavior in the Yakima River, Washington, 2019: U.S. Geological Survey Open-File Report 2020-1033, 15 p., accessed September 28, 2020, https://doi.org/10.3133/ ofr20201033.

Konrad, C.P., 2006, Location and timing of river-aquifer exchanges in six tributaries to the Columbia River in the Pacific Northwest of the United States: Journal of Hydrology (Amsterdam), v. 329, no. 3-4, p. 444-460.

Kurylyk, B.L., MacQuarrie, K.T., Linnansaari, T., Cunjak, R.A., and Curry, R.A., 2015, Preserving, augmenting, and creating cold-water thermal refugia in riversConcepts derived from research on the Miramichi River, New Brunswick (Canada): Ecohydrology, v. 8, no. 6, p. 1095-1108.

Lauer, J.W., Echterling, C., Lenhart, C., Belmont, P., and Rausch, R., 2017, Air-photo based change in channel width in the Minnesota River basin-Modes of adjustment and implications for sediment budget: Geomorphology, v. 297, p. 170-184.

Magirl, C.S., Webb, R.H., and Griffiths, P.G., 2005, Changes in the water surface profile of the Colorado River in Grand Canyon, Arizona, between 1923 and 2000: Water Resources Research, v. 41, no. 5, W05021.

Magirl, C.S., Julich, R.J., Welch, W.B., Curran, C.R., Mastin, M.C., and Vaccaro, J.J., 2009, Summary of seepage investigations in the Yakima River basin, Washington: U.S. Geological Survey Data Series 473.

Mastin, M.C., 2008, Effects of potential future warming on runoff in the Yakima River Basin, Washington: U.S. Geological Survey Scientific Investigations Report 2008-5124, 12 p.

McCullough, D.A., 1999, A review and synthesis of effects of alterations to the water temperature regime on freshwater life stages of salmonids, with special reference to Chinook salmon: U.S Environmental Protection Agency, EPA 910-R-99-010, 279 p.
Nielsen, J.L., Lisle, T.E., and Ozaki, V., 1994, Thermally stratified pools and their use by steelhead in northern California streams: Transactions of the American Fisheries Society, v. 123 , no. 4 , p. 613-626.

Oregon Department of Geology and Mineral Industries, 2016, Oregon Lidar consortium Yakima-Benton, collected between May 10 and June 12, 2015, by Quantum Spatial, Inc., one-meter resolution: Oregon Department of Geology and Mineral Industries, accessed February 2, 2021, at http://lidarportal.dnr.wa.gov.

Poole, G.C., Stanford, J.A., Running, S.W., and Frissell, C.A., 2006, Multiscale geomorphic drivers of groundwater flow paths - Subsurface hydrologic dynamics and hyporheic habitat diversity: Journal of the North American Benthological Society, v. 25, no. 2, p. 288-303.

Spatial, Q., Inc., 2021, Lower Yakima River - Thermal Infrared Airborne Imagery - Technical Data Report: Pasco, Washington, Benton Conservation District, 47 p.

Reidel, S.P., and Fecht, K.R., 1994, Geologic map of the Richland 1:100,000 quadrangle, Washington: Washington Division of Geology and Earth Resources, Open-File Report 94-8, 21 p., 1 sheet, scale 1:100,000.

Schuster, J.E., compiler, 1994, Geologic map of the east half of the Yakima 1:100,000 quadrangle, Washington: Washington Division of Geology and Earth Resources Open File Report 94-12, 19 p., 1 plate.

Smith, G.A., 1988, Sedimentology of proximal to distal volcaniclastics dispersed across an active foldbeltEllensburg Formation (late Miocene), central Washington: Sedimentology, v. 35, no. 6, p. 953-977.

Snyder, E.B., and Stanford, J.A., 2001, Review and synthesis of river ecological studies in the Yakima River, Washington, with emphasis on flow and salmon interactions-Final report: Yakima, Washington, U.S. Bureau of Reclamation, August 21, 2001, revised September 20, 2001, 118 p., 1 app.

Stanford, J.A., Snyder, E.B., Lorang, M.N., Whited, D.C., Matson, P.L., and Chaffin, J.L., 2002, The reaches projectEcological and geomorphic studies supporting normative flows in the Yakima River basin, Washington: Flathead Lake Biological Station, University of Montana, Final Report to Bureau of Reclamation, Yakima Office, Yakima, Washington, $152 \mathrm{p}$.

Sutton, R.J., Deas, M.L., Tanaka, S.K., Soto, T., and Corum, R.A., 2007, Salmonid observations at a Klamath River thermal refuge under various hydrological and meteorological conditions: River Research and Applications, v. 23, no. 7, p. 775-785. 
Tolan, T.L., Reidel, S.P., Beeson, M.H., Anderson, J.L., Fecht, K.R., and Swanson, D.A., 1989, Revisions to the estimates of the areal extent and volume of the Columbia River Basalt Group, in Reidel, S.P., and Hooper, P.R., eds., Volcanism and tectonism in the Columbia River Flood-Basalt Province: Geological Society of America, v. 239, p. 1-20.

Torgersen, C.E., Price, D.M., Li, H.W., and McIntosh, B.A., 1999, Multiscale thermal refugia and stream habitat associations of Chinook salmon in Northeastern Oregon: Ecological Applications, v. 9, no. 1, p. 301-319.

Torgersen, C.E., Ebersole, J.L., and Keenan, D.M., 2012, Primer for identifying cold-water refuges to protect and restore thermal diversity in riverine landscapes: U.S. Environmental Protection Agency, EPA 910-C-12- 001, 91 p., accessed November 2, 2020, at hhttp://www.epa.gov/ region10/pdf/water/torgersen_etal_2012_cold_water_ refuges.pdf.

U.S. Department of Agriculture, 2012, National Agriculture Imagery Program (NAIP) information sheet: U.S. Department of Agriculture information sheet, accessed December 29, 2020, at https://www.fsa.usda.gov/Internet/ FSA_File/naip_2012_final.pdf.

Vaccaro, J.J., 2011, River-aquifer exchanges in the Yakima River basin, Washington: U.S. Geological Survey Scientific Investigations Report 2011-5026, 98 p.

Vaccaro, J.J., and Maloy, K.J., 2006, A method to thermally profile long river reaches to identify potential areas of ground-water discharge and preferred salmonid habitat: U.S. Geological Survey Scientific Investigations Report 2006-5136, 16 p.
Vaccaro, J.J., and Olsen, T.D., 2007, Estimates of groundwater recharge to the Yakima Basin Aquifer system, Washington, for predevelopment and current land-use and land-cover conditions: U.S. Geological Survey Scientific Investigations Report 2007-5007, 30 p., accessed September 19, 2020, at https://pubs.usgs.gov/sir/ 2007/5007/.

Vaccaro, J.J., Keys, M.E., Julich, R.J., and Welch, W.B., 2008, Thermal profiles for selected river reaches in the Yakima River Basin, Washington: U.S. Geological Survey Data Series 342. [Also available online at https://pubs .usgs.gov/ds/342.]

Vaccaro, J.J., Jones, M.A., Ely, M.D., Keys, M.E., Olsen, T.D., Welch, W.B., and Cox, S.E., 2009, Hydrogeologic framework the Yakima River basin aquifer system, Washington: U.S. Geological Survey Scientific Investigations Report 2009-5152, 106 p.

Voss, F.D., Curran, C.A., and Mastin, M.C., 2008, Modeling water temperature in the Yakima River, Washington, from Roza Diversion Dam to Prosser dam, 2005-06: U.S. Geological Survey Scientific Investigations Report 2008-5070, 42 p.

Voss, F., and Maule, A., 2013, Development of a databasedriven system for simulating water temperature in the lower Yakima River main stem, Washington, for various climate scenarios: U.S. Geological Survey Open-File Report 2013-1010, 20 p. 

Publishing support provided by the U.S. Geological Survey Science Publishing Network, Tacoma Publishing Service Center

For more information concerning the research in this report, contact the Director, Washington Water Science Center

U.S. Geological Survey

934 Broadway, Suite 300

Tacoma, Washington 98402

https://www.usgs.gov/centers/wa-water 


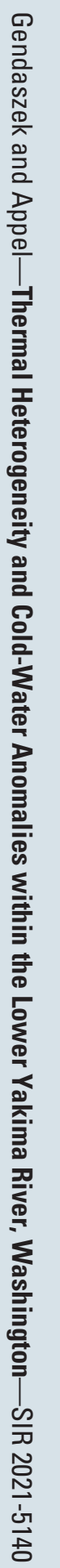

